\title{
Diversity of rice weeds vegetation and its potential as local forage resource in Java, Indonesia
}

\author{
Dissertation \\ for the award of the degree \\ “Doctor rerum naturalium” (Dr.rer.nat.) \\ of the Georg-August-Universität Göttingen
}

within the doctoral program Vegetationsanalyse and Phytodiversität of the Georg-August University School of Science (GAUSS)

submitted by

Nur Rochmah Kumalasari

from Kebumen

Göttingen, 2014 
Thesis Committee:

Prof. Dr. Erwin Bergmeier

Department of Vegetationsanalyse and Phytodiversität

Prof. Dr. Hermann Behling

Department of Palynology and Climate Dynamics

Members of the Examination Board:

Prof. Dr. Christoph Leuschner

Prof. Dr. Markus Hauck

Prof. Dr. Johannes Isselstein

Prof. Dr. Susanne Boegeholz

Date of the oral examination: June 11, 2014 


\section{Summary}

The ecosystems around paddy fields in Java are varied, owing to differences in climate, altitude and traditional farming varies across villages. The main objectives of the present study were 1) to examine the diversity and composition of weed communities in paddy fields and their relation to environmental factors, agricultural practice and cultivation season; 2) to examine the effects of different types of surrounding vegetation on the plant diversity in paddy fields; and 3) to evaluate the productivity and nutrient potential of rice weeds as ruminant feed.

We studied sites in six areas in the island of Java, Indonesia, i.e. Cugenang, Karanganyar, Malang (400-850 m asl), Karawang, Brebes and Gresik (10-50 m asl). Samples of vegetation were taken in a period from October 2011 through to June 2012. Each site comprised 33 plots of paddy fields, $20 \mathrm{~m}^{2}$ in size and bunds $10 \mathrm{~m}^{2}$ in size. The weeds were collected in cultivated paddy fields, fallows and on paddy field bunds.

In this research studies, the peak of rice cultivation in Java is around the wet season between October and February. In the examined 198 paddy field plots we recorded 14 crop species and 221 non-crop plant species (weeds), of which 171 species occurred in paddy fields and 190 on bunds. Poaceae, followed by Asteraceae, were most common. In the mid elevations we found higher mean number of species in each plot. Weed cover and diversity was higher in fallowed plots than cultivated plots. Six plant communities were identified by means of multivariate analysis, with species combinations related to altitude, herbicide application, water level and cultivation season. Elevation and water level gradients were the most important factors controlling species composition in paddy fields.

Weed management corresponds to water seasonality because farmer used water to flood their fields in order to control weed growth. Flooding suppresses the growth of grass and certain broadleaved weeds. In fallows, twice as many species as in cultivated rice fields were found. In contrast, the presence of semi-natural vegetation within short distance had no significant effect on weed species numbers in paddy fields. Altogether, differences in weed species numbers and composition between areas are more pronounced than the effects of local environmental complexity.

Weed biomass in mid elevation areas was largest on bunds as a result of intensive weed control in paddy fields. In the lowlands most weed biomass was on fallows. Fresh weed 
biomass in the first rice growing season (after dry season) yielded 891-2369 g/m². Nutrient content revealed a proportion of crude protein between 11.9-16.6\%, crude fiber between 31.6-39.6\%, and crude fat 0.8-1.1\%.

In conclusion, a high variation in the diversity of weed was found across the studied paddy field types. Mid-elevation paddy field is highly diverse in weeds than lowland paddy field. Results show that altitude as well as water availability may support species richness. Some effects differed between regions correlated with different agricultural management, such as weeding habits, plant cropping and cultivation time. However, environment complexity by semi natural vegetation did not influence weed number in paddy fields. Accordingly, weed biomass and nutrient content, thereby abundance of rice weeds has considerable potential as ruminant feed. Consequently, to conserve and support species diversity and ecological function in paddy field and farming system, we suggest to enhance the integrated farming system included animal husbandry. Further, varied condition of semi natural vegetation, fallows and bunds should maintain to support plant diversity and ecosystem functioning in paddy field. 


\section{Table of Contents}

\section{Chapter 1:}

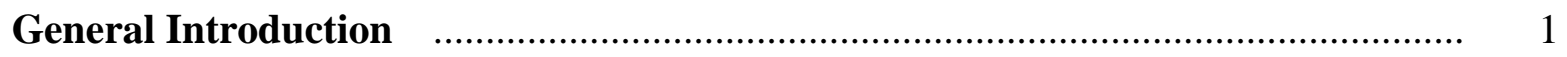

Paddy field ecosystem in Java $\quad$.......................................................................... 2

Rice agriculture and management in Java …......................................................... 3

Weeds problem and management in Java paddy field ......................................... 5

Chapter outline and major hypothesis ................................................................. 8

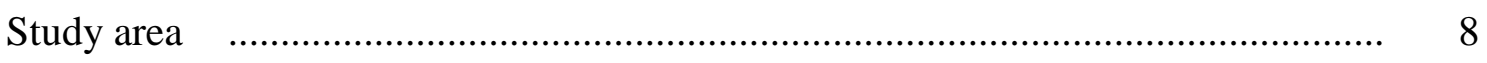

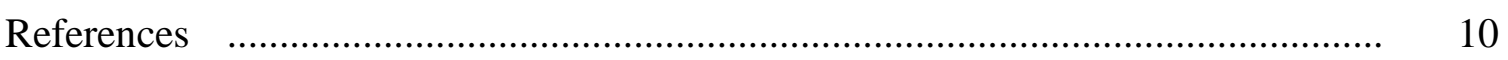

\section{Chapter 2:}

Weed communities of Javanese paddy fields in response to altitude and agronomic

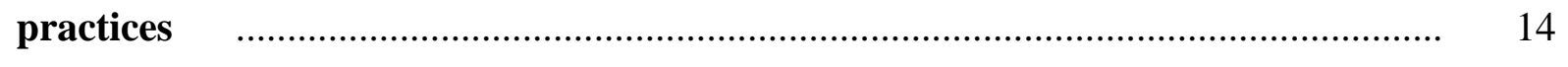

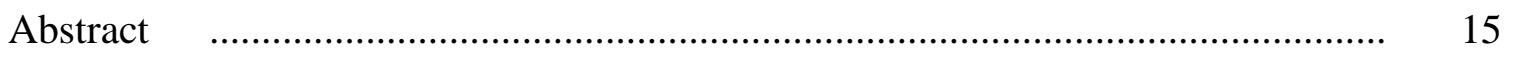

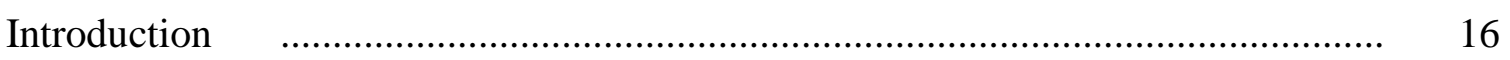

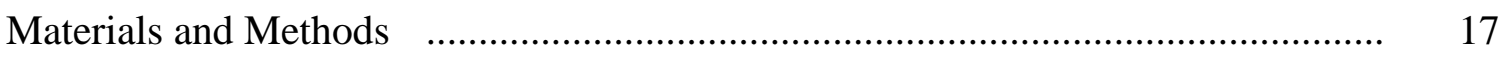

Study area and data acquisition .................................................................... 17

Data analysis ........................................................................................... 19

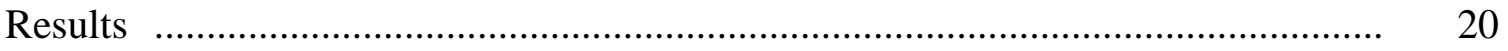

Species richness $\quad$................................................................................... 20

Plant community-environment correlations .................................................. 23

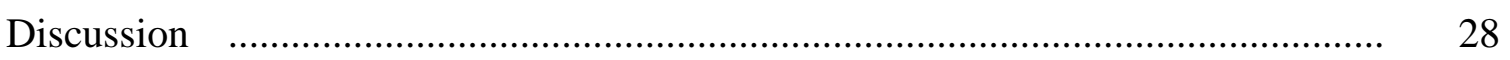

Effects of altitude on weed composition ......................................................... 28

Implication of water management and cultivation status $\quad$................................. 28

Implication of weed management ..................................................................... 29

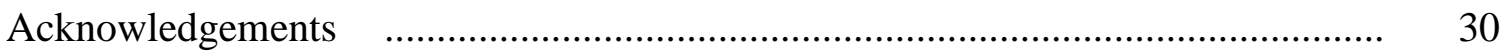

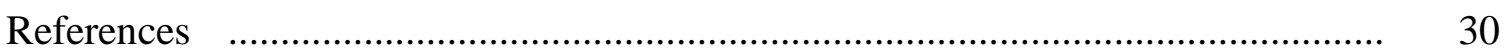




\section{Chapter 3:}

Effects of surrounding crop and semi natural vegetation on the diversity of paddy field weeds

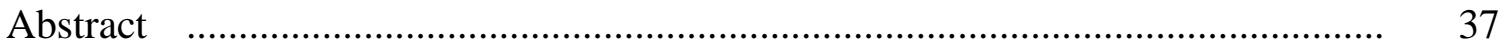

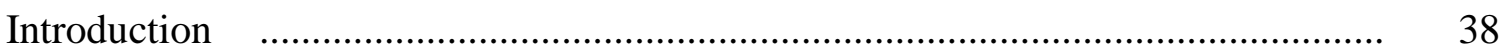

Materials and Methods ...................................................................................... $\quad 39$

Characteristics of sample sites ........................................................................ 39

Data sampling .............................................................................................. 40

Statistical analysis ...................................................................................... 42

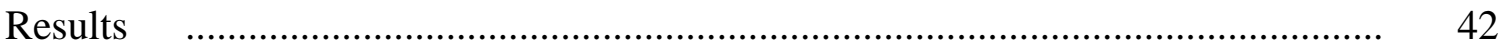

Characteristics of the paddy field environment ............................................. 42

Diversity of weeds in paddy fields and bunds ................................................ 44

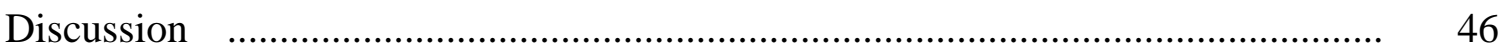

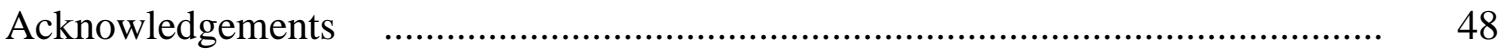

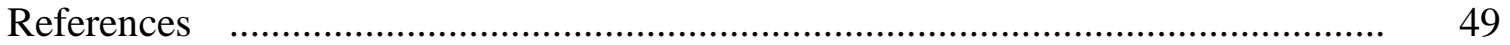

\section{Chapter 4:}

Nutrient assessment of paddy weeds as ruminant feed in Java ............................... 52

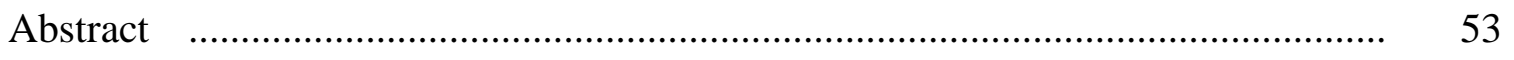

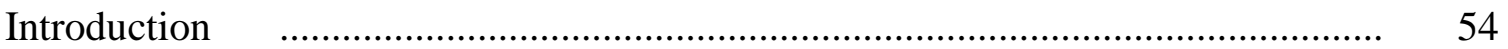

Materials and Methods .................................................................................... 55

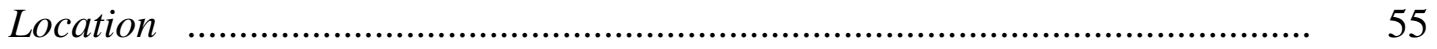

Weed sampling ............................................................................................... 5

Nutrient analysis $\quad$.................................................................................... $\quad 55$

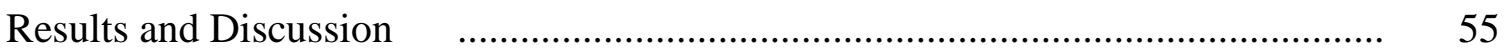

Weed diversity and availability ................................................................... 55

Weed biomass ............................................................................................ 5

Weed nutrient content ................................................................................ 60

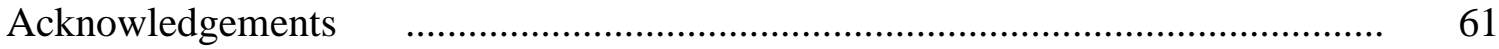

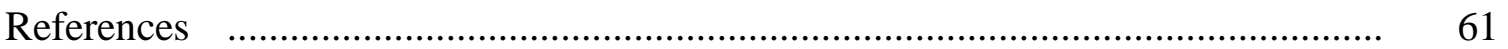




\section{Chapter 5:}

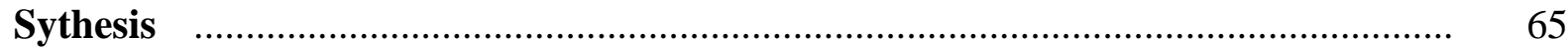

Diversity ecosystem structure and agriculture management in Java paddy field ...... 66

Species diversity in paddy field under varied environment and agronomic practices 66

Species diversity in paddy field under differ surrounding crop and semi natural

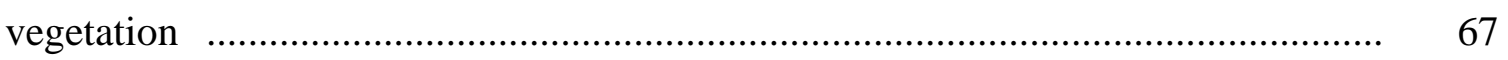

Species diversity an opportunity for the integrated farming system ........................ 67

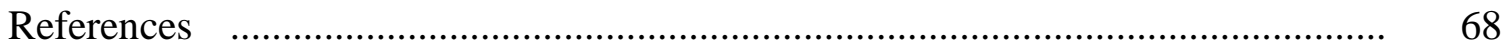

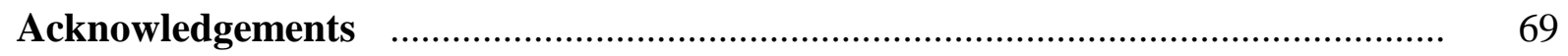

Declaration of originality and certificate of ownership ….................................... 71

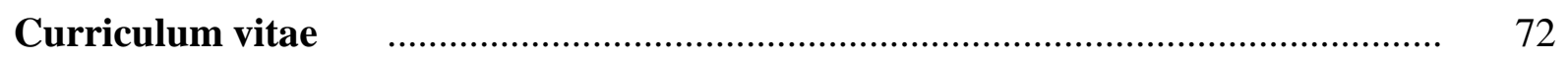




\section{List of Figure}

\section{Chapter 1}

Figure 1 Paddy fields ecosystem in Indonesia (illustrated from Soerjani et al. 1987, adapted figure from IRRI 1993)

Figure 2 Rice growth, agricultural works and water management in different rice cultivation methods (adapted from Maruyama and Tanji, 1997)

Figure 3 Java map

\section{Chapter 2}

Figure 1 The island of Java and the study areas (BPN, 2013)

Figure 2 Mean plant species numbers per plot and standard deviation in mid elevation and lowland cultivated and fallow paddy fields; $\mathrm{nf}$ = number of fallow plots; $\mathrm{nc}=$ number of cultivated plots

Figure 3 Mean plant species numbers in mid elevation and lowland paddy fields with herbicide and without herbicide treatment; $\mathrm{nh}=$ number of plots with herbicide; no = number of plots without herbicide

Figure 4a Nonmetric Multi-Dimensional Scaling (NMDS) ordination showing the classified sample and passively projected environmental factors

Figure 4b Nonmetric Multi-Dimensional Scaling (NMDS) ordination showing scores of 56 selected species; wtrdpth = water depth, cltvnstt = cultivation status, hrbapl = herbicide application, $\mathrm{pH}=$ soil acidity, $\mathrm{P}=$ phosphor content in soil, $\mathrm{K}=$ potassium content in soil, $\mathrm{N}$-Total = total nitrogen content in soil, $\mathrm{C}$-Org = organic $\mathrm{C}$ content in soil; $\boldsymbol{\Delta}$, cluster $1 ; \boldsymbol{\square}$, cluster 2 ; $\diamond$, cluster 3 ; $\bullet$, cluster 4 ; $\nabla$, cluster 5 ; $\times$, cluster 6 Abbreviations of species names are given in Tables 2 and 3. Abbreviated names not found there: Era.amab=Eragrostis amabilis (L) Wight \& Arn; Ses.gran=Sesbania grandiflora (L.) Pers. 


\section{Chapter 3}

Figure 1 Rainfall and temperature mean values in the study areas in 2011 (left y axis and grey line: rainfall in mm; right y axis and black line: temperature

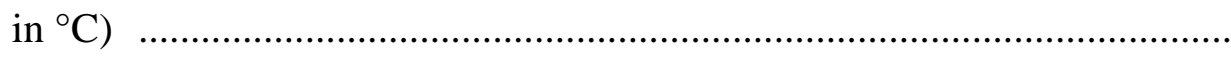

Figure 2 Scheme of bund, terrace and field dimensions of upland (a) and lowland (b) rice fields

Figure 3 Mean $( \pm$ SE) weed species numbers of sample sites, field types, landscape types, bund types, areas and seasons. $\mathrm{Cu}=\mathrm{Cugenang,} \mathrm{Ma}=$ Malang, $\mathrm{Ka}=$ Karanganyar, $\mathrm{Br}=$ Brebes, $\mathrm{Kr}=$ Karawang, $\mathrm{Gr}=\mathrm{Gresik}$ 


\section{List of Table}

\section{Chapter 1}

Table 1 Description of study areas

\section{Chapter 2}

Table 1 Geographic and climatic data regarding the six study areas in the three provinces of West, Central and East Java

Table 2 The most common plant species in fallow and cultivated paddy fields in Java

Table 3 Synoptic table of rice weed communities (plant species constancy, \%).

Differential species of 10-<20\% constancy are highlighted light grey; t highly diagnostic species (20\% or more are highlighted in dark gray

Table 4 Environmental and cultivation characteristics of the six weed communities

\section{Chapter 3}

Table 1 Complexity criteria adopted for paddy fields, bunds and paddy landscape sections

Table 2 Environment types of paddy fields in each area

Table 3 Seasonality of paddy field cultivation in the Javanese study areas

Table 4 Results of the Analysis of Variance Matrix Unbalanced

Table 5 Results of Tukey's HSD test on the weed species numbers in different environments

\section{Chapter 4}

Table 1 Characteristics and composition of weeds in paddy fields

Table 2 Weed taxa encountered as ruminant feed

Table 3 Biomass and nutrient content of weeds in paddy field areas

Table 4 Nutrient content of weeds in the studied paddy field areas on dry matter basis (\%) 


\section{General Introduction}

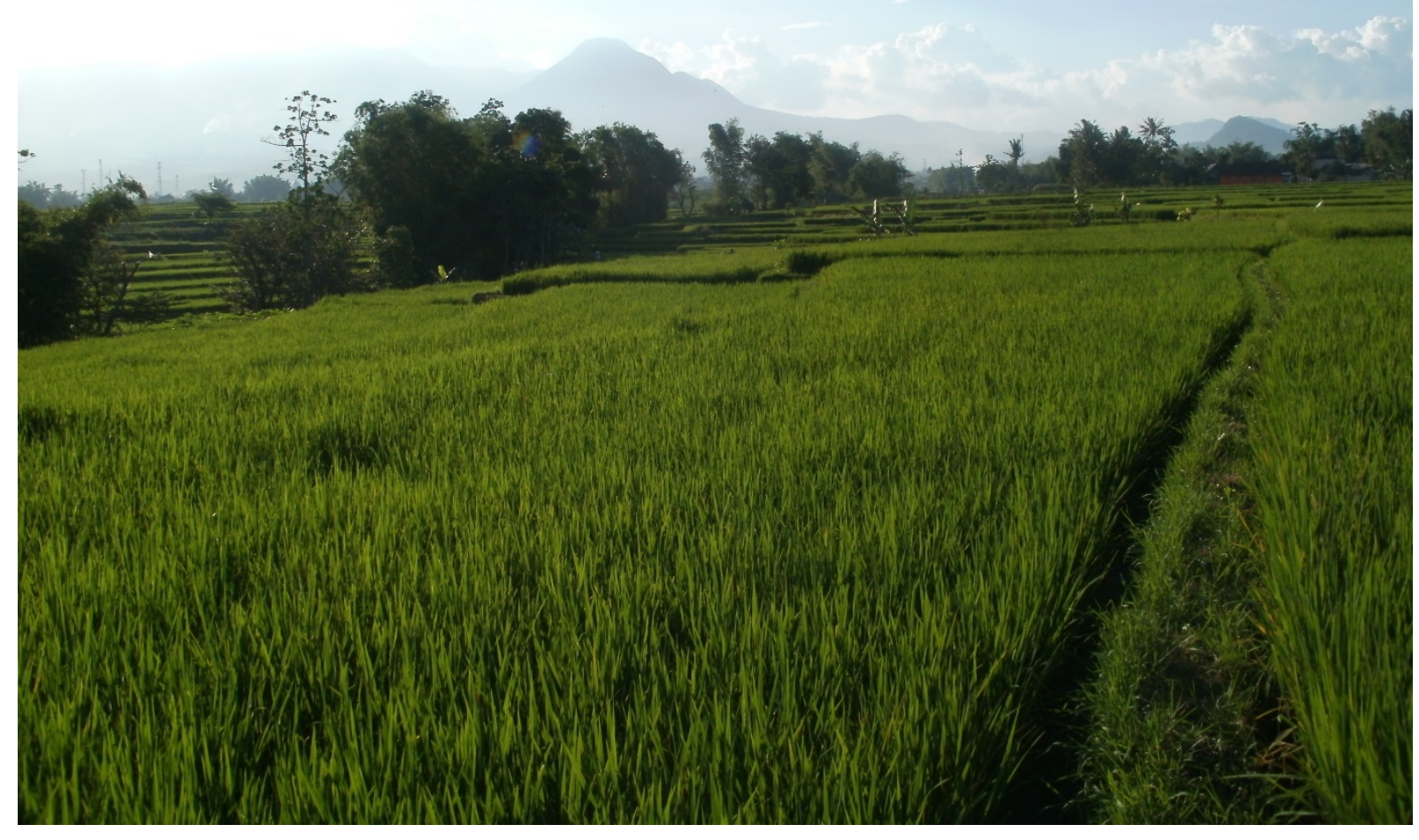




\section{Paddy field ecosystem in Java}

Rice is the staple food in the Indonesian diet, more than half of the total population of Indonesia is almost wholly dependent upon rice. Rice cultivation covers a total of around 11.5 million hectares throughout the archipelago, primarily area on Java around 5.4 million hectares (Bappenas, 2003). Rice can be planted all year round, but a lack of water availability in dry season restricted rice cultivation in some areas, especially in lowland. In the rainy season usually suffices the water requirement.

The systems of rice production and the soil and crop management practices that have been obtained from tradition are complex and unique. There are many factors affecting the rice yield including abiotic ones such as climate, agrohydrology (Boling et al., 2000), soil properties (Harnpichitvitaya et al., 2000), water availability (Fukai, Basyanake and Cooper, 2000), nutrient-fertilizer, and drought risk (Tuong et al., 2000). The supply and control of water are crucial to the productivity of rice land, especially when planted with high-yield seed varieties. In water sufficient fields, numbers of tiller, panicle and rice grain yields were higher than dry fields (Singh et al., 2011). Lu et al. (2000) reported that the intermittent water supply reduces dry matter production and grain yield due to water stress and early senescence.

Soerjani et al. 1987 reported that in Indonesia there are four main rice-growing systems based on water regime (Fig.2). These include (i) irrigated paddy fields, (ii) rainfed paddy fields, (iii) dry paddy fields, and (iv) tidal swamps paddy fields or deep water paddy fields. The irrigated, rain-fed and dry paddy fields were found both in lowland and upland. In 2003 land area for rice production on wet field around 10,5 million hectares that the greatest levels of productivity are found in irrigated paddy fields, where more than one crop is grown per year and yields are high (Bappenas, 2003). On an annual basis, irrigated paddy field is often 100 times more productive than dry paddy field, over 12 times more productive than deep-water paddy fields, and five times more productive than rain-fed paddy fields (Fairhurst and Dobermann, 2002). Irrigated and lowland rain-fed systems account for more than 70 percent of rice production, so small productivity gains have a profound effect on total production. 


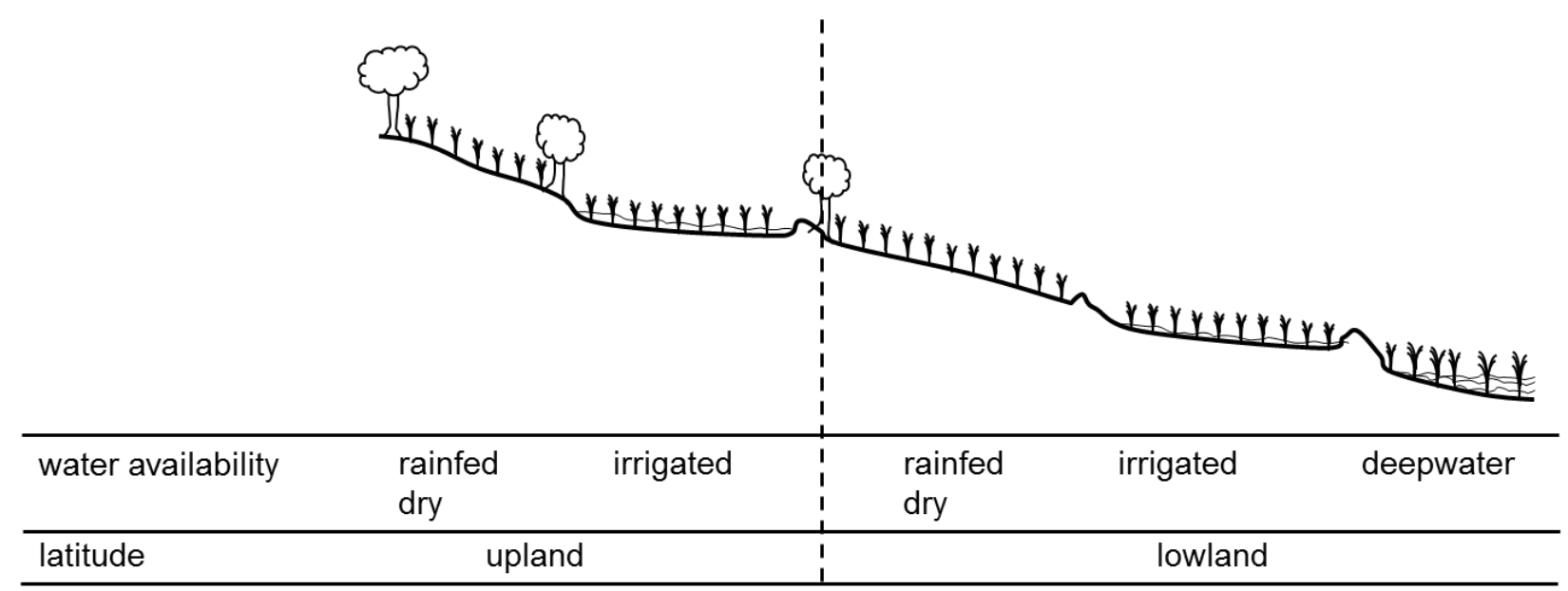

Figure 1 Paddy fields ecosystem in Indonesia (illustrated from Soerjani et al. 1987, adapted figure from IRRI 1993)

In paddy field ecosystems that lives biodiversity form relates to agriculture, includes the diversity of domesticated plants and livestock species, the diversity of wild species and the diversity of ecosystems formed by species population related to different types of agriculture system (Bambaradeniya and Amerasinghe, 2004). Species diversity is important to support agriculture production systems such as soil micro-organisms, earthworms and native plants although some species affected farming activities and can be threaten or be harmful to the systems.

\section{Rice agriculture and management in Java}

The common rice species in Java is Oryza sativa L, belongs to the tribe Oryzeae under the subfamily Pooideae in the grass family Gramineae (Poaceae) (Chang and Bardenas, 1965). The rice plant is generally characterized as a semiaquatic annual grass because rice is adapted in an aquatic habitat. There are three phases of rice plant development, i.e.: vegetative, reproductive and ripening phase. Farmer practice two methods in rice cultivation, i.e. direct seeding and transplanting depend on labor and water availability. The different of rice cultivation methods result the different character on rice plant management (Fig. 1).

Rice cultivation methods affected farmer activities, especially on timeline, main works in paddy field, and water management. Farmer usually practices direct seeding in dry field. The farmer starts to prepare land after rainfall in wet season was enough to moist soil. Farmer prepares paddy field in two steps, harrowing/ploughing and weeds eradicating by herbicide. About one week after herbicide application, farmer sows rice seed on paddy field. 


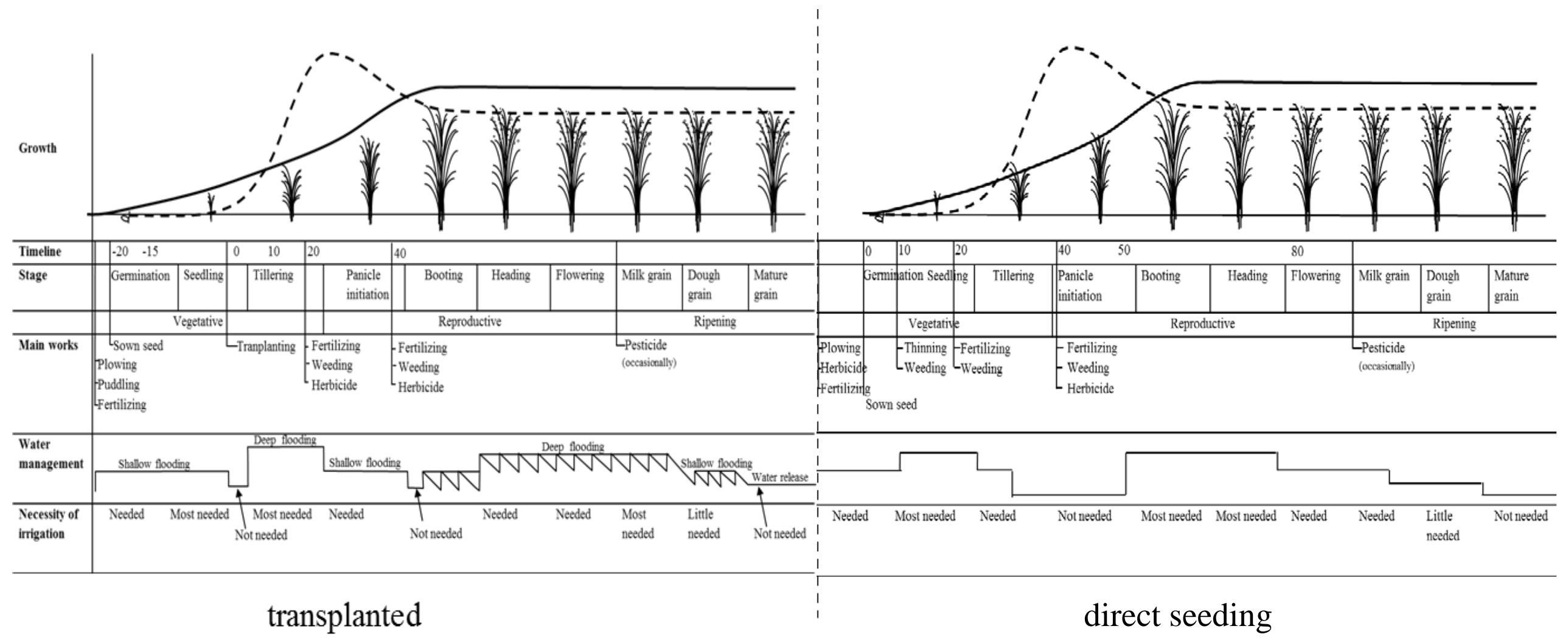

- plant height

runber of tiller

Figure 2 Rice growth, agricultural works and water management in different rice cultivation methods (adapted from Maruyama and Tanji, 1997) 
In transplanted cultivation methods, the main field is prepared under wet conditions. The land preparation consists of soaking, plowing and puddling (harrowing or rotating under shallow submerged conditions) (Sukristiyonubowo, 2007). After puddling, the field usually left fallow and flooded for 1 to 4 weeks before transplanting. In nursery beds, rice is sown and raised until 2-3 weeks old, before subsequently transplanted into the rice field.

\section{Weeds problem and management in Java paddy field}

The biotic factors plays an important role in which weed is the most serious biological constraint to compete rice plant. Weed compete with rice for sunlight, nutrients (Nyarko and Datta, 1993) and water (Pane et al, 2000). Uncontrolled weed presence caused yield loss and moreover can reduce rice quality and grade. Inamura et al (2003) reported that weed competition suppressed $\mathrm{N}$ amount in rice, number of panicle and seeds per square meter. Weed control is an essential component in rice agriculture management. Pane et al (2002) research resulted rice yield loss due to weed around $8-12 \%$ in Karawang. Weed removal increased the amount of $\mathrm{N}$ in rice and rough rice yield until 10\% in rainfed field and $17-19 \%$ under irrigated condition (Inamura et al, 2003). Secondary effects of weeds are numerous and include reduced harvesting and processing efficiency, increased insect and disease severity, and increased production costs (Pane and Jatmiko, 2009).

Crop-weed competition hierarchies are influenced by a host of factors, including planting date, species type, spatial arrangements and relative time of establishment (McDonald, Riha and Ditommaso, 2009). Weeds emerge at about the same time that the rice seeds germinate, and yield losses caused by weeds will become greater with the trend towards wet seeding. Tomita et al. (2003) reported that in Thailand, seasonal changes in dominant weed species in three seasonal patterns of weed infestations, i.e.: infested throughout the rice growing season, the first half of the season, and the second half of the season. Weed cover mostly constant over the season in all field types, although the number of weed species increased in September and decreased in November. Previous study divided weed management practices in Java onto two types, i.e.: indirect and direct methods (Pane and Jatmiko, 2009). Indirect weed control included land preparation, fertilizing technique, rice varieties preference, plant population, plant spacing, cultivation methods, plant rotation and biological control. In land preparation, puddling and rice transplanting decreased many-fold weed densities along rice growth in wet and dry season (Chauhan and Opena, 2012). The addition of organic fertilizer in paddy field significantly increased weed ground cover and 
species richness (Major et al., 2005). Different cultivation method has large impact on weed species composition and diversity especially in wet area (Tomita et al, 2003).

Direct weed control consist of:

Water management methods

Paddy fields use large quantities of water for flooded the area to control weed growth. Flooding is the primary cultural to suppress weeds in irrigated paddy fields because water prevents germination and emergence of weed majority, especially annual grass sedges (Chauhan and Johnson, 2009). In cultivated paddy field, flooding with depth water about 10$15 \mathrm{~cm}$ has been found effective in the control of Echinochloa sp and other hygrophytic weed species (Shibayama, 2001). Weed biomass in flooding paddy field was on average almost a half than dry field (Singh at al., 2011). Other research reported that increasing irrigation frequency was associated with lower diversity of weed seed communities ( $\mathrm{Li}$ and Qiang, 2009).

\section{Manual weeding}

The most common method of manual weeding is remove weeds by handweeding or hoeing. Javanese farmers usually do handweeding twice, first time at 2 to 4 and second at 6 to 7 weeks after transplanting (Pane et al, 2002) or at 21 and 42 days after transplanting (Soekisman, 2010). Baloch et al. (2005) reported that handweeding is more effective method for weed control in Pakistan than flooding. Other research reported that handweeding was effective in reducing yield losses until 16\% (Singh et al., 2011). In lowland area in Java, weed control by handweeding is gradually being replaced by herbicide application due to labor limiting factor and drought environment.

\section{Herbicide application}

The introduction of herbicides has strongly influenced concept and attitude towards weed management. Since 1970s, the importance of mechanical weed control has declined, while there has been increased use of herbicides. Herbicide application time is varied depend on cultivation methods. In transplanting paddy fields, herbicide usually applied on 14 or 21 days after transplanting. Kadir (2007) reported that the best time of herbicide application is around 21 days after transplanting. In direct seeded, herbicide was applied one week before rice seed sown and in some areas farmer applied the second on 40 days after rice cultivation. Herbicide 
application in paddy fields increases rice yield 17-37.7\% (Kadir, 2007; Marpaung et al., 2013).

Weeds have been regarded as a problem that can be controlled with herbicides, rather than managed through cropping systems design. Herbicide resistance can easily lead to an increase in herbicide use because additional herbicides and /or higher doses are required for satisfactory control. When herbicide is applied to control weeds a large proportion of it will end up in the environment, be it soil, water, the atmosphere or in the harvested produce (Kudsk and Streibig, 2003). Chairul et al. (2000) reported that residues of herbicide increases in parts of rice plant time by time and the residues in rice yield was 3.16-4.24 x 10 $0^{-3}$ depends on soil condition. The occurrence of the resistant biotype within a paddy may cause problems to farmers (Itoh et al., 1999).

Herbicide usage to control weed were not always recommended. A recent research reported that herbicide application changed weed composition (Nurjannah, 2003). There are a huge varied composition of dominant or troublesome weed, depend on the habitat. Weed species of Poaceae are the most common in paddy field, followed by Cyperaceae and other broad-leaved families (Soekisman, 2010). A research in Tobelo reported that the predominant weed families are Poaceae, Passifloraceae and Euphorbiaceae (Kastanja, 2011).

Weeds also have several advantages as pest trap. Kartohardjono (2011) reported that Cynodon dactylon, Leersia hexandra, Paspalum vaginalis, Digitaria sp., and Echinocloa gruscalli has potential as pest trap and as a host of planthopper predator Cyrtorhinus. Other weeds species Panicum repens, Paspalum paspoledes, Leersia hexandra, Digitaria sp., and Drymoria villosa has potential as host of parasitoid Anagrus sp. The existences of predator, parasitoid and weeds species as host are important in order to implement biological pest control management. Other rice weed utility is as ruminant feed (Bakrie, 1996). Almost all the feed consumed by ruminants in paddy field comprised of grasses collected from fallow field or bunds.

This research therefore provides an opportunity to address the question as how to environment and rice cultivation management affect the diversity, composition and distribution of weed in paddy field and whether such weed species have potency for ruminant feed. 


\section{Chapter outline and major hypothesis}

\section{Chapter 2}

We surveyed the weed communities and described the species composition and distribution of communities in paddy fields at upland and lowland areas in Java. We also studied the effects of altitudes, herbicide application and water level gradients on weed occurrence in paddy fields during cultivation season.

Our main hypothesis were:

(1) Environment factors determine the variation in plant species composition and richness in paddy fields of Java

(2) Weed management modify plant communities in paddy fields

\section{Chapter 3}

We compared the different number of weed species in paddy field and bunds based on landscape complexity surrounding paddy fields such as semi-natural vegetation, intercropping and multi-cropping.

Our main hypothesis were:

(1) The weed species numbers and composition in paddy fields and bunds differ

(2) The surrounding crops and semi-natural vegetation influence the weed communities

\section{Chapter 4}

We investigated weed potency for ruminant feed in paddy fields and analyzed nutrient contents in weed.

Our main hypothesis were:

(1) Some weed in paddy field have high nutrient value for ruminant feed

(2) The potential weed for ruminant feed may depend on the study area

\section{Study area}

Our research was conducted in six locations in Java Island, Indonesia, i.e.: Cugenang and Karawang in West Java Province; Karanganyar and Brebes in Central Java Province; then Malang and Gresik in East Java Province (Fig. 3). Cugenang, Karanganyar and Malang are representative of upland paddy fields (400-850 masl). Other sites are representative of lowland paddy fields (10-50 masl). 


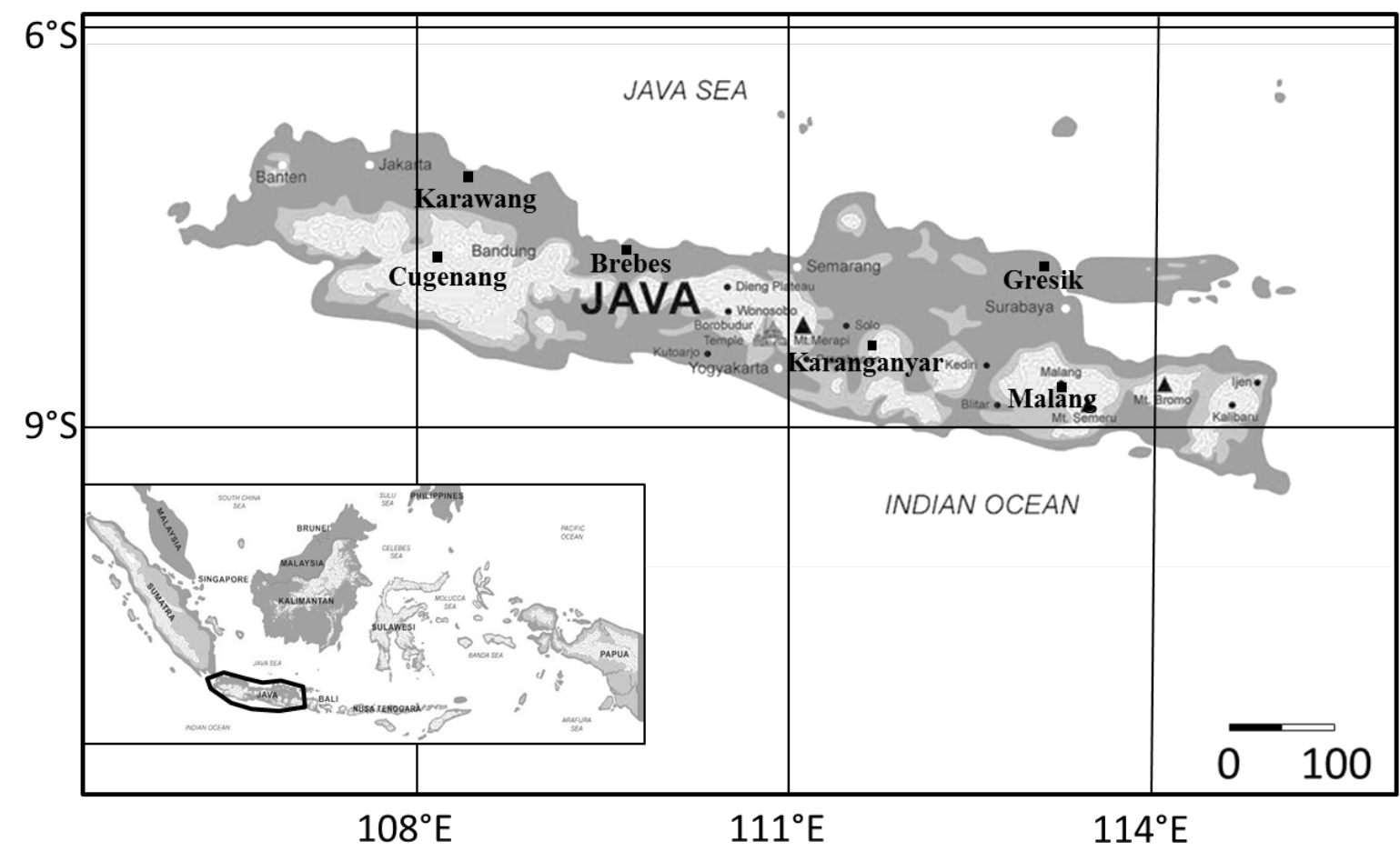

Figure 3 Java map

The study areas have varied environment condition and agriculture management (Table 1). Lowland area characterize is flat paddy field that divided by bund to control the water supply and height. In the upland area, most area is steep around 25\% slope and some portion of the valley bottom has plain and undulating slopes.

Tabel 1 Description of study areas

\begin{tabular}{|c|c|c|c|c|c|c|}
\hline Description & Cugenang & Karawang & Karanganyar & Brebes & Malang & Gresik \\
\hline Altitude (masl) & $527-856$ & $33-53$ & $403-714$ & $26-44$ & $526-684$ & $14-41$ \\
\hline Rainfall (mm/year) & 4553.8 & 1364.5 & 3755 & 2544.5 & 3104.5 & 2467 \\
\hline $\begin{array}{l}\text { Rice growing } \\
\text { system }\end{array}$ & Transplanted & Transplanted & Transplanted & Transplanted & Transplanted & $\begin{array}{l}\text { Direct } \\
\text { seeding }\end{array}$ \\
\hline Rice cultivation & 3 & $2-3$ & 2 & $1-2$ & 3 & 2 \\
\hline Rotation* & R-H/R-R & $\mathrm{R}-\mathrm{R}$ & R-H/R-R & $\mathrm{R}-\mathrm{O}-\mathrm{O} / \mathrm{R}$ & R-H/R-R & $\mathrm{R}-\mathrm{F} / \mathrm{H}-\mathrm{R}$ \\
\hline $\begin{array}{l}\text { Weed control } \\
\text { methods }\end{array}$ & $\begin{array}{l}\text { Manual } \\
\text { handweedin } \\
\text { g }\end{array}$ & $\begin{array}{l}\text { Manual } \\
\text { handweeding } \\
\text { and herbicide }\end{array}$ & $\begin{array}{l}\text { Manual } \\
\text { handweeding } \\
\text { and herbicide }\end{array}$ & $\begin{array}{l}\text { Manual } \\
\text { handweedin } \\
\text { g and } \\
\text { herbicide }\end{array}$ & $\begin{array}{l}\text { Manual } \\
\text { handweeding }\end{array}$ & $\begin{array}{l}\text { Manual } \\
\text { handweedi } \\
\text { ng and } \\
\text { herbicide }\end{array}$ \\
\hline Water management & $\begin{array}{l}\text { Technical } \\
\text { irrigation }\end{array}$ & $\begin{array}{l}\text { Technical } \\
\text { irrigation }\end{array}$ & $\begin{array}{l}\text { Technical } \\
\text { irrigation }\end{array}$ & $\begin{array}{l}\text { Technical } \\
\text { irrigation }\end{array}$ & $\begin{array}{l}\text { Technical } \\
\text { irrigation }\end{array}$ & $\begin{array}{l}\text { Semi } \\
\text { technical } \\
\text { irrigation }\end{array}$ \\
\hline $\begin{array}{l}\text { Harvested area } \\
\text { (ha)** }\end{array}$ & 159.229 & 187.892 & 48.783 & 91.877 & 65.171 & 53.109 \\
\hline
\end{tabular}

* Abbreviations: $\mathrm{R}=$ rice, $\mathrm{H}=$ horticulture crops, $\mathrm{O}=$ onion, $\mathrm{F}=$ fish

** Kementrian Dalam Negeri RI (2010) 


\section{References}

Bakrie, B. 1996. Feeding management of ruminant livestock in Indonesia. In: Ruminant Nutrition and Production in the Tropics and Subtropics. ACIAR Monograph No. 36. $151 \mathrm{p}$.

Bambaradeniya, C.N.B. and F.P. Amerasnghe. 2003. Biodiversity associated with the rice field agroecosystem in Asian countries: A brief review. Working Paper 63. International Water Management Institute. Colombo, Sri Lanka

Bappenas (National Development Planning Board) 2003. Luas panen, produktivitas dan produksi padi di Indonesia (GKG) (Harvested area, productivity and production of rice in Indonesia). Avalable at: http://www.bappenas.go.id/unit-kerja/deputi-bidang-sumberdaya-alam-dan-lingkungan-hidup/direktorat-pangan-dan-pertanian/luas-panenproduktivitas-dan-produksi-padi-indonesia-gkg/?\&kid=1390384257 (last accessed on 10 April 2013)

Barker, R., R.W. Herdt and B. Rose. 1985. The Rice Economy of Asia. Resources for the Future and The International Rice Research Institute. Washington DC

Boling, A., T.P. Tuong, B.A.M. Bouman, M.V.R. Murty and S.Y. Jatmiko. 2000. Effect of climate, agrohydrology, and management on rainfed rice production in Central Java, Indonesia: a modeling approach. In: Proceedings of the International Workshop on Characterizing and Understanding Rainfed Environments, 5-9 Dec. 1999, Bali, Indonesia. International Rice Research Institute. Los Baños

Chairul, S.M., Mulyadi, and Idawati. 2000. Translocations of 2,4D $-{ }^{14} \mathrm{C}$ herbicides in weed and rice plant on irrigated rice field system. Risalah Pertemuan Ilmiah Penelitian dan Pengembangan Teknologi Isotop dan Radiasi. 151-155

Chang, T. and E.A. Bardenas. 1965. The morphology and varietal characteristics of the rice plant. Technical Bulletin. 4. 5-7

Chauhan, B.S. and D.E. Johnson. 2009. Influence of tillage systems on weed seedling emergence pattern in rainfed rice. Soil and Tillage Research. 106. 15-21

Fairhurst, T.H and A. Dobermann. 2002. Rice in the global food supply. Rice Production. Better Crops International. Special Supplement. Volume 16. p: 3-6

Fukai, S. J. Basnayake and M. Cooper. 2000. Modeling water availability, crop growth, and yield of rainfed lowland rice genotypes in northeast Thailand. In: Proceedings of the International Workshop on Characterizing and Understanding Rainfed Environments, 59 Dec. 1999, Bali, Indonesia. International Rice Research Institute. Los Baños 
Harnpichitvitaya D., G. Trébuil, T. Oberthür, G. Pantuwan, I. Craig, T.P. Tuong, L.J. Wade, and D. Suriya-Arunroj. 2000. Identifying soil suitability for subsoil compaction to improve water and nutrient-use efficiency in rainfed lowland rice. In: Proceedings of the International Workshop on Characterizing and Understanding Rainfed Environments, 5-9 Dec. 1999, Bali, Indonesia. International Rice Research Institute. Los Baños

Inamura, T., S. Miyagawa, O. Singvilay, N. Sipaseauth and Y. Kono. 2003. Competition between weeds and wet season transplanted paddy rice for nitrogen use, growth and yield in the central and northern regions of Laos. Weed Biology and Management. 3. 213-221

Itoh, K., G.X. Wang and S. Ohba. 1999. Sulfonylurea resistance in Lindernia micrantha, an annual paddy weed in Japan. Weed Research. Volume39. p: 413-423

Kadir, M. 2007. Effectiveness of several dosage and time of application of 2,4 Dimetylamina herbicide to controlling Echinochloa colonum, Echinochloa crus-galli, and Cyperus Iria weed in paddy. Jurnal Agrisistem. 3. 1. 43-49

Kartohardjono, A. 2011. Penggunaan musuh alami sebagai komponen pengendalian hama padi berbasis ekologi [Usage of Natural Enemies as a Component of Rice Insect Control on Ecological Bases]. Pengembangan Inovasi Pertanian 4. 29-46

Kastanja, A.Y. 2011. Identifikasi jenis dan dominansi gulma pada pertanaman padi gogo (Studi kasus di Kecamatan Tobelo Barat, Kabupaten Halmahera Utara) [Identifying weed species and dominancy in gogo rice cultivation]. Jurnal Agroforestri. 6. 40-46

Kudsk, P. And J.C. Streibig. 2003. Herbicides - a two-edge sword. Weed Research. Volume 43. p: $90-102$

Li, R.H. and Qiang S. 2009. Composition of floating weed seeds in lowland rice fields in China and the effects of irrigation frequency and previous crops. Weed Research 49. 417-427

Lu, J., T. Ookawa and T. Hirasawa. 2000. The effects of irrigation regimes on the water use, dry matter production and physiological responses of paddy rice. Plant and Soil. 223. 207-216

Major, J., C. Steiner, A. Ditommaso, N.P.S. Falcão and J. Lehmann. 2005. Weed composition and cover after three years of soil fertility management in the central Brazilian Amazon: Compost, fertilizer, manure and charcoal applications. Weed Biology and Management. 5. 69-76 
Marpaung, I.S., Y. Parto and E. Sodikin. 2013. Evaluation of density planting and weed control methods in direct seeded rice in the tidal wetland. Jurnal Lahan Suboptimal. 2. 1. 93-99

Maruyama, T. and K.K. Tanji. 1997. Physical and Chemical Processes of Soil Related to Paddy Drainage. Shinzansha Sci. \& Tech. Tokyo

McDonald, A.J., S.J. Riha and A. Ditommaso. 2009. Early season height differences as robust predictors of weed growth potential in maize: new avenues for adaptive management? Weed Research. Volume: 50. p: 110-119

Nurjannah, U. 2003. Effects of glyphosate and 2,4-D dosages on weed succession and no tillage soybean. Jurnal Ilmu-ilmu Pertanian Indonesia. 5 (1). 27-33

Nyarko, K.A. and Datta S.K.D. 1993. Effects of light and nitrogen and their interaction on the dynamics of rice-weed competition. Weed Research. 33. 1-8

Pane, H. and S.Y. Jatmiko. 2009. Pengendalian gulma pada tanaman padi [Weed control on rice plant]. Available at: http://www.litbang.deptan.go.id/special/padi/bbpadi_2009_itp_10.pdf (last accessed on 28 March 2014)

Pane, H., E.S. Noor, Z. Susanti and M. Mortimer. 2002. Weed characterization in Walik Jerami rice in rainfed lowland area. Penelitian Pertanian Tanaman Pangan. 21. 3: 6-14

Pane, H., E.S. Noor, M. Dizon and A.M. Mortimer. 2000. Weed communities of gogorancah rice and reflections on management. In: Proceedings of the International Workshop on Characterizing and Understanding Rainfed Environments, 5-9 Dec. 1999, Bali, Indonesia. International Rice Research Institute. Los Baños

Shibayama, H. 2001. Weeds and weed management in rice production in Japan. Weed Biology and Management. 1. 53-60

Singh, Y., V.P. Singh, G. Singh, D.S. Yadav, R.K.P. Sinha, D.E. Johnson, and A.M. Mortimer. 2011. The implications of land preparation, crop establishment method and weed management on rice yield variation in the rice-wheat system in the Indo-Gangetic plains. Field Crops Research. 121. 64-74

Soerjani, M., A.J.G.H. Kostermans and G. Tjitrosoepomo. 1987. Weeds of rice in Indonesia. Balai Pustaka. Jakarta

Soekisman, T. 2010. Integrated management of paddy and aquatic weeds in Indonesia. Available at: http://www.agnet.org/htmlarea_file/library/20110721174434/eb367b.pdf (last accessed on 06 March 2014) 
Tomita, S., S. Miyagawa, Y. Kono, C. Noichana, T. Inamura, Y. Nagata, A. Sributta and E. Nawata. 2003. Rice yield losses by competition with weeds in rainfed paddy fields in north-east Thailand. Weed Biology and Management. Volume 3. p: 162-171.

Tuong, T.P., S.P. Kam, L. Wade, S. Pandey, B.A.M. Bouman, B. Hardy. 2000. Characterizing and understanding rainfed environments. Proceedings of the International Workshop on Characterizing and Understanding Rainfed Environments, 5-9 Dec. 1999, Bali, Indonesia. International Rice Research Institute. Los Baños 


\section{Weed communities of Javanese paddy fields in response to altitude and agronomic practices}

N R KUMALASARI \& E BERGMEIER

re-submitted in Weed Research

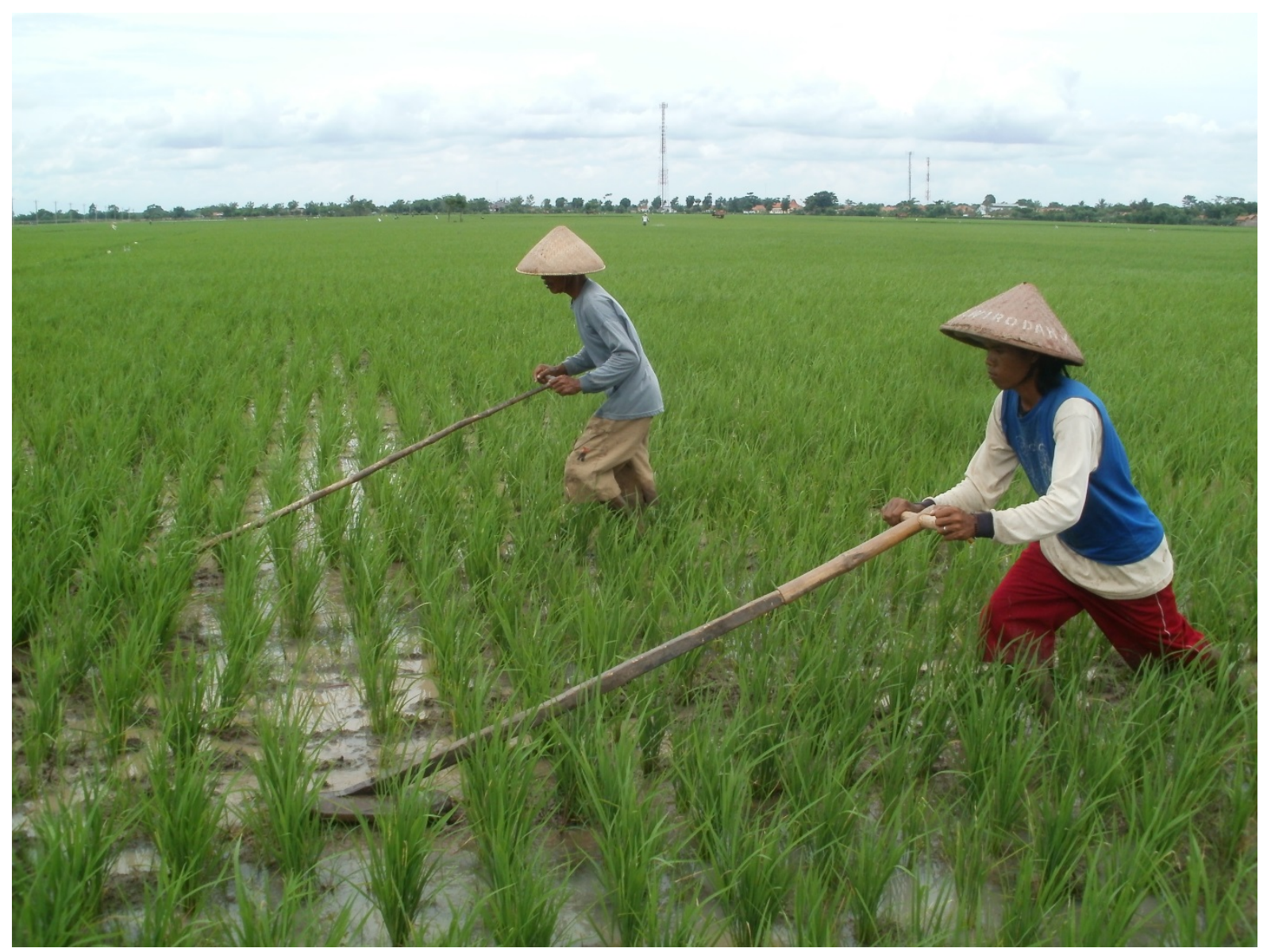




\begin{abstract}
We examined the diversity and composition of weed communities in paddy fields and their relation to environmental factors, agricultural practice and cropping period. The research was conducted in three lowland (below $100 \mathrm{~m}$ a.s.l.) and three mid-elevation areas (above $400 \mathrm{~m}$ a.s.l.) in Java, Indonesia, during two cropping periods (rain and dry season). In the examined 198 paddy field plots we recorded 171 plant species of which Poaceae, followed by Asteraceae, were most common. In the mid-elevation fields we found a higher mean number of species per plot than in the lowlands. Weed cover and diversity were higher in post-harvest fallow than in cropped plots. Six plant communities were classified by means of multivariate analysis, with species combinations related to altitude, herbicide application, water level and cropping period. Elevation and water level gradients were the most important factors controlling species composition in paddy fields. Herbicide application affected chiefly the vegetation of lowland fields. Weed management corresponded to the field water level since farmers flooded their fields to control weed growth.
\end{abstract}

Keywords: cropping period, elevation gradient, fallow, herbicide treatment, plant communities, paddy fields, rice weeds, vegetation classification 


\section{Introduction}

The island of Java with about 5.4 million hectares of paddy fields is the most important region for rice cultivation in Indonesia (Indonesian National Development Planning Board, 2003). Rice is cultivated from the lowlands to mid-altitudes, on irrigated as well as rainfed fields (Boling et al., 2008). Depending on the area, irrigation system and water resources, Javanese farmers cultivate rice plants in one or up to three periods per year. Sumarno (2008) divided a year in three cropping periods: the first is defined by rice cultivation starting in the wet season (end of October till March); the second season is semi-dry (April till July), and the third is a dry season (August-October). If water is insufficient for rice cultivation in the dry season, farmers typically cultivate short duration food crops, such as corn, soybean and horticultural plants.

Rice in Java is mostly cultivated under wet conditions in lowland and mid-elevation areas. Farmers control water by earthen walls (bunds) around the fields. In mountainous areas, terraced paddy field systems with traditional irrigation management occur (Sukristiyonubowo, 2011). The varied conditions in different areas and different altitudes suggest differences in cropping period, land preparation, weed control and agricultural techniques. The first step of land preparation is puddling by adding water to the paddy field until the water reaches a level of $1-5 \mathrm{~cm}$ above the soil surface, thereafter ploughing and harrowing. Puddling facilitates weed control (Shrestha et al, 2002) and transplanting of rice seedlings. In dry fields, the land is prepared by ploughing and frequently by applying herbicides.

Weeds on paddy fields are important components in the agriculture of Java and may add considerably to the diet of domestic livestock (Kumalasari et al. 2013). Dominant weeds may affect the rice biomass depending on the water and field management, i.e. land puddling, leveling and preparation (Tomita et al., 2003a; Johnson et al., 2004), while less competitive weeds were found to have no effect on the rice crop (Inamura et al., 2003). Vigorous rice growth may in turn affect weed biomass and species composition (Rodenburg et al., 2009; Maulida \& Arisoesilaningsih, 2011) In Java, farmers influence weed growth on paddy fields indirectly by land preparation, water management, fertilizing and crop management, and directly by manual or mechanic weeding and by herbicide usage (Pane and Jatmiko, 2009).

Local farmers typically identify and vernacularly name chiefly the dominant weeds. A catalogue of 266 species of rice weeds in Indonesia was provided by Soerjani et al. (1987). Yakup (2007) found 70 weed species in cultivated fields of West Java. Soekisman (2010) 
classified the most common weeds of paddy fields into three functional groups, i.e. broadleaved weeds, cyperaceous weeds and grassy (poaceous) weeds.

In this study, we examined the diversity and composition of major weed communities and their relation to environmental factors in paddy fields in Java, attempting to contribute to a better understanding of the ecology and distribution of rice weed vegetation. . The following research questions are addressed: (1) Which plant communities can be observed in the paddy fields of Java and what is their distribution? (2) Which environmental and management factors influence the variation in plant species composition and richness in the paddy fields?

\section{Materials and Methods}

\section{Study area and data acquisition}

We used data from original research conducted in paddy fields in three lowland and three mid-elevation areas in Java, Indonesia (Table 1; Fig. 1). The island of Java is situated in the humid tropics with distinct Monsoon-type rainfall and dry seasons (D’Arrigo \& Smerdon, 2008; Tukidin, 2010).

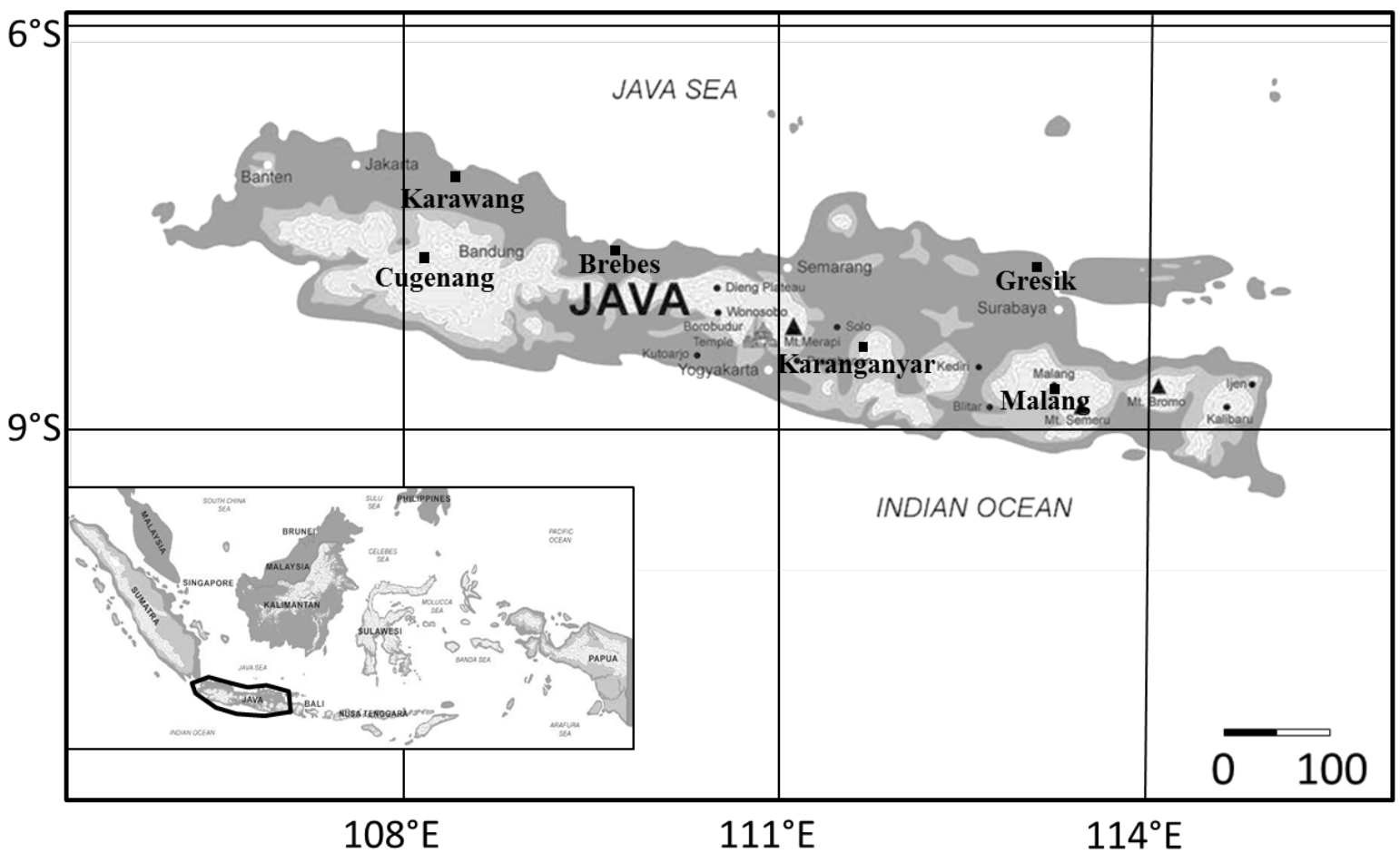

Figure 1 The island of Java and the study areas (BPN, 2013) 
Table 1 Geographic and climatic data regarding the six study areas in the three provinces of West, Central and East Java

\begin{tabular}{|c|c|c|c|c|c|}
\hline Area & Province & $\begin{array}{l}\text { Coordinates } \\
\text { (range) }\end{array}$ & $\begin{array}{l}\text { Elevation } \\
\text { range (m } \\
\text { a.s.l.) }\end{array}$ & $\begin{array}{l}\text { Mean annual } \\
\text { precipitation* } \\
(\mathrm{mm})\end{array}$ & $\begin{array}{l}\text { Mean } \\
\text { annual } \\
\text { temperature } \\
*\left({ }^{\circ} \mathrm{C}\right) \\
\end{array}$ \\
\hline Cugenang & West Java & $\begin{array}{l}\text { S } 06^{\circ} 47-50^{\prime} \\
\text { E } 107^{\circ} 03-06^{\prime}\end{array}$ & $565-856$ & 4554 & 20.9 \\
\hline Karawang & West Java & $\begin{array}{l}\text { S } 06^{\circ} 20-23^{\prime} \mathrm{E} \\
107^{\circ} 29-32^{\prime}\end{array}$ & $33-53$ & 1364 & 27.5 \\
\hline Karanganyar & Central Java & $\begin{array}{l}\text { S } 06^{\circ} 58^{\prime}-07^{\circ} 01^{\prime} \\
\text { E } 108^{\circ} 58^{\prime}-109^{\circ} 01^{\prime}\end{array}$ & $403-714$ & 3755 & 27.5 \\
\hline Brebes & Central Java & $\begin{array}{l}\text { S 0734-37' } \\
\text { E } 111^{\circ} 01-04^{\prime}\end{array}$ & $31-44$ & 2544 & 28.1 \\
\hline Malang & East Java & $\begin{array}{l}\text { S 07053-56' } \\
\text { E } 112^{\circ} 34-37^{\prime}\end{array}$ & $684-526$ & 3104 & 23.9 \\
\hline Gresik & East Java & $\begin{array}{l}\text { S } 07^{\circ} 13-15^{\prime} \\
\text { E } 112^{\circ} 29-31^{\prime}\end{array}$ & $14-30$ & 2467 & 28.6 \\
\hline
\end{tabular}

*Courtesy of BMKG Bogor, Semarang and Malang, 2011

The data were collected in October-January 2011/12 and May-July 2012. In each of the six areas landscape sections of ca. 5 x $5 \mathrm{~km}$ were selected and stratified. In each section 33 random plots were sampled in paddy fields, with 15 plots in the first and 18 in the second survey period. One field contained not more than one plot. Plot size was $20 \mathrm{~m}^{2}$ each. In all, 99 plots were in the three lowland areas (below $100 \mathrm{~m}$ a.s.l.), and another 99 in the three midelevation areas (above $400 \mathrm{~m}$ a.s.l.). The vascular plant species composition and abundance was surveyed in 151 plots in cropped fields (C) and 47 in intermittently fallow fields (F), the latter representing 5-12 plots per landscape section. The seven-grade Braun-Blanquet scale (r, $+, 1,2,3,4,5)$ was used to record plant cover-abundance (e.g., van der Maarel 2005). The plots were further classified by rice plant establishment, i.e. transplanted (TF) vs. directly seeded (DSF), and by weed management, i.e. manual weeding (M) and/or herbicide application (H). We asked the farmers about irrigation methods and water sources and noted current water level and soil properties. The water conditions in paddy fields were recorded as unflooded with dry soil (-1), with moist soil but not saturated (0), and with saturated soil but no standing water $(0.1-0.5)$; flooded soils were scored equivalent to the depth (in $\mathrm{cm}$ ) of the standing water (1-7).

We identified plant species in paddy fields using Soerjani et al. (1987). Plants not identified in the field were collected and identified in the laboratory using Harada et al. (1987), Moody et al. (1984), and Backer (1973). Plant names were updated using The Plant List (2010). 
Soil samples of $200 \mathrm{~g}$ each were collected as a composite of the surface soil (0-10 cm depth) from five spots in each plot. All soil samples were analyzed in the Laboratory of Soil Sciences and Land Resources IPB, measuring $\mathrm{pH}\left(\mathrm{H}_{2} \mathrm{O}\right)$, organic $\mathrm{C}$, total nitrogen $(\mathrm{N})$, phosphorus (P), potassium $(\mathrm{K})$ and soil fractions. The soil $\mathrm{pH}$ was measured in the supernatant suspension of a 1:2.5 soil:liquid mixture $\left(\mathrm{pH}-\mathrm{H}_{2} \mathrm{O}\right)$. Organic carbon was measured by the Walkley-Black procedure. Nitrogen analysis followed the Micro-Kjeldahl method and resulted in amounts of $\left(\mathrm{NH}_{4}\right)_{2} \mathrm{SO}_{4}$, and then \%N was calculated. Available $\mathrm{P}$ was measured by the Bray and Kurtz no I method, and potassium (K) by the sulfuric acid extraction method. According to the soil particle analysis the sand was fractioned by dry sieving, while the clay and silt fraction were determined by the pipette method.

\section{Data analysis}

To classify the plot data and identify the plant communities we performed a Braun-Blanquet table sorting analysis using TWINSPAN (with pseudospecies cut levels $0,2,5,10,20$ ) under JUICE 7.0 (Tichý 2002). TWINSPAN is a well-established tool for hierarchical classification of vegetion plot data with divisive clustering being applied to the result of correspondence analysis (Wildi 2010). A structured synoptic table was constructed showing species constancy values of six TWINSPAN-generated clusters or plant communities interpretable through differential species, i.e. species exclusive to a plant community, or almost so, and occurring with at least $25 \%$ constancy.

We used Non-metric Multidimensional Scaling (NMDS) to examine the plant community structure in relation to management factors and environmental conditions, i.e. altitude, season, water level, soil properties ( $\mathrm{P}, \mathrm{K}, \mathrm{N}$ total, C-organic and $\mathrm{pH}$ ) using the WinKyst add-on of the CANOCO 4.5 package. NMDS is an iterative ordination optimized for two dimensions (McCune \& Grace 2002; Wildi 2010). NMDS biplot diagrams display plot or species scores according to floristic similarities of the surveyed plots. The length of a vector indicates the strength of the correlation between that environmental factor and the main floristic gradient. For the calculations we used the transformed mean percentage values of the Braun-Blanquet cover-abundance scale $(r=1 \%,+=2 \%, 1=3 \%, 2=15 \%, 3=38 \%, 4=63 \%$, $5=88 \%$ ), and Bray-Curtis as distance measure. Based on the inspection of the stress plot, the number of dimensions for NMDS was set to two. Thus, the final NMDS was computed using two axes. 


\section{Results}

\section{Species richness}

In all 198 paddy field plots we recorded 171 plant species belonging to 40 families of which Poaceae (23.2\%), Asteraceae (14.0\%), Rubiaceae (4.8\%) and Fabaceae (4.3\%) were most common. We found 134 plant species in the mid-elevation fields and 109 species in the lowlands. The most common species were Echinochloa crus-galli (115 plots), Alternanthera philoxeroides (87), Ludwigia hyssopifolia (71) and Fimbristylis littoralis (61). Mean plant species richness per plot was lowest in Karawang (6.0, western lowland) and highest in Malang (12.9, eastern mid-elevation). In the western, central and eastern areas species richness per plot increased with altitude by 21-39\%.

We found 72 weed species occurring only in the first (wet) survey period and 11 species only in the second (dry) period. Species richness was also highest in the wet period. The most common weed species encountered in the plots during the first period were Echinochloa colona, E. crus-galli and Ageratum conyzoides, while Leptochloa chinensis and Azolla pinnata were observed in most examined plots in the drier second period.

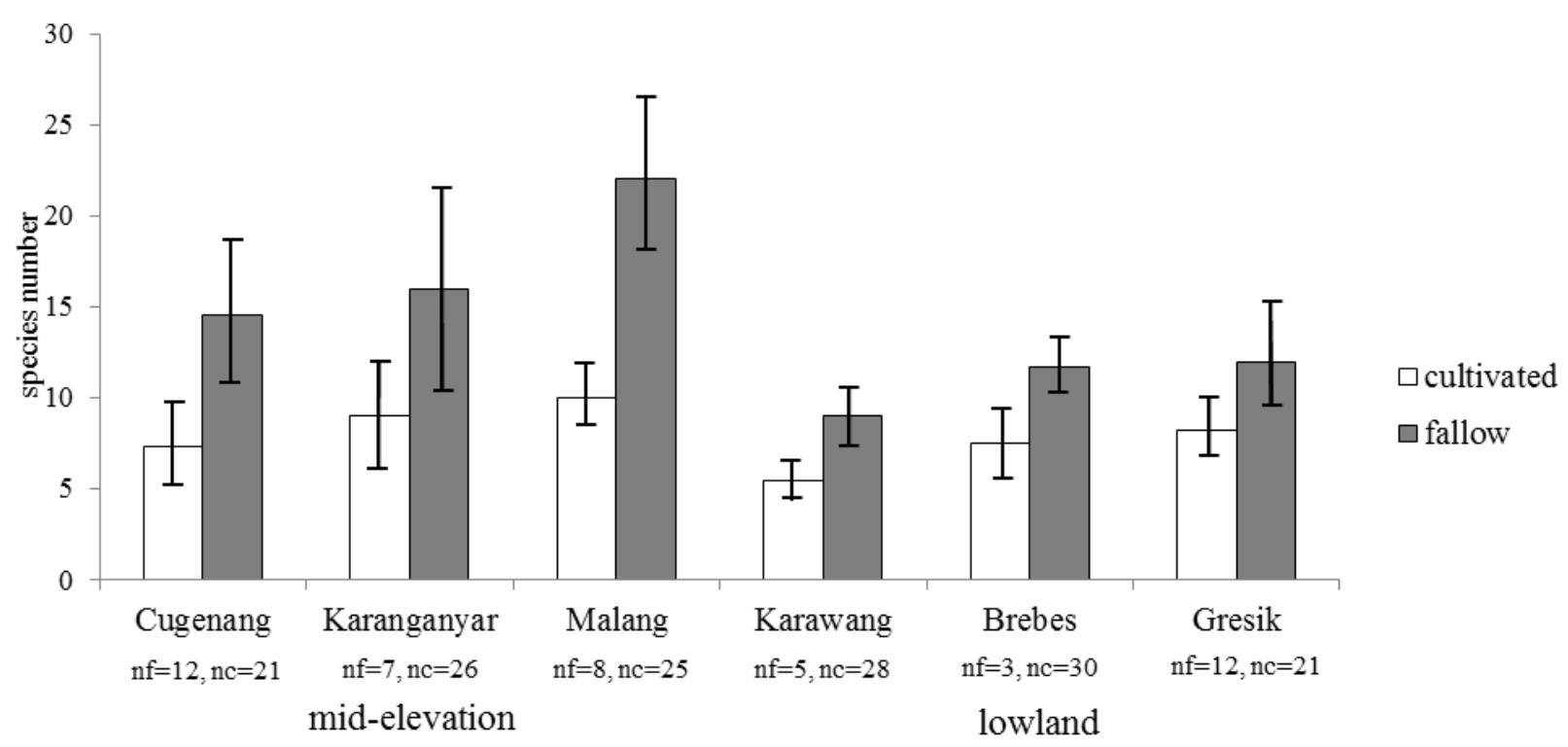

Figure 2 Mean plant species numbers per plot and standard deviation in mid-elevation (Cugenang, Karanganyar, Malang) and lowland (Karawang, Brebes, Gresik) cropped and post-harvest fallow paddy fields; $\mathrm{nf}=$ number of fallow plots; $\mathrm{nc}=$ number of cropped plots 
Table 2 The most common plant species in cropped and intermittently fallow paddy fields in Java

\begin{tabular}{llrr}
\hline Weed species & Abbrev. in Fig. 4b & Cropped (\%)* & Fallow (\%)** \\
\hline Alternanthera philoxeroides (Mart.) Griseb. & Alt.phil & 43.0 & 44.7 \\
Ludwigia adscendens (L.) H. Hara & Lud.adsc & 19.2 & 17.0 \\
Leptochloa chinensis (L.) Nees & Lep.chin & 26.5 & 29.8 \\
Echinochloa crus-galli (L.) P.Beauv. & Ech.crus & 65.6 & 31.9 \\
Ludwigia hyssopifolia (G.Don) Exell & Lud.hyss & 37.1 & 29.8 \\
Monochoria vaginalis (Burm.f.) C.Presl & Mon.vagi & 28.4 & 17.0 \\
Pistia stratiotes L. & Pis.stra & 26.5 & 17.0 \\
Fimbristylis littoralis Gaudich. & Fim.litt & 25.8 & 44.7 \\
Ludwigia octovalvis (Jacq.) P.H.Raven & Lud.octo & 15.2 & 38.3 \\
Alternanthera sessilis (L.) R.Br. ex DC. & Alt.sess & 23.2 & 36.2 \\
Echinochloa colona (L.) Link & Ech.colo & 15.2 & 36.2 \\
Eclipta prostrata (L.) L. & Ecl.pros & 12.6 & 31.9 \\
Ageratum conyzoides (L.) L. & Age.cony & 4.7 & 31.9 \\
Cynodon dactylon (L.) Pers. & Cyn.dact & 17.2 & 29.8 \\
Lindernia ciliata (Colsm.) Pennell & Lin.cili & 12.6 & 29.8 \\
Commelina nudiflora L. & Com.nudi & 20.6 & 27.7 \\
Limnocharis flava (L.) Buchenau & Lym.flav & 14.6 & 25.5 \\
Panicum repens L. & Pan.repe & 8.6 & 25.5 \\
Centipeda minima (L.) A. Br. \& Asch. & Cen.mini & 0.7 & 23.4 \\
Cyperus iria L. & Cyp.iria & 11.9 & 21.3 \\
Phyllanthus sp. & Phy.sp & 5.5 & 21.3 \\
Basilicum polystachyon (L.) Moench & Bas.poly & 3.3 & 21.3 \\
Oldenlandia diffusa (Willd.) Roxb. & Old.diff & 1.9 & 19.1 \\
\hline * N & field &
\end{tabular}

* Number of plots with species $i$ in cultivated fields/total number of cultivated plots) x 100\%

** Number of plots with species $i$ in fallow fields/total number of fallow plots) x 100\%

In all areas the number of plant species per plot was considerably higher in intermittently fallow fields than in cropped fields (Fig. 2). A. philoxeroides, L. chinensis and Commelina nudiflora were common and widespread in both types of fields (Table 2), while E. crus-galli, L. hyssopifolia and Monochoria vaginalis occurred with cover values of more than $5 \%$ chiefly in cropped fields. Lowland and some mid-elevation fields were intermittently fallow during the dry season. In most mid-elevation fields, water was available throughout the year and they were re-flooded after harvesting. Dry fallow fields were dominated by graminoids ( $F$. littoralis, E. colona, Cynodon dactylon), and broadleaved weeds such as Ludwigia octovalvis, A. conyzoides and Eclipta prostrata were also common. Pistia stratiotes and M. vaginalis were widespread and abundant on wet fallow fields. Myriophyllum aquaticum and Dopatrium junceum, while also widespread in wet fallows, contributed little to total vegetation cover. 
In mid-elevation fields with sufficient water resources post-harvest flooding controls weed growth. Most mid-elevation paddy fields were thus not treated with herbicides while in the lowlands most fields were treated (Fig. 3). As a result, plant communities of lowland fields were much more affected by herbicide application than mid-elevation vegetation. Some plant species were found only in paddy fields without herbicide application, such as Andrographis sp., Alternanthera pungens, Sonchus arvensis, Spilanthes sp., Brassica sp, Hippobroma longiflora, Drymaria sp. and various Fimbristylis species. Different herbicide active ingredients were used in the west (Metsulforon-methyl) and in the east (Paraquat dichloride). In West Java, we found Sagittaria guayanensis, Phyla nodiflora, Basilicum polystachyon, Passiflora foetida and Oryza rufipogon only in paddy fields without herbicide application, while in East Java these species were found in many plots whether or not herbicides were applied. Although not significant due to the small number of non-treated lowland fields we found that herbicide application in the lowland areas reduces the number of weed species by $20 \%$ to less than half of the number of species on non-treated fields (Fig. 3). In mid-elevation areas, herbicide application was rare and no significant effect on the number of weed species was found.

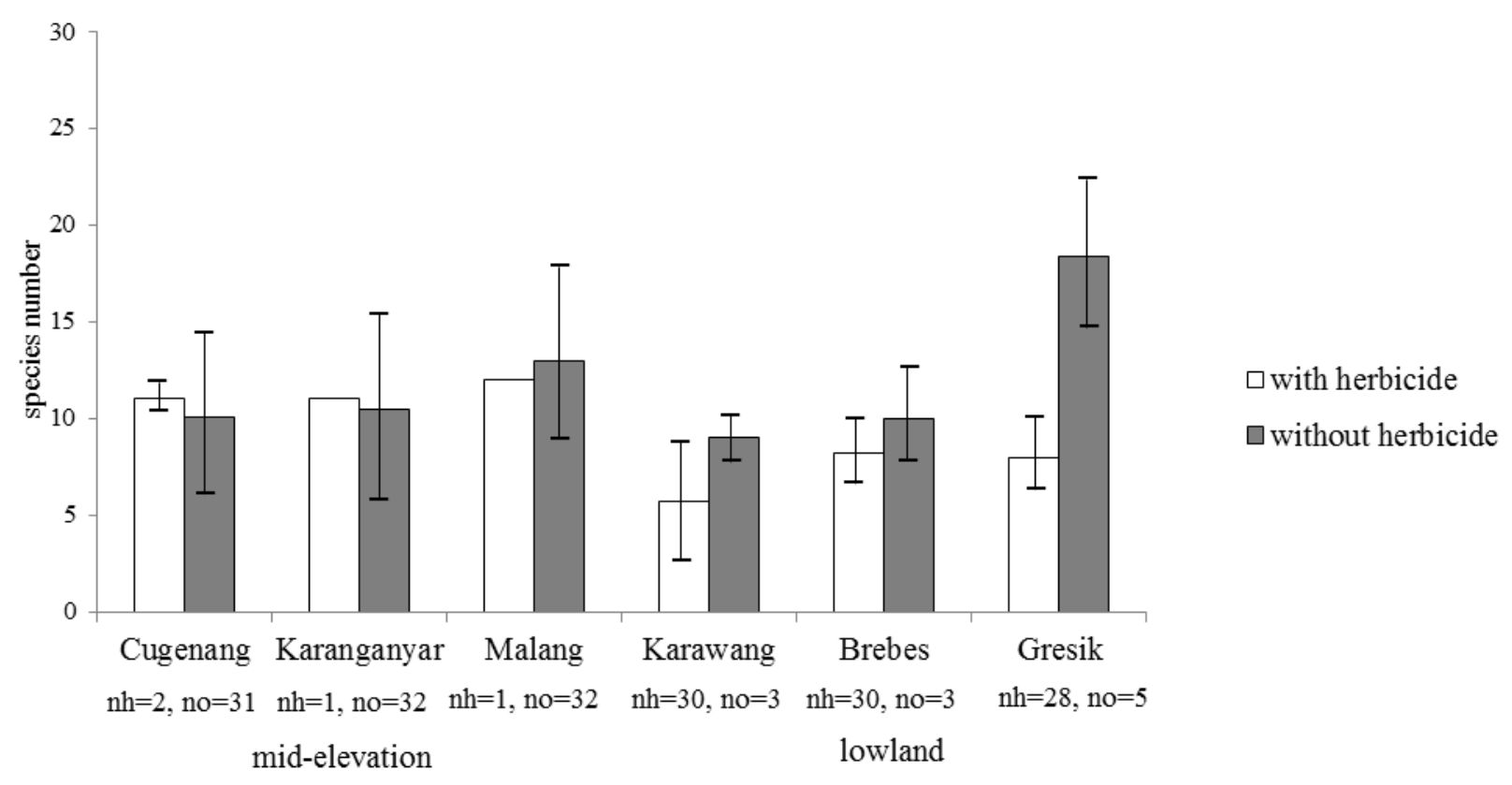

Figure 3 Mean plant species numbers in mid-elevation (Cugenang, Karanganyar, Malang) and lowland (Karawang, Brebes, Gresik) paddy fields with herbicide and without herbicide treatment; $\mathrm{nh}=$ number of plots with herbicide; no = number of plots without herbicide 
Plant communities and environment relations

The synoptic table shows groups of differential taxa found diagnostic for six different clusters or plant communities (Table 3).

The first TWINSPAN-generated division separated two groups of clusters related to water availability. Clusters I and II, representing relatively dry conditions, were further divided corresponding to their cropping status, i.e. intermittently fallow or cropped. Diagnostic species of cluster I (dry fallows) included L. chinensis, E. colona, S. indica, A. baccifera, and E. prostrata. Cluster II that represented dry cropped plots had many diagnostic species including Eriocaulon sp., D. setigera, C. dactylon, T. trilobatum and C. rotundus.

Clusters III-VI represented wet conditions with different water depth and rice plant age. Cluster III is differentiated by hydrophytes such as P. stratiotes, A. pinnata and L. flava indicating flooded cropped fields around 10-30 days after transplanting. In the latter three groups, plots represented wet or moist paddy field more than 30 days after transplanting. In the fourth group, perennial herbs such as Marsilea crenulata, Commelina diffusa and $H$. longiflora were common. The fifth group was rather poorly characterized by E.crus-galli and C. sieberianus, whereas the last group was well differentiated by L. octovalvis, A. conyzoides, and Oldenlandia diffusa.

Table 3 Synoptic table of rice weed communities (plant species constancy, \%). Differential species of $10-<20 \%$ constancy are highlighted light grey; highly diagnostic species (20\% or more) are highlighted dark gray.

\begin{tabular}{|c|c|c|c|c|c|c|c|}
\hline & $\begin{array}{c}\text { Abbrev. in } \\
\text { Fig. 4b }\end{array}$ & $\begin{array}{c}\mathrm{I} \\
(25) \\
\end{array}$ & $\begin{array}{c}\text { II } \\
(22) \\
\end{array}$ & $\begin{array}{c}\text { III } \\
(56)\end{array}$ & $\begin{array}{l}\text { IV } \\
(22) \\
\end{array}$ & $\begin{array}{c}\mathrm{V} \\
(39) \\
\end{array}$ & $\begin{array}{c}\mathrm{VI} \\
(34) \\
\end{array}$ \\
\hline \multicolumn{8}{|l|}{ Diagnostic species for Cluster 1} \\
\hline Leptochloa chinensis (L.) Nees & Lep.chin & 80 & 14 & 16 & 9 & 41 & 12 \\
\hline Echinochloa colona (L.) Link & Ech.colo & 60 & 9 & 13 & 18 & 13 & 21 \\
\hline Sphaeranthus indicus L. & Spa.indi & 24 & - & - & - & 10 & - \\
\hline Euphorbia prostrata Aiton & Eup.pros & 20 & 5 & - & - & 3 & 6 \\
\hline Ammannia baccifera $\mathrm{L}$. & Amm.bacc & 16 & - & - & - & - & 3 \\
\hline Persicaria barbata (L.) H. Hara & Per.barb & 12 & - & 4 & - & - & - \\
\hline \multicolumn{8}{|l|}{ Diagnostic species for Cluster 2} \\
\hline Eriocaulon sp. & Eri.ocsp & - & 45 & - & - & 3 & 3 \\
\hline Digitaria setigera Roth & Dig.seti & 8 & 45 & 2 & - & - & 3 \\
\hline Cynodon dactylon (L.) Pers. & Cyn.dact & 16 & 68 & 18 & - & - & 32 \\
\hline Typhonium trilobatum (L.) Schott & Typ.tril & - & 27 & - & - & - & - \\
\hline Cyperus rotundus L. & Cyp.rotu & 12 & 59 & 4 & 5 & 3 & 29 \\
\hline Euphorbia hypericifolia L. & Eup.hype & 12 & 36 & - & - & - & 3 \\
\hline Amaranthus viridis L. & Ama.viri & - & 32 & - & 9 & - & - \\
\hline Phyllanthus niruri L. & Phy.niru & 24 & 45 & - & 5 & - & 3 \\
\hline Leersia hexandra Sw. & Lee.hexa & 24 & 41 & - & - & - & - \\
\hline Euphorbia heterophylla L. & Eup.hete & 8 & 36 & - & - & - & - \\
\hline Chloris barbata Sw & Chl.barb & 12 & 27 & - & - & - & - \\
\hline
\end{tabular}




\begin{tabular}{|c|c|c|c|c|c|c|c|}
\hline Pueraria phaseoloides var. javanica (Benth.) Baker & Pue.phas & - & 27 & - & 18 & - & - \\
\hline Heliotropium indicum L. & Hel.indi & 8 & 23 & - & 5 & - & 3 \\
\hline Ipomoea aquatica Forssk. & Ipo.aqua & - & 23 & - & - & - & - \\
\hline Axonopus compressus (Sw.) P.Beauv & Axo.comp & 8 & 18 & - & - & - & - \\
\hline Centrosema pubescens Benth. & Cen.pube & - & 18 & - & - & - & - \\
\hline \multicolumn{8}{|l|}{ Diagnostic species for Cluster 3} \\
\hline Pistia stratiotes L. & Pis.stra & - & - & 70 & - & - & 13 \\
\hline Azolla pinnata R.Br. & Azo.pinn & - & - & 38 & - & - & 9 \\
\hline Limnocharis flava (L.) Buchenau & Lim.flav & 6 & - & 38 & - & - & 26 \\
\hline Marsilea minuta L. & Mar.minu & 4 & - & 34 & - & 23 & 21 \\
\hline \multicolumn{8}{|l|}{ Diagnostic species for Cluster 4} \\
\hline Marsilea crenulata Desv. & Mar.cren & - & - & - & 91 & - & - \\
\hline Commelina diffusa Burm.f. & Com.diff & - & - & - & 45 & - & - \\
\hline Hippobroma longiflora (L.) G.Don & Eri.long & - & - & - & 41 & - & - \\
\hline Panicum repens $\mathrm{L}$. & Pan.repe & 6 & - & - & 41 & - & 3 \\
\hline Salvinia adnata Desv. & Sal.mole & - & 5 & 32 & 41 & 3 & 12 \\
\hline Monochoria vaginalis (Burm.f.) C.Presl & Mon.vagi & - & - & 14 & 50 & - & 3 \\
\hline Fimbristylis aestivalis Vahl & Fim.aest & - & - & - & 18 & - & - \\
\hline Alternanthera pungens Kunth & Alt.pung & - & - & - & 18 & - & 14 \\
\hline \multicolumn{8}{|l|}{ Diagnostic species for Cluster 5} \\
\hline Echinochloa crus-galli (L.) P.Beauv & Ech.crus & 24 & 86 & 54 & 68 & 90 & 29 \\
\hline Cyperus sieberianus Spreng. & Cyp.sibe & - & - & 4 & - & 13 & - \\
\hline \multicolumn{8}{|l|}{ Diagnostic species for Cluster 6} \\
\hline Ludwigia octovalvis (Jacq.) P.H.Raven & Lud.octo & 12 & - & 20 & - & 28 & 50 \\
\hline Ageratum conyzoides (L.) L. & Age.cony & 16 & - & 2 & 9 & 8 & 35 \\
\hline Oldenlandia diffusa (Willd.) Roxb. & Old.diff & 8 & 5 & - & 5 & - & 24 \\
\hline Brassica spp. & Bra.ssis & 12 & - & 2 & 9 & 8 & 26 \\
\hline Centipeda minima (L.) A. Br. \& Asch. & Cen.mini & 8 & - & 4 & 5 & - & 21 \\
\hline Cyperus iria L. & Cyp.iria & 28 & - & 5 & 5 & 13 & 35 \\
\hline Lindernia ciliata (Colsm.) Pennell & Lin.cili & 9 & - & 4 & 9 & 26 & 38 \\
\hline Cyperus difformis L. & Cyp.diff & 3 & - & - & - & 5 & 21 \\
\hline Paspalum conjugatum P.J.Bergius & Pas.conj & - & - & 5 & - & - & 15 \\
\hline \multicolumn{8}{|c|}{ Non differential species that reach at least $35 \%$ constancy } \\
\hline Alternanthera sessilis (L.) R.Br. ex DC. & Alt.sess & 36 & 18 & 14 & 18 & 28 & 50 \\
\hline Alternanthera philoxeroides (Mart.) Griseb. & Alt.phil & 24 & 27 & 36 & 64 & 46 & 68 \\
\hline Fimbristylis littoralis Gaudich. & Fim.litt & 56 & 14 & 16 & 18 & 33 & 53 \\
\hline Ludwigia hyssopifolia (G.Don) Exell & Lud.hyss & 8 & 14 & 32 & 50 & 51 & 50 \\
\hline
\end{tabular}

The methods of paddy management varied among the different areas, altitudes and even villages. Environmental and cultivation features of each cluster are summarized in Table 4. Cluster I comprises mostly lowland fields of the dry period (May-July), affected by herbicide application. Cluster II was formed by 22 lowland cropped plots mostly with direct seeding and herbicide application surveyed in the wet period but on still rather dry ground. Cluster III contained mainly mid-elevation cropped fields surveyed in the dry period. Cluster IV comprised mid-elevation plots cropped with transplanted rice plants in the wet period. Cluster V included mostly lowland cropped plots with transplanted rice plants and herbicide application surveyed in the wet period. Cluster VI comprised mostly mid-elevation plots with 
transplanted rice. In clusters III, IV and VI, the proportion of paddy fields with herbicide treatment was much lower than in the other clusters.

The first rice cropping period begins usually early in the rainy season when much water is available to enhance the growth of the rice plants. We observed that the water level on paddy fields in this period varied from 0 to $7 \mathrm{~cm}$ above soil surface. There was much regional variation but in some plots soils were still very dry because the rain started late, reflected especially by the clusters I and II (Table 4). Clusters III-VI comprised mainly flooded paddy fields.

Soil physical analysis showed that all examined plots had high clay content.Variation in soil $\mathrm{pH}$ was rather low ranging from 6.2 to 6.6. Organic $\mathrm{C}$ and $\mathrm{N}_{\text {total }}$ were slightly lower in cluster II than in the other clusters. The organic C content of all clusters ranged from $1.2 \%$ to $2.4 \%$.

The results of NMDS demonstrated the relationship between the species composition and environmental factors. The first ordination axis, reflecting the principal floristic gradient, corresponded to an elevation gradient, with sample scores of higher altitudes and water depth (wtrdpth) such as of cluster III occurring in the right part of the diagram (Fig. 4a). The vector (hrbapl) opposed to altitude shows that herbicides were much more commonly applied on the lowland fields than on mid-elevation fields. Water depth being opposed to cropping status (cltvnstt) indicates that the rice fields were ploughed and flooded but, after harvest, left intermittently fallow under dry or moderately wet conditions. The second ordination axis is more difficult to interpret but corresponded to cropping status (cltvnstt) and, to a lesser degree, to the cropping period (season).

Table 4 Environmental and cultivation characteristics of the six weed communities

\begin{tabular}{|c|c|c|c|c|c|c|c|c|c|c|c|}
\hline \multirow{3}{*}{ Cluster } & \multirow{3}{*}{$\mathrm{n}$} & \multicolumn{2}{|c|}{ Altitude } & \multicolumn{2}{|c|}{$\begin{array}{l}\text { Cropping } \\
\text { period }\end{array}$} & \multicolumn{2}{|c|}{$\begin{array}{l}\text { Plant } \\
\text { establishment } \\
\text { methods }\end{array}$} & \multicolumn{2}{|c|}{$\begin{array}{l}\text { Cropping } \\
\text { status }\end{array}$} & \multirow[b]{2}{*}{$\begin{array}{l}\text { Herbicide } \\
\text { application }\end{array}$} & \multirow[b]{2}{*}{$\begin{array}{l}\text { Water } \\
\text { depth }\end{array}$} \\
\hline & & $\begin{array}{l}\text { Low- } \\
\text { land }\end{array}$ & $\begin{array}{l}\text { Mid- } \\
\text { elevation }\end{array}$ & $\begin{array}{l}\text { Oct- } \\
\text { Jan }\end{array}$ & $\begin{array}{l}\text { May- } \\
\text { Jul }\end{array}$ & $\mathrm{TF}$ & DSF & $\mathrm{C}$ & $\mathrm{F}$ & & \\
\hline & & \multicolumn{6}{|c|}{$\%$} & & & & $\mathrm{~cm}$ \\
\hline I & 25 & 80 & 20 & 24 & 76 & 40 & 60 & 48 & 52 & 80 & $0.1 \pm 1.7$ \\
\hline II & 22 & 100 & 0 & 91 & 9 & 30 & 70 & 77 & 23 & 77 & $0.5 \pm 1.5$ \\
\hline III & 56 & 29 & 71 & 23 & 77 & 96 & 4 & 93 & 7 & 30 & $1.2 \pm 1.3$ \\
\hline IV & 22 & 32 & 68 & 86 & 13 & 100 & 0 & 82 & 18 & 23 & $1.0 \pm 1.3$ \\
\hline V & 39 & 69 & 31 & 74 & 26 & 95 & 5 & 87 & 13 & 69 & $0.9 \pm 1.8$ \\
\hline VI & 34 & 21 & 79 & 65 & 35 & 100 & 0 & 53 & 47 & 18 & $0.8 \pm 1.6$ \\
\hline
\end{tabular}

Abbreviations: $\mathrm{TF}=$ transplanted; $\mathrm{DSF}=$ direct seeding; $\mathrm{M}=$ manual weeding; $\mathrm{H}=$ herbicide application; $\mathrm{C}=$ cultivated; $\mathrm{F}=$ fallow 


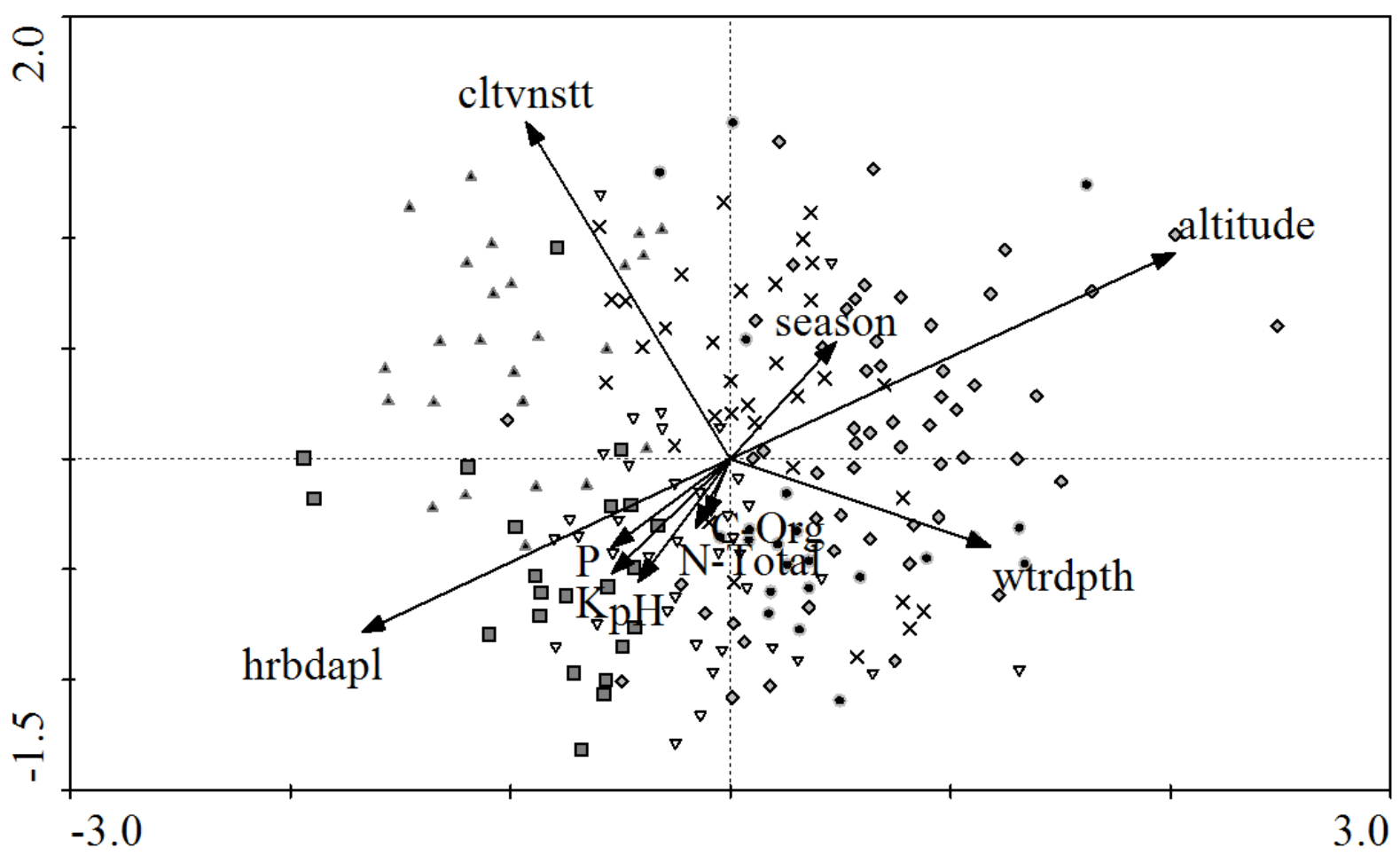

Figure 4a Nonmetric Multi-Dimensional Scaling (NMDS) ordination showing the classified sample and passively projected environmental factors

Many species depend on the specific water conditions in the paddy fields (Fig 4b). Aquatic rice weeds such as $A$. pinnata, $P$. stratiotes and Salvinia adnata, together with $M$. vaginalis, were placed in the right axis part of the diagram. Most Poaceae and Asteraceae were crowded in the left part of the diagram. A water level below-ground, best represented in cluster I, supported a plant composition in which grass weeds such as L. chinensis prevail.

Several factors influence the species composition and richness of plant communities in paddy fields. In the present study, we observed effects of altitude, herbicide application, water level, cropping period, cultivating methods and soil properties. 


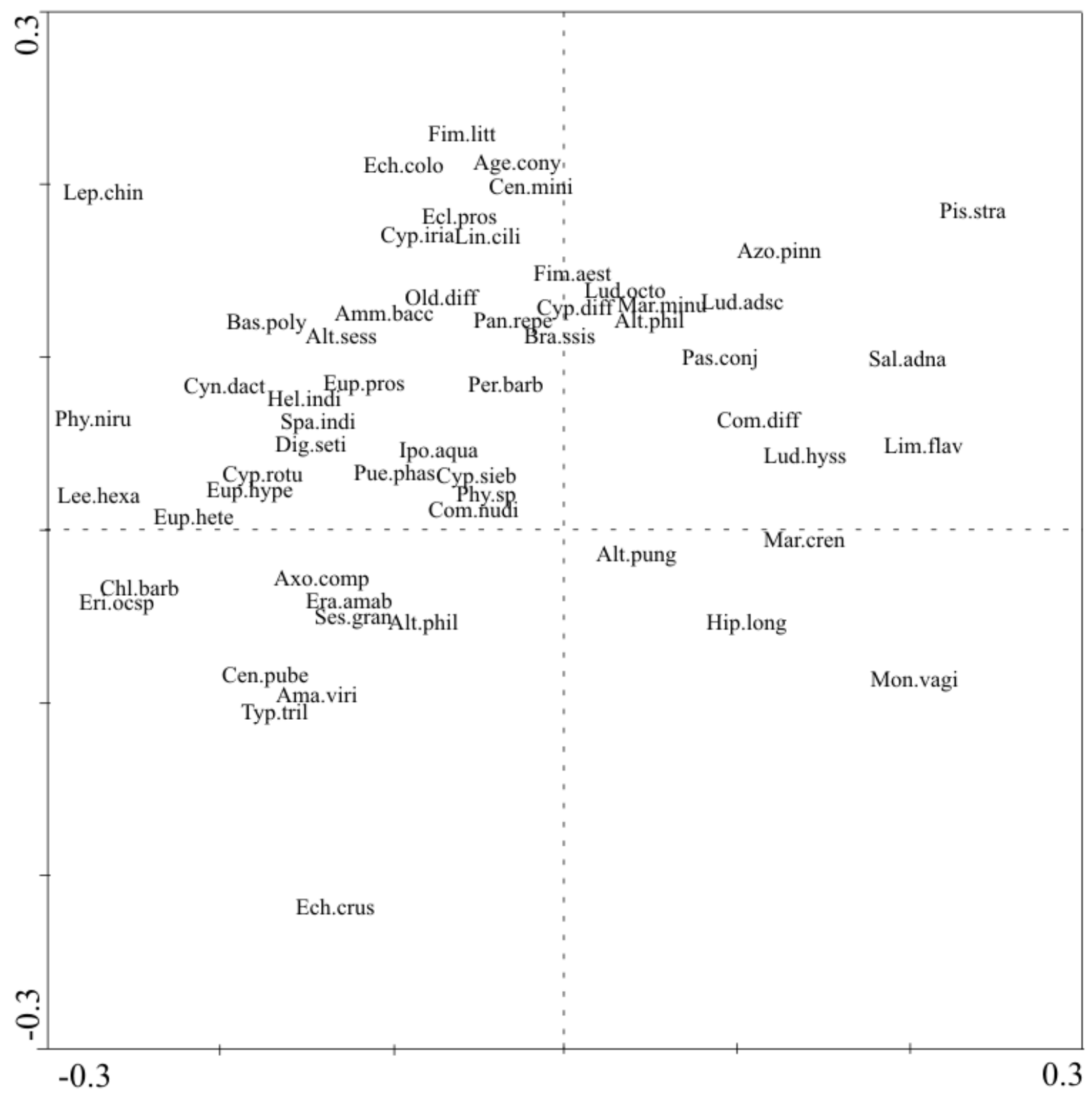

Figure 4b Nonmetric Multi-Dimensional Scaling (NMDS) ordination showing scores of 56 selected species; wtrdpth $=$ water depth, cltvnstt $=$ cultivation status, hrbapl $=$ herbicide application, $\mathrm{pH}=$ soil acidity, $\mathrm{P}=$ phosphor content in soil, $\mathrm{K}=$ potassium content in soil, $\mathrm{N}$-Total $=$ total nitrogen content in soil, $\mathrm{C}$-Org $=$ organic $\mathrm{C}$ content in soil; $\boldsymbol{\Lambda}$, cluster 1 ; $\mathbf{\square}$, cluster 2 ; $\diamond$, cluster 3 ; $\bullet$, cluster 4 ; $\nabla$, cluster 5 ; $\times$, cluster 6 . Abbreviations of species names are given in Tables 2 and 3. Abbreviated names not found there: Era.amab=Eragrostis amabilis (L) Wight \& Arn; Ses.gran=Sesbania grandiflora (L.) Pers.Discussion 


\section{Discussion}

\section{Effects of altitude on weed composition}

Yakup (2007) found that weed communities in paddy fields in West Java depend on the cropping period and on environmental conditions, with the weed diversity peaking at 300-700 $\mathrm{m}$ a.s.l. Shrestha et al. (2012) noted that the climatic minimum factor for plants in midelevation areas is (relatively low) air temperature, while in the lowlands temperature and rainfall amounts were crucial. We found that the number of weed species in mid-elevation paddy fields per plot was almost $40 \%$ higher compared to that of lowland areas. The difference in species pool size between mid-elevation and lowland weed floras on the regional level is emphasized on the local and plot level by effects of management. Rain and field hydrology influence the water level which itself effect the period of cultivation and weeding habits. With high water level to control weeds as chiefly in mid-elevation areas no or reduced herbicide application was observed. Post-harvest intermittent fallows which may be dry or moderatelywet, supported a vegetation richer in grasses than that of flooded fields.

\section{Implication of water management and cropping status}

Weed growth depends on water availability (Kamoshita et al., 2010). In our study water level had a noticeable effect on the species composition. A persistently high water level in paddy fields was indicated by an abundance of hydrophytes while grasses and certain herbs dominated under conditions of low water level. In the rainy season, farmers control the water level and the duration of flooding in paddy fields not only to support the growth of the rice plants but also to control weed growth. Our findings are consistent with Juraimi et al. (2011) who suggest that periods of flooding on paddy fields suppress grasses more than broadleaved plants and sedge weeds. De Vries et al. (2010) found that in Senegal flooding brought about the same effect as herbicide application and one manual weeding, and Tomita et al. (2003b) reasoned that high water levels affect the plant diversity because germination of terrestrial weeds is inhibited.

The water level in paddy fields during the cropping period and water storage in reservoirs depend chiefly on the amount of rainfall and the length of the wet season (Purnama, 2008). In recent years, in the lowlands of Java the water availability in irrigation systems decreased by more than $60 \%$ in the dry season (Sumarno et al., 2008). The climate and hydrology in lowland areas do not support multiple flooding cycles per year. Fields are submerged only during the rainy season and dry conditions obtain during the rest of the year (Purnama, 2008). 
Similar to previous research (Yakup 2007; Tomita 2003b), we found differences in community composition and species abundance between cropping periods, i.e. depending on the status of land preparation and water conditions. Moreover, in post-harvest fallows weed cover and diversity were higher than on cropped fields. The time of fallow in paddy fields is important for soil micronutrient maintenance, such as Cu, Zn and Fe (Wang et al., 2011) and the macronutrient (nitrogen) cycle (Becker et al., 2007). In West Java, farmers prefer to let their land lie fallow in the dry season, due to lack of water. Although the Jatiluhur dam was designated to foster intensive cultivation methods in the whole lowland area, irrigation systems remained highly dependent on rainfall (Hussain et al., 2006).

\section{Implication of weed management}

Similar to Pane et al. (2002), we observed that farmers manually weeded the fields twice in all areas, the first time around 20 days and the second time about 40 days after transplanting. Our data showed a negative correlation between herbicide application and weed species numbers in lowland paddy fields. Farmers used herbicides in most lowland plots, as reflected in clusters I (80\%) and II (77\%), usually in the end of the dry season to deplete the weeds that grow on the fallow land. Under dry conditions which favour grasses and broadleaved plants pre-cultivation herbicide usage is increasing, especially in lowland areas. Compared to manual weeding, herbicide treatment in the dry season in the lowlands resulted in better crop yields (Akobundu, 1981) and reduced the biomass of weeds by about 50-60\% and the weed density by 10-70\% (Chauhan \& Opena, 2012). Phuong et al. (2005) stated that herbicidebased weed control in directly seeded lowland fields increased the rice grain yield by up to $20 \%$ in the dry season and by up to $38 \%$ in the wet season.

As in our study herbicide use was common in the lowlands but rare in the midelevation areas, the effects of climate and herbicide use could not be entirely disentangled. Moreover, different active compounds in herbicides affect different weed species. According to Vasileiadis et al. (2012) herbicide application had major effects on the densities of annual broad-leaved weed species, and lesser on annual and perennial grass weeds. Watanabe (2011) reviewed that the plant diversity in present paddy fields in Japan was reduced by $75 \%$ compared to the species diversity found in the 1940s. Apart from the reduced species diversity, potential negative effects of herbicides on food production and the environment should not be disregarded (Kudsk \& Streibig, 2003; Brimner, 2005), nor detrimental effects of herbicide resistance through long-time application (Olofsdotter et al., 2000). 


\section{Acknowledgements}

This paper could be prepared thanks to Erasmus Mundus Experts Asia (mobility program) and was funded by BIOTROP (PhD grant 2012 to NRK). We would like to thank Dr. Sri S. Tjitrosoedirdjo for every support on our field work and laboratory research. We are also grateful to the editor's and reviewer's constructive comments on an earlier version of the manuscript.

\section{References}

AKOBUNDU IO (1981) Weed control in direct-seeded lowland rice under poor water control conditions. Weed Research 21, 273-278.

BACKer CA (1973) Atlas of 220 Weeds of Sugar-cane Fields in Java. Ysel Press, Deventer, NL.

Becker M, Asch F, Maskey SL, Pande KR, Shah SC \& SRestha S (2007) Effects of transition season management on soil $\mathrm{N}$ dynamics and system $\mathrm{N}$ balances in rice-wheat rotations of Nepal. Field Crops Research 103, 98-108.

Boling AA, TuOng TP, SugAnda H, et al. (2008) The effect of toposequence position on soil properties, hydrology, and yield of rainfed lowland rice in Southeast Asia. Field Crops Research 106, 22-33.

BPN (Badan Pertanahan Nasional)(2013) Peta Online Badan Pertanahan Nasional. Available at: http://peta.bpn.go.id/ (last accessed 15 September 2013)

BRIMNER T, GALLIVAN GJ \& STEPHENSON GR (2005) Influence of herbicide-resistant canola on environmental impact of weed management. Pest Management Science 61, 47-52.

Chauhan BS \& Opena J (2012) Effect of tillage systems and herbicides on weed emergence, weed growth and grain yield in dry seeded rice systems. Field Crops Research 137, 56-69. 
D’ARRIGo R \& SMERDON JE (2008) Tropical climate influences on drought variability over Java. Indonesia. Geophysical Research Letters 35, 1-5.

de Vries Me, Rodenburg J, Bado BV, Sow A, LeffelaAr PA \& Giler KE (2010) Rice production with less irrigation water is possible in a Sahelian environment. Field Crops Research 116, 154-164.

Harada J, PAisooksantivatana Y \& Zungsontiporn S (1987) Weeds in the Highlands of Northern Thailand: Color Illustrated. National Weed Science Research Institute Project, Bangkok, TH.

Hussain I, Wijerathna D, Arief SS, Murtiningrum, Mawarni A And Suparmi (2006) Irrigation productivity and poverty linkages in irrigation systems in Java, Indonesia. Water Resources Management 20, 313-336.

Inamura T, Miyagawa S, Singvilay O, Sipaseauth N And Kono Y (2003) Competition between weeds and wet season transplanted paddy rice for nitrogen use, growth and yield in the central and northern regions of Laos. Weed Biology and Management 3, 213-221.

Indonesian National Development Planning Board (2003) Profile of Indonesian Food and Agriculture. Bappenas, Jakarta, ID. Available at: www.bappenas.go.id/get-fileserver/node/541/ (last accessed 05 August 2013).

Johnson DE, Wopereis MCS, Mbodj D, Diallo S, Powers S \& Haefele SM (2004) Timing of weed management and yield losses due to weeds in irrigated rice in the Sahel. Field Crops Research 85, 31-42.

Juraimi AS, SAIfUl AHM, UdDin MK, ANUAR AR \& AzMi M (2011) Diversity of weed communities under different water regimes in bertam irrigated direct seeded rice field. Australian Journal of Crop Science 5, 595-604.

KAmoshitA A, IKEDA H, YAmAgishi J \& OUK M (2010) Ecophysiological study on weed seed banks and weeds in Cambodian paddy fields with contrasting water availability. Weed and Biology Management 10, 261-272. 
KudSK P \& StREIBIG JC (2003) Herbicides - a two-edged sword. Weed Research 43, 90102.

Kumalasari NR, AbDullah L \& Bergmeier E (2014) Nutrient assessment of paddy weeds as ruminant feed in Java. Livestock Research for Rural Development 26, 59.

LARNEY FJ \& BLACKSHAW RE (2003) Weed seed viability in composted beef cattle feedlot manure. Journal Environmental Quality 32, 105-113.

LEPŠ J \& ŠMILAUER P (1999) Multivariate Analysis of Ecological Data. Faculty of Biological Sciences, University of South Bohemia, České Budějovice, CZ.

MAUlidA DAR \& ARISOesilaningsiH (2013) Dynamic of wild vegetation community structure and black rice growth in organic paddy field, Kecamatan Kepanjen Malang. Jurnal Biotropika 1, 19-23.

McCune B \& GRACE JB (2002) Analysis of Ecological Communities. Gleneden Beach: MjM Software Design, Oregon, USA.

Moody K, Munroe CE, Lubigan RT \& Paller EC JR (1984) Major Weeds of the Philippines. Weed Science Society of the Philippines, Laguna, PH.

Olofsdotter M, VAlverde BE \& MAdsen KH (2000) Herbicide resistant rice (Oryza sativa L.): Global implications for weedy rice and weed management. Annals of Applied Biology 137, 279-295.

Phuong LT, Denich M, Vlek PLG \& Balasubramanian V (2005) Suppressing weeds in direct seeded lowland rice: Effects of methods and rates of seeding. Journal of Agronomy and Crop Science 191, 185-194.

Pane H \& JAtmiko SY (2009) Pengendalian gulma pada tanaman padi. Available at: http://www.litbang.deptan.go.id/special/padi/bbpadi_2009_itp_10.pdf (last accessed on 28 March 2014). 
Pane H, Noor ES, Susanti Z \& Mortimer M (2002) Weed characterization in Walik Jerami rice in rainfed lowland area. Penelitian Pertanian Tanaman Pangan 21, 6-14.

PuRnama S (2008) The potential of rainfall and its impact to groundwater storage in Java Island. Indonesian Journal of Geography 40, 153-166.

Rodenburg J, Saito K, Kakai RG, Toure A, Mariko M \& Kiepe P (2009) Weed competitiveness of the lowland rice varieties of NERICA in the southern Guinea Savanna. Field Crops Research 114, 411-418.

RoleČeK J, TiChÝ L, ZelenÝ D \& ChytRÝ M (2009) Modified TWINSPAN classification in which the hierarchy respects cluster heterogeneity. Journal of Vegetation Science 20, 596609.

Shrestha A, Knezevic SZ, Roy RC, BALl-Coelho BR \& SWANTON CJ (2002) Effect of tillage, cover crop rotation on the composition of weed flora in a sandy soil. Weed Research 42, 76-87.

Shrestha S, Asch F, Dussere J, Ramanantsoanirina A \& Brueck H (2012) Climate effects on yield components as affected by genotypic responses to variable environmental conditions in upland rice systems at different altitude. Field Crops Research 134, 216-228.

SOEKISMAN T (2010) Integrated management of paddy and aquatic weeds in Indonesia. Available at: http://www.agnet.org/htmlarea_file/library/20110721174434/eb367b.pdf (last accessed 20 June 2013).

Soerjani M, Kostermans AJGH \& Tuttrosoepomo G (1987) Weeds of Rice in Indonesia. Balai Pustaka, Jakarta, ID.

SUKRISTIYONUBOWO (2007) Nutrient balances in terraced paddy fields under traditional irrigation in Indonesia. PhD thesis. Faculty of Bioscience Engineering. Ghent University. Ghent. BE. 
SumARno (2008) Periodisasi musim tanam padi sebagai landasan manajemen produksi beras nasional. [Periodization of rice cropping period as a base of national production management] Available at: http://pustaka.litbang.deptan.go.id/bppi/lengkap/st080206-1.pdf (last accessed 19 March 2014).

Sumarno, WARgiono J, Kartasasmita UG, Hasanuddin A, SoEJitno \& Ismail IG (2008) Anomali Iklim 2006/2007 dan Saran Kebijakan Teknis Pencapaian Target Produksi Padi. [Climate anomaly 2006/2007 and technical policy advices for the rice production target.] Iptek Tanaman Pangan 3, 69-97.

The Plant List (2010). Version 1. Available at: http://www.theplantlist.org/ (last accessed 30 November 2013).

TOMitA, S., E. NAwATA, Kono Y, et al (2003a) Differences in weed vegetation in process to cultivating methods and water condition in rainfed paddy fields in north-east Thailand. Weed Biology and Management 3, 117-127.

TOMita S, MiYagawa S, Kono Y, et al (2003b) Rice yield losses by competition with weeds in rainfed paddy fields in north-east Thailand. Weed Biology and Management 3, 162171.

TUKIDIN (2010) Character of rainfall in Indonesia. Jurnal Geografi 7, 136-145.

VAN DER MAAREL E (2005) Vegetation Ecology. Blackwell, Oxford, UK.

VASILEIADIS VP, Froud-WILliams RJ \& ElefthEROHORINOS IG (2012) Tillage and herbicide treatments with inter-row cultivation influence weed densities and yield of three industrial crops. Weed Biology and Management 12, 84-90.

Wang Q, Bai J, Huang L, Deng W, Xiao R \& Zhang K (2011) Soil nutrient distribution in two typical paddy terrace wetland along an elevation gradient during the fallow period. Journal of Mountain Science 8, 476-483.

WATANABE H (2011) Development of lowland weed management and weed succession in Japan. Weed Biology and Management 11, 175-189. 
WILDi O (2010) Data analysis in vegetation ecology. Wiley-Blackwell, Oxford, UK.

YAKUP (2007) Study on spatio temporal dynamics of weed communities in paddy field landscape of Ciliwung-Cisadane watershed. PhD thesis, Institut Pertanian Bogor, Bogor, ID. 


\section{Effects of surrounding crop and semi natural vegetation on the diversity of paddy field weeds}

N R KUMALASARI* \& E BERGMEIER*

under review in Agriculture and Food Security

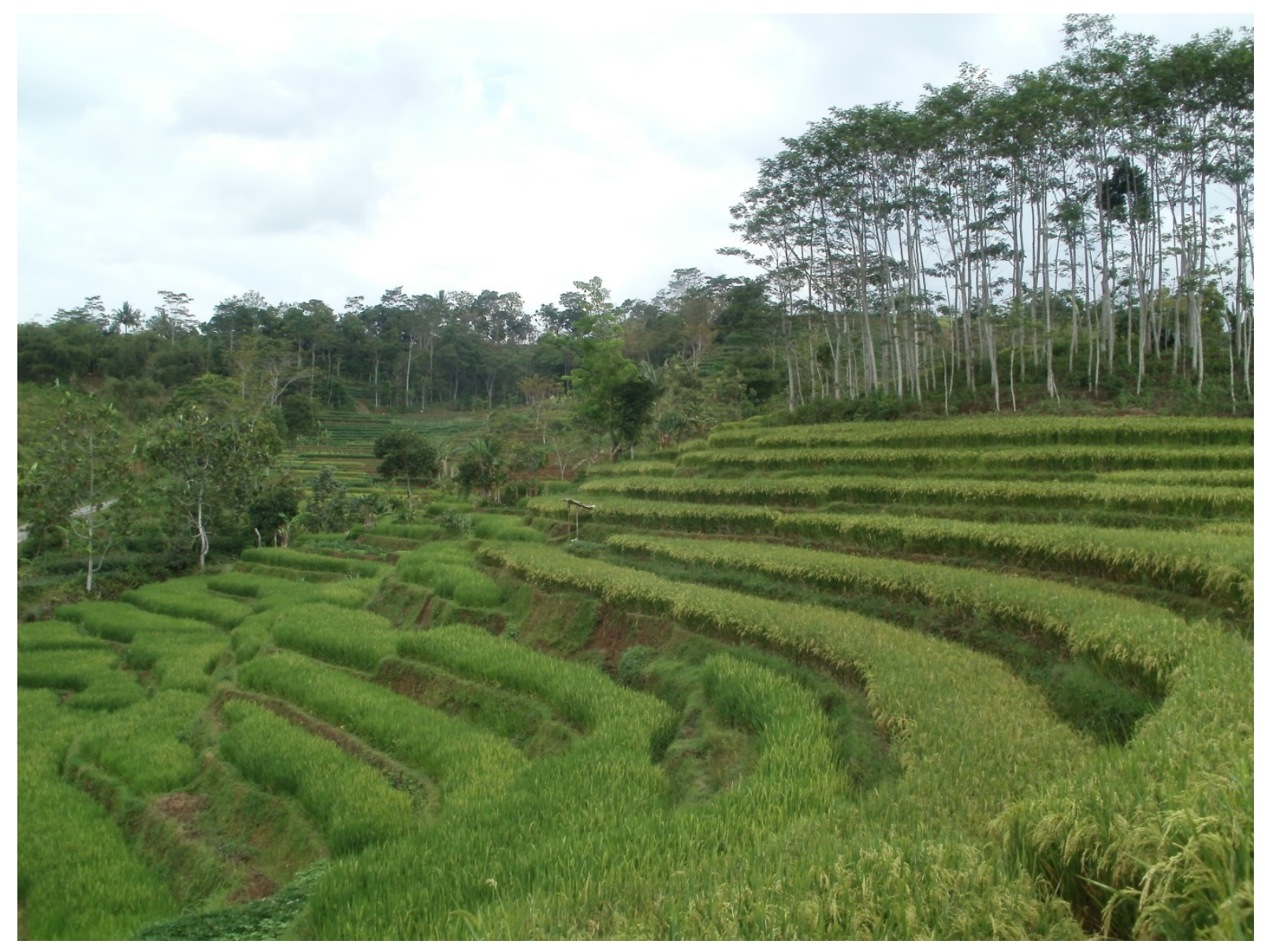




\begin{abstract}
The ecosystems around paddy fields in Java are varied, owing to differences in climate, altitude and traditional farming varies across villages. This study examines the effects of different types of surrounding vegetation on the plant diversity in paddy fields. We studied sites in six areas in the island of Java, Indonesia, i.e. Cugenang, Karanganyar, Malang (400$850 \mathrm{~m}$ asl), Karawang, Brebes and Gresik (10-50 m asl). Samples of vegetation were taken in a period from October 2011 through to June 2012. Each site comprised 33 plots of paddy fields, $20 \mathrm{~m}^{2}$ in size and bunds $10 \mathrm{~m}^{2}$ in size. We used Analysis of Variance Matrix Unbalanced to analyze the effect of the sample sites, complexity, location and season on weed composition. Tukey's HSD test was performed to determine significant differences between groups in the sample. The peak of rice cultivation in Java is around the first cultivation season between October and February. We recorded 14 crop species and 221 non-crop plant species (weeds), of which 171 species occurred in paddy fields and 190 on bunds. Species numbers in upland areas were higher than in lowland areas. In fallows, twice as many species as in cultivated rice fields were found. In contrast, the presence of semi-natural vegetation within short distance had no significant effect on weed species numbers in paddy fields. Altogether, differences in weed species numbers and composition between areas are more pronounced than the effects of local environmental complexity.
\end{abstract}

Keywords: simple environment, complex environment, cultivation season, multi-crop, monoculture, horticulture, fallow, cultivated, bund, landscape 


\section{Introduction}

Environmental factors and management are the most important general drivers of weed species richness, abundance and composition in agro-ecosystems (e.g., Donald, 2004; Espinosa-García et al., 2004; Dornelas et al., 2009; Otto et al., 2012). Weed communities differ in relation to environmental and landscape structural heterogeneity (Dornelas et al., 2009; Gaba et al., 2010), and even the seedbanks in arable lands are influenced by landscape complexity (José-Marìa and Sans, 2011).

The ecosystems around paddy fields in Java are varied, owing to differences in climate and altitude and because traditional farming varies across villages. Available resources and the local natural environmental conditions, such as season, water availability, landscape and natural vegetation, determine the type and complexity of land use. For instance, in the rainy season water availability is increased both in irrigated and rain-fed paddy fields, a factor that is important for rice plant growth and weed management (IRRI, 1984).

Javanese rice farmers commonly divide a year in three rain-dependent cultivation seasons. The prime cultivation (between the ends of October till March) starts in the wet season, the second around April-July is the medium-wet season, and the third is the dry season between August and October (Sumarno, 2008). An optimum cultivation date is indicated by the soil moisture level required for planting and in general by the water availability to be expected in the coming period (Tazhibayeva and Townsend, 2012). Compared with 1961 - 1970, the length of the rainy season, the number of dry and wet months and the amount of rainfall in each season differed in the period after 1991 (Pramudia, 2006), and so there was a shift in timing of rice planting and cultivation management.

To remain competitive and to provide food, feed, and industrial crops to satisfy the increasing demands of people, smallholder rice farmers in Java commonly practice intercropping or multiple cropping (polycultures). They cultivate two or more crops per year on the same land, thereby improving income maintenance in the countryside (Godoy and Bennet, 1991). Intercropping and multiple cropping have a favorable effect on sustainable agriculture (Newton et al. 2009), as soil fertility is increased (Prasad and Umar, 1990; SaeLee et al., 1992; Chamanabad et al., 2007) and weed infestation prevented to some extent. . Intercropping was found to influence the weed composition in adjacent fields and reduced weed densities by two thirds (Rahnavard et al., 2009; but see Gomez and Gurevitch, 1998). Weed seed densities decreased by one third in comparison to continuous cropping (Cardina et 
al, 2002). Owing to the ecology and phenology of plants, weed community composition and density are thus related to intercropping.

This study examines the effects of different types of surrounding vegetation on the plant diversity in paddy fields. The objective was to understand whether the weeds in the paddy fields are influenced by customary multiple-crop systems nearby paddy fields, by the bund vegetation at their margins, and by surrounding semi-natural vegetation. The aim was to provide a scientific basis for developing an integrated weed management strategy for paddy fields.

We hypothesize, first, that weed species numbers and composition in paddy fields and bunds differ, second, that surrounding crops and semi-natural vegetation influence the weed communities.

\section{Material and Methods}

\section{Characteristics of sample sites}

We studied sites in six areas in the island of Java, Indonesia, i.e. Cugenang, Karanganyar, Malang, Karawang, Brebes and Gresik. The first three are representative of upland rice cropping systems (400-850 m asl). In the upland areas, the annual rainfall amounts to 3100$4600 \mathrm{~mm}$ and is concentrated in the period between September and May (Fig. 1). The temperature ranges between $20-27^{\circ} \mathrm{C}$ depending on altitude. The other three study sites are representative of lowland rice cropping systems (10-50 m asl). The annual rainfall of 1300$2550 \mathrm{~mm}$ is mainly during the southwest monsoon between September and April in Gresik and Brebes and from December in Karawang. The temperature ranges from $26-30^{\circ} \mathrm{C}$ (Fig. 1). 

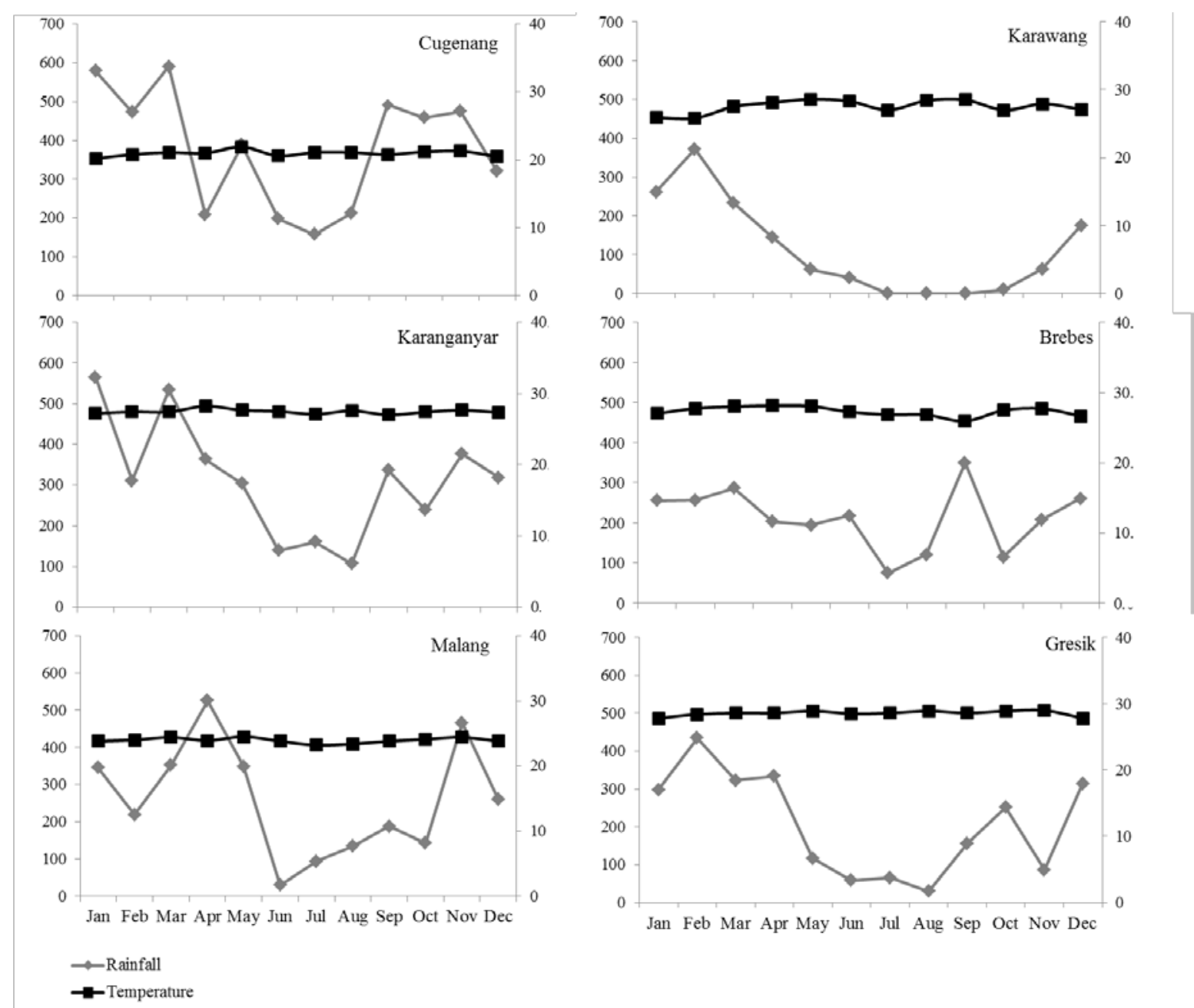

Figure 1 Rainfall and temperature mean values in the study areas in 2011 (left y axis and grey line: rainfall in mm; right y axis and black line: temperature in ${ }^{\circ} \mathrm{C}$ )

\section{Data sampling}

The weed vegetation was surveyed on a regular grid of sample plots in six paddy field sites (each site 5 x $5 \mathrm{~km}$ ), one per area. Samples of vegetation were taken in a period from October 2011 through to June 2012, i.e. including two cultivation seasons October-December and May-June. Total vascular plant species composition was determined per plot. Each site comprised 33 plots of paddy fields, $20 \mathrm{~m}^{2}$ in size, and 33 plots of bunds, $10 \mathrm{~m}^{2}$ in size. Paddy fields were classed as either cultivated or fallow. Bunds divide rice fields to control the water depth. Varying in style with the riverbed slope (Hoshikawa and Kobayashi, 2003), they are at least $20 \mathrm{~cm}$ high and between 15 and $150 \mathrm{~cm}$ wide, with the shape depending on the paddy topography. The water depth is controlled and regulated by the spillway height (around $5 \mathrm{~cm}$ ) (Fig. 2). 
The size of terraces varied depending on topography, contour and ownership, but in flat areas terraces were usually around $50 \mathrm{~m}$ x $100 \mathrm{~m}$. In upland areas of Central Java terraces were between $56 \mathrm{~m}^{2}$ and $176 \mathrm{~m}^{2}$ in size and shaped so as to descending to the river (Sukristiyonubowo, 2007).

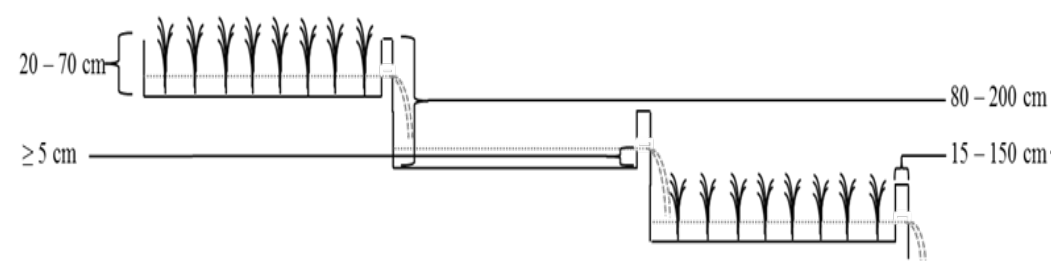

a.

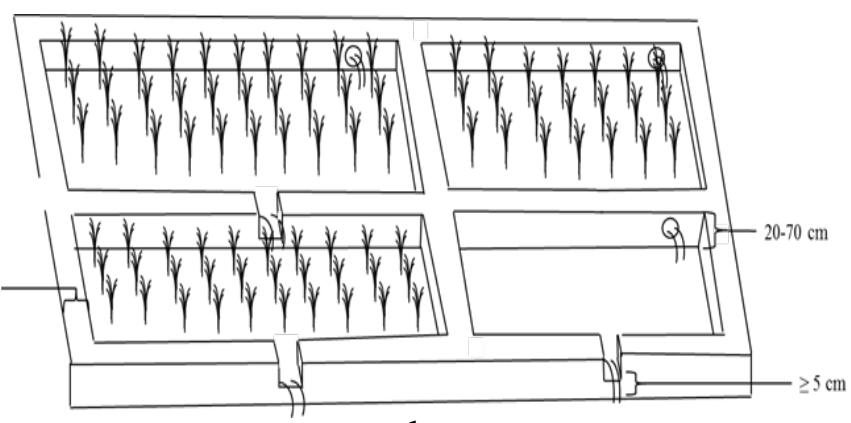

b.

Figure 2 Scheme of bund, terrace and field dimensions of upland (a) and lowland (b) rice fields

On the basis of our survey of the paddy sites, we classed paddy fields, bunds and landscapes as either simple or complex. We noted the distance from the sampled paddy field to the nearest semi-natural vegetation to identify "complex" or "simple" conditions of paddy fields (Tab. 1). “Complex landscape” means farmland where rice has been planted together with other crops in short distance. "Complex bund" is farmland where rice has been planted together with other crops or trees on the bunds. Further, we noted the bund width and plant cover. "Simple" paddy fields, bunds and landscapes are farmlands where rice has been planted without another crop in the fields, on terraces and/or bunds, and with no or distant semi-natural vegetation around.

Table 1 Complexity criteria adopted for paddy fields, bunds and paddy landscape sections

\begin{tabular}{lccc}
\hline & $\begin{array}{c}\text { Semi-natural vegetation } \\
<100 \mathrm{~m} \text { apart }\end{array}$ & $\begin{array}{l}\text { Other crop than rice } \\
<100 \mathrm{~m} \text { apart }\end{array}$ & $\begin{array}{c}\text { Other crop in bund } \\
<100 \mathrm{~m} \text { apart }\end{array}$ \\
\hline Complex paddy field & + & $+/-$ & $+/-$ \\
Complex landscape & - & + & - \\
Complex bund & - & - & + \\
\hline
\end{tabular}

"Other crops" in this work are any arable or horticultural crop plants cultivated in spatial sequence and/or interplanted in the paddy fields or on bunds (Gallaher, 2004), such as corn, mungbean, soybean, chili, onion etc. They form part of polyculture or multiple cropping systems that are commonly and extensively practiced by Indonesian farmers in the dry season. In "semi-natural” vegetation species composition and/or abundance has been altered through anthropogenic disturbances. While no clear natural analogue may be known, they consist of a 
largely spontaneous and native set of plants shaped by ecological and phytogeographical processes (definition modified after Federal Geographic Data Committee, 2008).

\section{Statistical analysis}

This analysis was conducted at the area level, i.e. by considering all weed species surveyed within each area. To reduce statistical noise species present in only one plot in one area were omitted.

We used Analysis of Variance Matrix Unbalanced to analyze the effect of the sample sites, complexity, location and season on weed composition using presence/absence data. We divided the sample plots in three categories, i.e. cultivated paddy fields, fallows and bunds. We determined the complexity in terms of presence or absence of semi-natural vegetation and other crops surrounding the paddy fields (Tab. 1). The "complexity” condition of fields and bunds was ranked 1 = simple or 2 = complex. Similarly, at the landscape level monoculture and multiple cropping were distinguished. Cultivation seasons were $1=$ October-December or 2= May-June.

The effects of the complexity, season and area on rice weed diversity at the field level were analyzed for all weed species. The variables were log- or square-root transformed if necessary to meet the normality requirement for the residual. To determine the key factor(s) affecting weed diversity and quantitative relationships between them, stepwise multiple regression analysis was applied using the criteria of probability of $\mathrm{p}<0.05$ to accept and $\mathrm{p}>0.1$ to remove the variable from the analysis. The analyses were performed in $\mathrm{R} x 64$ 3.0.2 software (R Development Core Team, Vienna, 2013) using the 'Rcmdr' and 'library CAR' package. Furthermore, Tukey’s HSD test was performed to determine significant differences between groups in the sample.

\section{Results}

\section{Characteristics of the paddy field environment}

We mapped seven types of semi-natural vegetation, i.e. conservation forest, bamboo forest, community garden, basin, grassland, fallow and artificial lake vegetation. In terraces and bunds, we found about fourteen different crops planted. In terraces, farmers planted horticultural plants, viz. cassava, mungbean, soybean, chili, tomato, onion, sugarcane and corn. On cropped bunds, the farmers planted trees and grass for animal feed and own 
consumption, such as banana, coconut, guava, Sesbania grandiflora, Setaria spachelata var. splendida and Pennisetum purpureum.

Table 2 Environment types of paddy fields in each area

\begin{tabular}{|c|c|c|c|c|c|c|c|}
\hline & $n$ & Cugenang & Karawang & Karanganyar & Brebes & Malang & Gresik \\
\hline & & 33 & 33 & 33 & 33 & 33 & 33 \\
\hline \multicolumn{8}{|l|}{ Type of field (\%) } \\
\hline Simple & 94 & 51.5 & 66.7 & 33.3 & 51.5 & 42.4 & 39.4 \\
\hline Complex & 104 & 48.5 & 33.3 & 66.7 & 48.5 & 57.6 & 60.6 \\
\hline $\begin{array}{l}\text { Mean distance of } \\
\text { complex field to semi- } \\
\text { natural vegetation (m) }\end{array}$ & & $46.3 \pm 33.3$ & $37.3 \pm 22.3$ & $39.1 \pm 29.6$ & $61.3 \pm 38.4$ & $40.3 \pm 32.0$ & $48.6 \pm 37.2$ \\
\hline \multicolumn{8}{|l|}{ Type of landscape (\%) } \\
\hline Monoculture & 73 & 18.2 & 81.8 & 36.0 & 33.3 & 36.0 & 15.2 \\
\hline Multiple crop & 125 & 81.8 & 18.2 & 64.0 & 66.7 & 64.0 & 84.8 \\
\hline $\begin{array}{l}\text { Multiple crop: mean } \\
\text { distance to other crops } \\
\text { (m) }\end{array}$ & & $6.2 \pm 9.3$ & $5.7 \pm 4.4$ & $14.9 \pm 11.1$ & $19.1 \pm 20.5$ & $7.9 \pm 8.0$ & $4.2 \pm 5.8$ \\
\hline \multicolumn{8}{|l|}{ Type of bund (\%) } \\
\hline Simple & 160 & 80.0 & 100 & 87.9 & 100 & 30.3 & 87.9 \\
\hline Complex & 38 & 20.0 & 0 & 12.1 & 0 & 69.7 & 12.1 \\
\hline Mean bund width $(\mathrm{cm})$ & & $74.5 \pm 32.1$ & $48.8 \pm 22.6$ & $48.6 \pm 24.3$ & $41.1 \pm 10.1$ & $53.3 \pm 24.2$ & $98.0 \pm 62.8$ \\
\hline Bund vegetation cover (\%) & & $64.8 \pm 27.0$ & $26.0 \pm 24.4$ & $59.7 \pm 29.4$ & $32.4 \pm 27.8$ & $61.4 \pm 29.8$ & $65.5 \pm 27.9$ \\
\hline
\end{tabular}

In each area we found various environment types around paddy fields (Tab. 2). In Gresik, most farmers build a special large-sized bund of around $1.5 \mathrm{~m}$ height and 1 - $1.5 \mathrm{~m}$ width, meant to prevent water overflow in the rainy season, to maintain suitable water depth for small-scale fish farming and to keep water until the dry season.

Table 3 Seasonality of paddy field cultivation in the Javanese study areas

\begin{tabular}{lllllllllllll}
\hline Cultivation season & 10 & 11 & 12 & 1 & 2 & 3 & 4 & 5 & 6 & 7 & 8 & 9 \\
\hline $\begin{array}{l}\text { Cugenang } \\
\text { Malang } \\
\text { Karanganyar } \\
\text { Gresik } \\
\text { Brebes } \\
\text { Karawang }\end{array}$ & & & & & & & & & & & &
\end{tabular}

The start of cultivation time varied across Java (Table 3). In upland areas, starting times of the first rice cultivation were around October. In lowland areas, the beginning of cultivation depended on rainfall and water availability. Some farmers in Karanganyar and Brebes cultivated horticultural plants as water was insufficient for rice cultivation in the dry (third) 
season. Commonly, in lowland areas, farmers cultivate rice twice i.e. in the first and second cultivation season. Farmers in Gresik raised fish in their rice fields between January and March at the peak of the rainy season and with water overflow in paddy fields.

\section{Diversity of weeds in paddy fields and bunds}

Overall, we recorded 14 crop species and 221 non-crop plant species (weeds), of which 171 species occurred in paddy fields and 190 on bunds. Only 116 species (52\%) were shared between paddy fields and bunds. Weed communities differed markedly between paddy fields and bunds (Tukey's HSD test: $\mathrm{t}=-11.7925$, $\mathrm{df}=383.841$, $\mathrm{p}$-value $<2.2 \mathrm{e}-16$ ), revealing substantial differences in community composition. Mean weed species numbers in paddy fields were 9.5, whereas on bunds species numbers were significantly higher $(18.4 ; \mathrm{p}<0.05)$.

Plant species numbers differ much between cultivated fields, fallows and bunds (Fig. 3). In fallows, twice as many species as in cultivated rice fields were found. Species numbers in upland areas (Cugenang, Malang and Karawang) were higher than in lowland areas (Brebes, Karawang and Gresik). In contrast, the presence of semi-natural vegetation within short distance had no significant effect on weed species numbers in paddy fields. Species numbers in "complex" bunds and in multiple-crop landscapes were higher than in "simple" bunds and in monoculture landscapes, respectively. Table 4 shows the results of the Analysis of Variance Matrix Unbalanced on the transformed data. Weed species numbers differed markedly between sample categories, areas and seasons, as did the environment complexity categories of landscapes and bunds.

Table 4 Results of the Analysis of Variance Matrix Unbalanced

\begin{tabular}{|c|c|c|c|c|c|c|}
\hline & $\mathrm{Df}$ & Sum Sq & Mean Sq & F value & $\operatorname{Pr}(>F)$ & \\
\hline sample category & 2 & 9299.7 & 4649.9 & 133.4537 & $<2.2 \mathrm{e}-16$ & $* * *$ \\
\hline $\begin{array}{l}\text { field (simple vs. } \\
\text { complex) }\end{array}$ & 1 & 3.3 & 3.3 & 0.0794 & 0.778330 & \\
\hline $\begin{array}{l}\text { landscape (simple } \\
\text { vs. complex) } \\
\text { bund (simple vs. }\end{array}$ & 1 & 216.4 & 216.4 & 5.2796 & 0.022114 & * \\
\hline complex) & 1 & 316.5 & 316.5 & 7.7232 & 0.005720 & $* *$ \\
\hline area & 5 & 4125.9 & 825.2 & 20.1338 & $<2.2 \mathrm{e}-16$ & $* * *$ \\
\hline season & 1 & 352.9 & 352.9 & 8.6111 & 0.003542 & $* * *$ \\
\hline
\end{tabular}



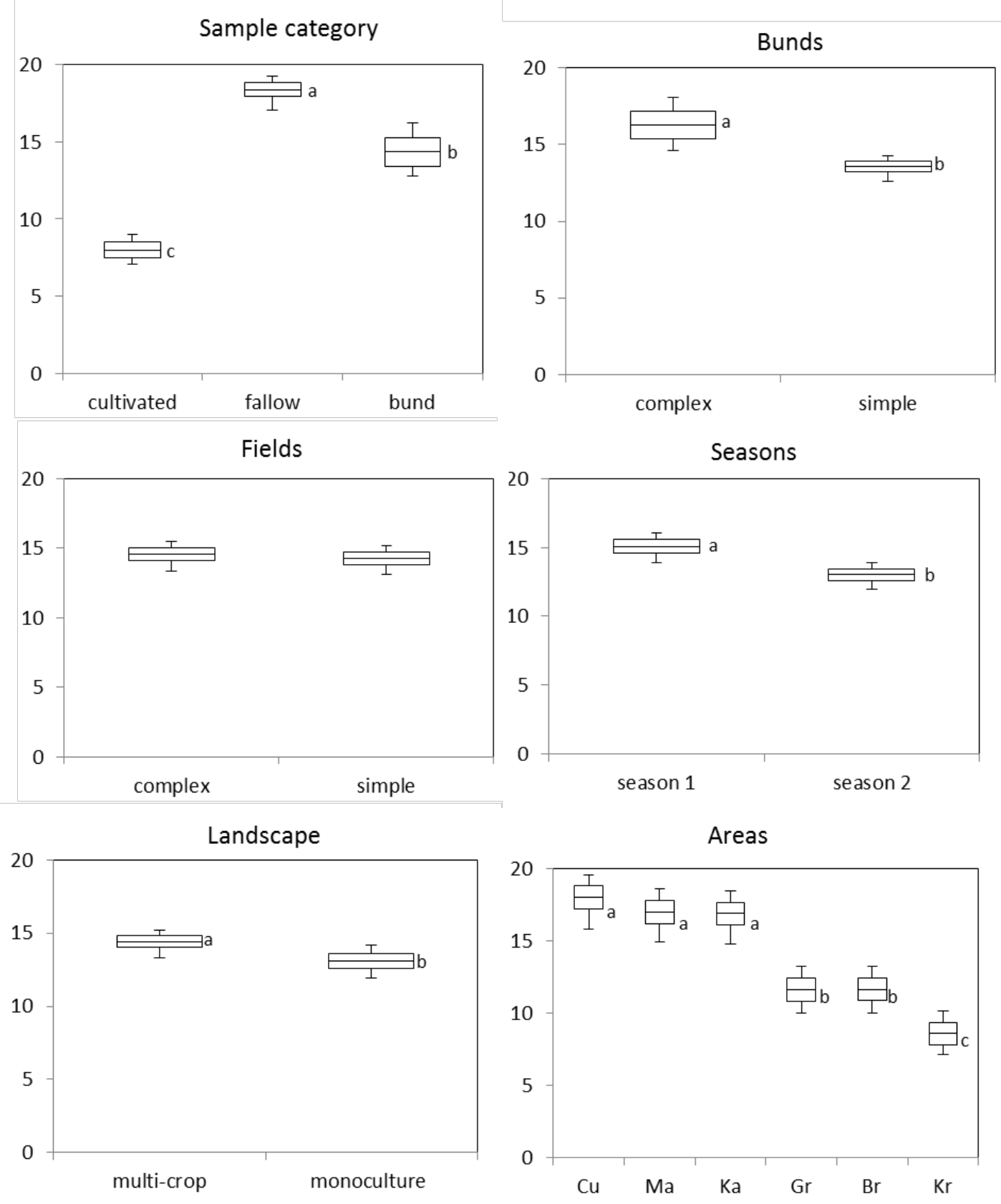

Figure 3 Mean $( \pm S E)$ weed species numbers of sample sites, field types, landscape types, bund types, areas and seasons. $\mathrm{Cu}=$ Cugenang, $\mathrm{Ma}=$ Malang, $\mathrm{Ka}=$ Karanganyar, $\mathrm{Br}=\mathrm{Brebes}$, $\mathrm{Kr}=$ Karawang, $\mathrm{Gr}=\mathrm{Gresik}$

Inspection of all environmental effects showed that weed species numbers were significantly higher in fallow fields with complex landscape and bund, in Cugenang or Malang in the first season (Table 5). The total species number in bunds (190) was higher than in fallow fields (142) and cultivated fields (133).

At the landscape level, multi-crop farming systems around paddy fields resulted in increased species numbers by about $10 \%$ in the paddy fields, compared to monoculture 
systems. Compared to simple bunds, crop cultivation on bunds had a significant effect, with about 25\% higher species numbers in paddy fields (Table 5). The highest species numbers occurred in three upland locations while the lowland area in the district of Karawang had the lowest weed species number.

Table 5 Results of Tukey's HSD test on the weed species numbers in different environments

\begin{tabular}{lr}
\hline Treatments & Mean species numbers \\
\hline Sample category & $7.9 \pm 0.5^{\mathrm{c}}$ \\
Cultivated & $18.4 \pm 0.5^{\mathrm{a}}$ \\
Fallow & $14.4 \pm 0.9^{\mathrm{b}}$ \\
Bund & \\
Landscape & $14.4 \pm 0.4^{\mathrm{a}}$ \\
Multiple crop & $13.1 \pm 0.5^{\mathrm{b}}$ \\
Monoculture & \\
Bund complexity & $16.3 \pm 0.9^{\mathrm{a}}$ \\
Complex & $13.6 \pm 0.4^{\mathrm{b}}$ \\
Simple & \\
Area & $17.9 \pm 0.8^{\mathrm{a}}$ \\
Cugenang & $16.9 \pm 0.8^{\mathrm{a}}$ \\
Malang & $16.9 \pm 0.8^{\mathrm{a}}$ \\
Karanganyar & $11.6 \pm 0.8^{\mathrm{b}}$ \\
Gresik & $11.6 \pm 0.8^{\mathrm{b}}$ \\
Brebes & $8.6 \pm 0.8^{\mathrm{c}}$ \\
Karawang & \\
Season & $15.1 \pm 0.5^{\mathrm{a}}$ \\
season 1 & $13.0 \pm 0.4^{\mathrm{b}}$ \\
season 2 &
\end{tabular}

\section{Discussion}

In Indonesia, bunds are ploughed in and rebuilt each season using the mud of the plough layer to make a boundary between paddy fields, to provide a footpath and control water level (Walker and Rushton, 1986). Our results showed that the weed species numbers on the bunds were significantly different from those in cultivated paddy fields. The presence of crops on bunds was correlated with an increase in weed species numbers in paddy fields, supporting Palmer and Maurer (1997) who found that high diversity in multiple-crop systems promoted the number of weed species. Javanese farmers commonly let weeds grow or cultivate other crops on the bunds. Different crops use different soil resources and have 
different canopy structure, thereby creating microhabitat conditions that may further increase the number of weed species and enhance the differences between weed communities in fields and on bunds. Subudhi et al. (2010) reported that the structure of bunds effected rice yield as well as soil and moisture content. Organic matter, $\mathrm{pH}$ level and nutrients (N, P, K, Ca and $\mathrm{Mg}$ ) were found higher in paddy fields with trees on the bunds, especially legume trees (SaeLee et al., 1992).

Overall infestation of weeds in this study was less in cultivated plots than in the fallows and on the bunds. As Gbanguba et al. (2011), we recorded the highest weed number in fallows. The effects of rice cultivation on weed diversity vary with the production methods applied, whether fields are managed organically or with agrochemicals, and which irrigation and planting systems are used (Donald, 2004). In a review, Navas (2012) concluded that there are two factor groups determining weed diversity, i.e. local environmental conditions (climate, soil, land use history) and crop/treatment related factors (current or preceding crop type, land drainage, fertilization, tillage and herbicide application). Irrigation and its frequency are to be added here ( $\mathrm{Li}$ and Qiang, 2009). We found that cultivated paddy fields in the rainy season serve as a suitable habitat for many hydrophilous plants (Kumalasari, unpubl.).

Contrary to our expectations, weed species numbers in paddy fields were unrelated to the semi-natural vegetation nearby. In contrast, in temperate arable landscapes weed species diversity was influenced by landscape complexity (Roschewitz et al., 2005). There may be an effect though, not studied by us, between paddy weed communities and semi natural vegetation, acting at very short distances. In any case, the influence of adjacent agricultural management, in particular of other crops nearby, on plant species numbers seems to be more pronounced than that of other vegetation formations (see also Gaba et al., 2010).

In the present study, intercropping around paddy fields and on bunds has a considerable effect on weed species numbers (Table 5). Also other researchers reported on the effects of agricultural seasonality, such as fallow management (Awanyo, 2009) and intercropping (Akobundu et al., 1999), on weed species in tropical fields. Demjanová et al. (2009), on the other hand, found that intercropping had no significant influence on weed density and species composition in maize fields. Positive effects of intercropping on organic carbon, soil nitrogen, some micronutrients (Prasad and Umar 1990), total soil nutrients and thus on nutrient uptake (Mohammaddoust-e-Chamanabad et al., 2007) are well-known. As those are essential for plant growth, both crops and weeds profit from multiple-crop systems. 
In Java, rice is grown two until three times per year depending on water availability. The intervening time between harvest and the next rice cultivation varies, meanwhile the land typically lies fallow. The duration of the fallow period is determined by rainfall and may be as short as 3 weeks in the upland areas of Java and up to 16 weeks in the lowlands. Our research showed that season has an effect on species numbers, thus supporting Chauhan and Johnson (2011) in that there was more weed growth in the dry season than in the wet season. In contrast, Saito et al. (2010) reported that weed species numbers were similar in both upland and lowland experiments on paddy fields in West Africa and that there were no large differences in weed pressure between two seasons.

The comparison of paddy weed species numbers at different areas showed that sample category, area and season contribute most to overall species richness. Whether landscapes and bunds are "complex" or "simple” also has an effect on species numbers in paddy fields. Altogether, differences in weed species numbers and composition between areas are more pronounced than the effects of local environmental complexity.

\section{Acknowledgements}

This work was supported through a scholarship from Erasmus Mundus Experts Asia (mobility program) and a PhD grant from BIOTROP (2012). We would like to thank Dr. Sri S. Tjitrosoedirdjo for invaluable support of the field work and laboratory research. We are grateful to Prof. Em. Soekisman Tjitrosemito and Prof. Luki Abdullah for their substantial contributions in designing the field work. Many thanks are also due to Adnan who assisted the data analysis. 


\section{Refferences}

Akobundu, I.O., F. Ekeleme and D. Chikoye. 1999. Influence of fallow management systems and frequency of cropping on weed growth and crop yield. Weed Research. 39. 241-256 Awanyo, L. 2008. Dealing with weedy problems in agriculture: the role of three agricultural land use management practices in the forest-savanna ecological zone of Ghana. Area. 40 (4). 446-458

Cardina, J., C.P. Herms and D.J. Doohan. 2002. Crop rotation and tillage system effects on weed seedbanks. Weed Science. 50. 448-460

Chauhan, B.S. and D.E. Johnson. 2011. Row spacing and weed control timing affect yield of aerobic rice. Field Crops Research. 121. 226-231

Demjanová, E., M. Macák, I. Đalović, F. Majerník, Š. Týr and J. Smatana. 2009. Effects of tillage systems and crop rotation on weed density, weed species composition and weed biomass in maize. Agronomy Research. 7 (2). 785-792

Donald, P.F. 2004. Issues in international conservation: Biodiversity impacts of some agricultural commodity production systems. Conservation Biology. 18 (1). 17 - 37

Dornelas, M., A.C. Moonen, A.E. Magurran and P. Bàrberi. 2009. Species abundance distributions reveal environmental heterogeneity in modified landscapes. Journal of Applied Ecology. 46. 666-672

Espinosa-García, F.J., J.L. Villaseñor and H. Vibrans. The rich generally get richer, but there are exceptions: Correlations between species richness of native plant species and alien weeds in Mexico. Diversity and Distributions. 10. 399-407

Federal Geographic Data Committee. 2008. National Vegetation Classification Standard. Version 2. Federal Geographic Data Committee Vegetation Subcommittee. U.S. Geological Survey. Virginia

Gaba, S., B. Chauvel, F. Dessaint, V. Bretagnolle and S. Petit. 2010. Weed species richness in winter wheat increases with landscape heterogeneity. Agriculture, Ecosystems and Environment. 138. 318-323

Gallaher, R.N. 2004. Multiple cropping systems. Management of Agricultural, Forestry and Fisheries Enterprises. Vol. 1. UNESCO Encyclopedia of Life Support System. Available at http://www.eolss.net/Eolss-sampleAllChapter.aspx (last accessed on 10 March 2014) 
Gbanguba, A.U., U. Ismaila, M.G.M. Kolo and A.Umar. 2011. Effect of cassava/legumes intercrop before rice on weed dynamics and rice grain yield at Badeggi, Nigeria. African Journal of Plant Science. 5 (4). 264-267

Godoy, R. and C.P.A. Bennett. 1991. The economics of monocropping and intercropping by smallholders: The case of coconuts in Indonesia. Human Ecology. 19 (1). 83 - 97

Gomez, P and J Gurevitch. 1998. Weed community responses in a corn-soybean intercrop. Applied Vegetation Science. 1. 281-288

Hoshikawa, K. and S. Kobayashi. 2003. Study on structure and function of an earthen bund irrigation system in Northeast Thailand. Paddy Water Environment. 1. 165-171

IRRI. 1984. Cropping systems in Asia: On-Farm Research and Management. International Rice Research Institute. Los Banos.

José-Marìa, L. and F.X. Sans. 2011. Weed seedbanks in arable fields: effects of management practices and surrounding landscape. Weed Research. 51. 631-640

Li, R.H. and S. Qiang. 2009. Composition of floating weed seeds in lowland rice fields in China and the effects of irrigation frequency and previous crops. Weed Research. 49. 417-427

Mohammaddoust-e-Chamanabad, H.R., A. Asghari and A.M. Tulikov. 2007. The effects of weed-crop competition on nutrient uptake as affected by crop rotation and fertilizers. Pakistan Journal of Biological Sciences. 10 (22). 4128-4131

Navas M.L. 2012. Trait-based approaches to unravelling the assembly of weed communities and their impact on agro-ecosystem functioning. Weed Research. 52. 479-488

Newton, A.C., G.S. Begg and J.S. Swanston. 2009. Deployment of diversity for enhanced crop function. Annals of Applied Biology. 154. 309-322

Otto S., V.P. Vasileiadis, R. Masin and G. Zanin. 2012. Evaluating weed diversity with indices of varying complexity in north-eastern Italy. Weed Research. 52. 373-382

Palmer, M.W. and T.A. Maurer. 1997. Does diversity beget diversity? A case study of crops and weeds. Journal of Vegetation Science. 8. 235-240

Pramudia, A. 2006. Musim Hujan di Sentra Produksi Padi sudah Berubah [Rainy season was change in rice production centers]. Balai Penelitian Agroklimat dan Hidrologi. Sinar Tani. 20-26

Prasad, B. and S.M. Umar. 1990. Effect of rice based six multiple cropping sequences under two cycles of crop rotations on yield and fertility status of soil. Plant and Soil. 127. 251-258 
Rahnavard, A., Z.Y. Ashrafi, H.M. Alizade and S.Sadeghi. 2009. Studies on the effect of fertilizer application and crop rotation on the weed infested fields in Iran. Journal of Agricultural Technology. 5. 1. 41-50

Roschewitz, I., D. Gabriel, T. Tscharntke and C. Thies. 2005. The effects of landscape complexity on arable weed species diversity in organic and conventional farming. Journal of Applied Ecology. 42. 873-882

Sae-Lee, S., P. Vityakon and B. Prachaiyo. 1992. Effects of trees on paddy bund on soil fertility and rice growth in Northern Thailand. Agroforestry. 18. 213-223

Saito, K., K. Azoma and J. Rodenburg. 2010. Plant characteristics associated with weed competitiveness of rice under upland and lowland conditions in West Africa. Field Crops Research 116. 308-317

Subudhi, C.R., B. Behera and S.K. Samantary. 2010. Field bund structures for production of rice in North Eastern Ghats of Orissa, India. Research Journal of Agricultural Sciences. 1 (4). $475-476$

Sukristiyonubowo. 2007. Nutrient balances in terraced paddy fields under traditional irrigation in Indonesia. PhD thesis. Faculty of Bioscience Engineering. Ghent University. Ghent. Belgium. 184p

Sumarno. 2008. Periodisasi musim tanam padi sebagai landasan manajemen produksi beras nasional. [Periodization of rice cultivation season as a base of national production management] Available at: http://pustaka.litbang.deptan.go.id/bppi/lengkap/st0802061.pdf (last accessed on 19 March 2014)

Tazhibayeva, K. and R. M. Townsend. 2012. The impact of climate change on rice production: Heterogeneity and uncertainty. Working Paper. Available at http://www.robertmtownsend.net/sites/default/files/files/papers/working_papers/Impact ofClimateChangeonRiceYieldsDec2012.pdf (last accessed on 5 March 2014)

Walker, S.H and K.R. Rushton. 1986. Water losses through the bunds of irrigated rice fields interpreted through an analogue model. Agricultural Water Management. 11. 59-73 


\section{Nutrient assessment of paddy weeds as ruminant feed in Java}

N R KUMALASARI, L ABDULLAH*, AND E BERGMEIER

Livestock Research for Rural Development. Volume 26, Article \#59. Available at http://www.lrrd.org/lrrd26/4/kuma26059.html

* Department of Nutrition and Feed Technology, Faculty of Animal Science, Bogor Agricultural University (IPB), Jl. Agatis Kampus IPB Darmaga, 16680, Bogor, Jawa Barat, Indonesia

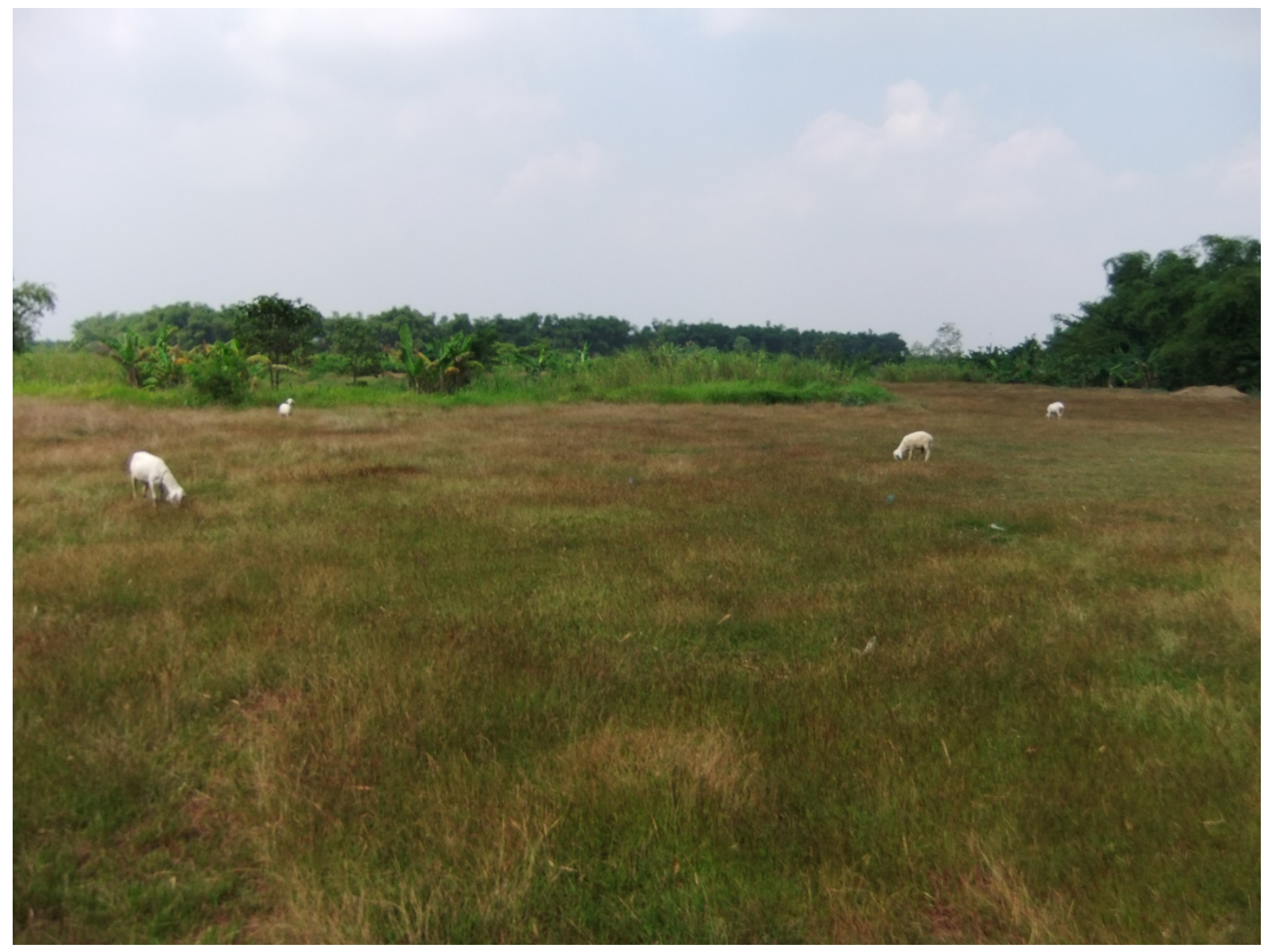




\begin{abstract}
Paddy fields qualify as ruminant feed resources as they produce rice straw and weeds. The main objectives of the present study were to evaluate the productivity and nutrient potential of rice weeds as ruminant feed. The research was conducted in November 2011 and January 2012 in three lowland districts, Karawang, Brebes, and Gresik, and three upland districts, Cianjur, Karanganyar and Malang, on the island of Java, Indonesia. The weeds were collected in cultivated paddy fields, fallows and on paddy field bunds. Weed biomass in upland areas was largest on bunds as a result of intensive weed control in paddy fields. In the lowlands most weed biomass was on fallows. Fresh weed biomass in the first rice growing season (after dry season) yielded $891-2369 \mathrm{~g} / \mathrm{m}^{2}$. Nutrient content revealed a proportion of crude protein between $11.9-16.6 \%$, crude fiber between $31.6-39.6 \%$, and crude fat $0.8-1.1 \%$. Thus, rice weeds have considerable potential as ruminant feed.
\end{abstract}

Keywords: biomass, fat, fallow field, fiber, Indonesia, protein, rice field 


\section{Introduction}

On the island of Java, rice cultivation covers around 5.4 million hectares which equals more than $60 \%$ of the irrigated and intensive farming lands (Bappenas 2003). Weeds are frequently considered as one of the most hampering factors for rice production. Weeds compete with rice for sunlight, nutrients and water, thereby causing yield losses by about 10-50\% (Nyarko \& Datta 1993; Chin et al 2000). Weed management is needed to control weed populations and to reduce undesired effect of farming intensification. On the other hand, as paddy field areas produce rice straw and weeds, they may be important as ruminant feed resources.

Since the 1970s, the Indonesian government introduced herbicides as the main technique to control weeds on paddy fields. However, herbicide application may affect the weed community composition interrelated to crop productivity (Ulber 2010). Herbicide application contributes to reducing weeding labor but affects the environment and ecosystem balance, such as the water system, soil, and non-target organisms. It may cause phytotoxicity (Ueji \& Inao 2001), fish toxicity and weed resistance to herbicides (Matsunaka 2001). Increased intensity of herbicide application has been identified as one of the major drivers for an unbalanced plant composition in paddy field vegetation and of biodiversity loss (Shibayama 2001).

A new approach to biodiversity-friendly management is therefore to enhance benefits derived from desirable weed species with high value for the farmer and the agroecosystem. The use of weed species is possibly the most efficient management to overcome problems of pollution through herbicide usage, weed decomposition or burning.

Morphology, phytomass and species composition of rice weeds vary enormously under different habitat conditions and land use (Soerjani et al. 1987). In traditional farming systems, farmers commonly used weeds as ruminant feed depending on weed properties. Some weeds may be grazed directly by ruminants, others may be cut, harvested and served as fresh feed in a cattle pen.

The feeding value of paddy field weeds is poorly studied and the considerable knowledge of local farmers remains to be recorded. As the knowledge of the nutrient value for most common tropical weeds, especially of their energy value and protein content, are only estimates, there is a lack of information. The main objectives of the present study were to evaluate the yield and nutrient potential of rice weeds that may serve as ruminant feed. 


\section{Materials and methods}

\section{Location}

The research was conducted on the island of Java, Indonesia, on the territory of six districts, Karawang (33-53 m asl), Brebes (26-44 m asl), Gresik (14-41 m asl), Cianjur (527-856 m asl), Karanganyar (403-714 m asl) and Malang (526-684 m asl). Each district represented lowland (0-100 m) and upland areas (>400 m) of rice cultivation in Java. Suitable landscape sections of ca. $5 \mathrm{~km} \mathrm{x} 5 \mathrm{~km}$ size were selected and 15 plots randomized therein.

\section{Weed sampling}

Sampling was done during the rainy season, October 2011 - January 2012. The weeds were collected in cultivated fields, fallows and bunds. Sampling was carried out to coincide with the traditional farming system in representing weeds from paddy field that supplied as ruminant feed. In suitable areas, 15 plots were selected, with each plot of $20 \mathrm{~m}^{2}$ in paddy fields and $10 \mathrm{~m}^{2}$ at bunds. The weed cover in paddy fields and bunds was determined by estimating the percentage of total weed cover. In the same plots, three subplots of $30 \mathrm{~cm} \mathrm{x} 30$ cm were randomly selected to assess weed biomass. Each weed species was identified and counted in the field. Unidentified plants were collected and identified in the laboratory/herbarium. All weeds in the subplots were harvested without soil, leaf litter and other contaminants using a sharp knife. The plant samples were individually weighed as fresh biomass and then mixed. The samples were dried at $60^{\circ} \mathrm{C}$ for $48 \mathrm{~h}$, weighed as dry biomass and then prepared for nutrient analysis.

\section{Nutrient analysis}

The samples were analyzed in the Laboratory of Feed Nutrition, Department Nutrition and Feed Science, Faculty of Animal Science, Bogor Agricultural University. Nutrient analyses used proximate methods. Fiber content was analyzed using the method reported by Goering \& Van Soest (1970) and nitrogen was determined by the Kjeldahl N method.

\section{Results and Discussion}

\section{Weed diversity and availability}

The effect of the farming system on weed diversity and quantity is presented in Table 1. Farmers usually use herbicides or weed manually to control the weed populations in paddy 
fields. In upland areas continuous water supply throughout the year facilitated weed control and the amount of herbicides applied was reduced. Water supply is important as weed growth is distinctly decreased under flooded or submerged condition (Matsunaka 2001). In Senegal, flooding treatment brought about the same effect as herbicide application or manual weeding (de Vries et al 2010). In the Javanese lowlands, especially in urban areas such as Karawang and Gresik, labor for manual weeding is becoming increasingly scarce because a lot of textile factories and manufactures offer jobs with income amounts that are preferred by young people. Therefore the application of herbicides in the first tillage is widely practiced to kill all weeds that emerged in the time of fallow. The proportion of farmers who used herbicides on their farms was $60 \%$ or more in the lowland areas while less than $15 \%$ in the uplands (Table 1).

Table 1 Characteristics and composition of weeds in paddy fields

\begin{tabular}{|c|c|c|c|c|c|c|}
\hline \multirow{3}{*}{ Parameters } & \multicolumn{6}{|c|}{ District } \\
\hline & \multicolumn{2}{|c|}{ West Java } & \multicolumn{2}{|c|}{ Central of Java } & \multicolumn{2}{|c|}{ East Java } \\
\hline & Cianjur & Karawang & Karanganyar & Brebes & Malang & Gresik \\
\hline $\begin{array}{l}\text { Characteristic of } \\
\text { region }\end{array}$ & Upland & Lowland & Upland & Lowland & Upland & Lowland \\
\hline Herbicide application & & & & & & \\
\hline Manual weeding (\%) & $\begin{array}{l}13.3 \\
71.5\end{array}$ & 60 & $\begin{array}{c}0 \\
100\end{array}$ & 06.1 & $\begin{array}{l}6.7 \\
100\end{array}$ & $\begin{array}{l}00.1 \\
032\end{array}$ \\
\hline $\begin{array}{l}\text { Time of fallow } \\
\text { (weeks) } \\
\text { Weed cover (\%) }\end{array}$ & $3-4$ & $6-10$ & $3-5$ & $3-8$ & $3-4$ & $10-14$ \\
\hline - $\quad$ paddy field & $0-10$ & $0-5$ & $0-12$ & $0-10$ & $0-10$ & $2-15$ \\
\hline - fallow field & $30-80$ & $20-85$ & $50-90$ & $20-75$ & $20-80$ & $40-80$ \\
\hline - bund & $60-90$ & $20-70$ & $65-85$ & $10-80$ & $50-90$ & $60-90$ \\
\hline $\begin{array}{l}\text { Weed biomass source } \\
\text { Number of weed } \\
\text { species on subplots }\end{array}$ & Bund & Fallow & Bund & $\begin{array}{l}\text { Fallow and } \\
\text { bund }\end{array}$ & Bund & $\begin{array}{c}\text { Fallow and } \\
\text { bund }\end{array}$ \\
\hline - $\quad$ on paddy field & $7 \pm 2$ & $9 \pm 3$ & $17 \pm 6$ & $11 \pm 3$ & $16 \pm 3$ & $9 \pm 2$ \\
\hline - on bund & $19 \pm 5$ & $7 \pm 3$ & $20 \pm 4$ & $13 \pm 4$ & $15 \pm 4$ & $17 \pm 5$ \\
\hline
\end{tabular}

Water availability in lowland areas is limited during the dry season. In this period, farmers decide to let their land lie fallow or to plant intermediate crops such as corn, onions, beans, cassava and other drought-resistant plants. Rice cultivation is restricted to the rainy season. This practice influences the weed biomass source in paddy field areas. Weed biomass sources in upland areas were mostly bunds as a result of permanent control in the paddy fields. In contrast, in the lowlands the most important weed biomass sources were fallows (Table 1). Therefore, in upland areas, farmers usually harvest weeds from paddy fields to supply animal 
feed. In lowland areas, farmers usually take their animals to the fallows to let them graze until the afternoon, especially during the dry season.

The dominant weeds used for animal feed are listed in Table 2. It shows that farmer chiefly use grass for ruminant feed which is available on their land. About 15 grass species including Echinochloa spp., Panicum repens L., Cynodon dactylon (L.) Pers., Paspalum spp. and Brachiaria spp. were taken from paddy field areas for ruminant feed.

Previous studies reported that common weeds in the upland paddy fields in West Java were Myriophyllum aquaticum (Vell.) Verdc. and Sagittaria guayanensis Kunth, and in lowland areas Leersia hexandra Sw., Sacciolepis interrupta (Willd.) Stapf and Ipomoea aquatica Forssk. (Yakup 2007), while in central Java in lowland areas Marsilea crenulata Desv., Paspalum distichum L., Echinochloa crus-galli (L.) P.Beauv, Echinochloa glabrescens Munro ex Hook. f. and Fimbristylis miliacea (L.) Vahl were dominant weeds (Soerjandono 2005). The mismatches with our results may be due to the fact that the previous studies were restricted to paddy fields while our research covered paddy fields and bunds.

\section{Weed biomass}

Weed biomass is the most important indicator of feed availability for ruminants in paddy field areas. Weed biomass differed significantly among paddy field areas, with upland areas (Cianjur, Karanganyar and Malang) producing higher biomass values than lowland areas (Karawang, Brebes, Gresik) (Table 3). Fresh weed biomass in the first rice growing season (early rainy season) yielded $891-2369 \mathrm{~g} / \mathrm{m}^{2}$. There were no significant differences between the locations of eastern, central, or western Java, respectively. 
Table 2 Weed taxa encountered as ruminant feed

\begin{tabular}{|c|c|c|c|c|c|c|c|c|}
\hline \multirow[t]{2}{*}{ Family } & \multirow[t]{2}{*}{ Genus/species } & \multirow[t]{2}{*}{ Local name } & \multicolumn{6}{|c|}{ Usage Rate $^{1}$} \\
\hline & & & Cianjur & Karawang & Karanganyar & Brebes & Malang & Gresik \\
\hline Amaranthaceae & Alternanthera spp. & Kremah, Tolot soyah & + & - & + & + & - & - \\
\hline Asteraceae & Grangea maderaspatana (L.) Desf. & Kembang paku konde & - & + & + & - & - & - \\
\hline Asteraceae & Spaeranthus ukumbensis & Brincil, Ki heuleut & - & + & - & - & - & - \\
\hline Boraginaceae & Heliotropium indicum L. & $\begin{array}{l}\text { Sangketan, Uler-uleran } \\
\text { Gewor lalakina, }\end{array}$ & - & + & ++ & ++ & - & - \\
\hline Commelinaceae & Commelina spp. & Brambangan & - & + & + & - & - & - \\
\hline Сyperaceae & Cyperus spp. & Teki & + & - & + & + & + & + \\
\hline Cyperaceae & Fimbristylis spp. & Teki & ++ & ++ & + & ++ & + & - \\
\hline Euphorbiaceae & Phyllanthus spp. & Meniran & + & + & - & + & + & + \\
\hline Fabaceae & Centrosema spp. & Kacang asu, Katropong & - & - & + & - & - & - \\
\hline Fabaceae & Sesbania spp & Turi & - & - & - & - & - & + \\
\hline Linderniaceae & Lindernia spp. & Kerak nasi, Brobos kebo & + & - & + & + & + & + \\
\hline Onagraceae & Ludwigia spp. & Kaloga, Krangkong & + & + & - & - & - & - \\
\hline Poaceae & Axonopus compressus (Sw.) P.Beauv & Jukut pahit, Papaitan & + & - & + & - & + & - \\
\hline Poaceae & Brachiaria spp. & Rayapan, Malela & + & - & + & + & ++ & - \\
\hline Poaceae & Cynodon dactylon (L.) Pers. & Grinting, Jujut kakawatan & ++ & ++ & ++ & + & ++ & - \\
\hline Poaceae & Dactyloctenium aegyptium (L.) Willd. & Jukut tapak jalak & - & - & + & - & - & - \\
\hline Poaceae & Digitaria spp. & Rumput cakar ayam & + & - & + & + & +++ & + \\
\hline Poaceae & Echinochloa spp. & Jajagoan, Suket tuton & + & + & + & + & + & ++ \\
\hline Poaceae & Eleusine indica (L.) Gaertn. & Lulangan, Jukut jampang & - & - & + & + & ++ & - \\
\hline Poaceae & Imperata cylindrica (L.) Raeusch. & Alang-alang & - & - & - & - & + & - \\
\hline Poaceae & Isachne globosa (Thunb.) Kuntze & Kakasuran & - & - & - & + & - & - \\
\hline Poaceae & Leersia hexandra Sw. & Kalamenta, Kolomento & - & - & - & + & - & ++ \\
\hline Poaceae & Leptochloa chinensis (L.) Nees & Bobontengan, Jangkiri & - & - & + & + & - & - \\
\hline Poaceae & Panicum repens L. & Lempuyangan, Jajahean & ++ & + & + & - & + & - \\
\hline Poaceae & Paspalum spp & Paitan, Kinangan & +++ & - & ++ & - & - & + \\
\hline Poaceae & Setaria palmifolia (J.Koenig) Stapf & Juwawut, Rumput palem & ++ & - & - & + & - & - \\
\hline
\end{tabular}

${ }^{1}$ Usage rate: amount of rice weeds in ruminant feed (percentage), i.e: $-=0 \%,+=1-10 \%,++=10-20 \%,+++=>20 \%$ 
Table 3 Biomass and nutrient content of weeds in paddy field areas

District

$\begin{array}{llll}\text { Parameters } & \text { West Java } & \text { Central of Java } & \text { East Java }\end{array}$

\begin{tabular}{lcccccc} 
& Cianjur & Karawang & Karanganyar & Brebes & Malang & Gresik \\
\hline Fresh weight $\left(\mathrm{g} / \mathrm{m}^{2}\right)$ & $2369^{\mathrm{a}}$ & $900^{\mathrm{b}}$ & $1912^{\mathrm{a}}$ & $922^{\mathrm{b}}$ & $2131^{\mathrm{a}}$ & $891^{\mathrm{b}}$ \\
Dry weight $\left(\mathrm{g} / \mathrm{m}^{2}\right)$ & $284^{\mathrm{a}}$ & $140^{\mathrm{b}}$ & $246^{\mathrm{a}}$ & $151^{\mathrm{b}}$ & $258^{\mathrm{a}}$ & $128^{\mathrm{b}}$ \\
Dry matter $(\%)$ & $12.0^{\mathrm{d}}$ & $15.6^{\mathrm{a}}$ & $12.9^{\mathrm{c}}$ & $16.4^{\mathrm{a}}$ & $12.1^{\mathrm{d}}$ & $14.3^{\mathrm{b}}$ \\
\hline
\end{tabular}

${ }^{\mathrm{a}, \mathrm{b}}$ Values within a row with different superscripts differ significantly at $P<0.05$

Fresh weed biomass in Javanese paddy fields differed from that found by Roder et al (1998) who measured 220-990 g/m²/year of fresh weed biomass over the rice growing season in northern Laos, or Baloch et al (2005) who measured 387-919 g/ $\mathrm{m}^{2}$ of dry weed biomass on 2002 in Pakistan. Our results show that the high values of fresh weed biomass have the potential to supply ruminant feed in Java. There are many factors affecting the weed biomass between countries, such as different species, seasonal and climatic variation as well as different farming management systems (Machado et al 2005; Baloch et al 2005). Weed biomass varies between regions and even between small farms in the same village due to differences of environmental factors and farming management (Roder et al 1998).

In the upland, there is natural water supply on paddy fields throughout the year. In the lowlands, most paddy fields were flooded only during the rainy season that begins in the end of September and lasts until March (Meteorology, Climatology \& Geophysics Board 2008). These conditions lead to decreasing soil water content and increasing dry plant matter in lowland areas, especially towards the end of the dry season, because moisture stress might reduce plant growth but generally increases leaf to stem ratios (Linn \& Martin 2012)

The combination of herbicide application and manual weeding in the lowland paddy fields of Karawang, Brebes and Gresik resulted in a significantly higher degree of weed suppression. Soerjandono (2005) reported that herbicide application in the early plantation time has the same effect in reducing the amount of weed as twice manual weeding. Manual weeding is a more effective method to reduce weed populations than herbicide application which might be related to their efficacy on weed, if labor is not a limiting factor (Baloch et al 2005). Herbicide effects on weeds include discoloration and deformation of leaves, growth inhibition and death (Ueji \& Inao 2001). Daud (2008) reported that weeds from rice farming areas are safe for animal feed after about fourteen days after herbicide application.

Variability of surface water condition also affects the growth of rice weed communities (Juraimi et al 2011). Hence, weed biomass in upland areas is concentrated on terraced sites since weeds have been suppressed on about $70 \%$ of the paddy field areas 
through ponding waters. Paddy fields flooded with water until 10-15 cm depth has been found to be effective in the control of Echinochloa crus-galli and other weed species after the rice has been transplanted (Shibayama 2001). In all lowland areas, rice weeds were found to grow mainly in times of fallow and the values were not significantly different from each other.

There were biologically small but statistically significant differences in the comparison of dry matter percentage in each location. In the lowlands higher dry matter values were found than in the uplands. Cutting times and plant structural composition seems to affect weed biomass (Yolcu et al 2006).

\section{Weed nutrient content}

Weed nutrient content information is important for assessing the value of weeds as fodder for animals. The results of weed nutrient analyses are presented in Table 4. In our study we found that their nutrient content qualifies weeds as ruminant feed. Weed nutrient content can be affected by climatic conditions during growth and harvest, especially temperature, light and rainfall (Linn \& Martin 2012). In hot climates weed will have a lower digestibility than weed growing in cooler climates even with identical crude protein contents (Mtui et al 2009).

Table 4 Nutrient content of weeds in the studied paddy field areas on dry matter basis (\%)

\begin{tabular}{|c|c|c|c|c|c|c|}
\hline \multirow{3}{*}{ Parameters } & \multicolumn{6}{|c|}{ Districts } \\
\hline & \multicolumn{2}{|c|}{ West Java } & \multicolumn{2}{|c|}{ Central of Java } & \multicolumn{2}{|c|}{ East Java } \\
\hline & Cianjur & Karawang & Karanganyar & Brebes & Malang & Gresik \\
\hline Ash & 15.8 & 13.7 & 13.7 & 25.1 & 14.7 & 13.3 \\
\hline Crude protein & 17.9 & 12.6 & 13.6 & 17.4 & 13.4 & 14.9 \\
\hline Crude fiber & 39.4 & 42.2 & 41.2 & 34.1 & 38.7 & 42.1 \\
\hline NDF & 93.5 & 88.2 & 87.4 & 68.4 & 72.9 & 78.8 \\
\hline $\mathrm{ADF}$ & 57.5 & 44.2 & 78.7 & 62.7 & 68.8 & 60.2 \\
\hline Crude fat & 1.1 & 1.2 & 1.1 & 0.9 & 0.8 & 1.1 \\
\hline $\mathrm{Ca}$ & 0.57 & 0.55 & 0.87 & 2.97 & 0.52 & 1.43 \\
\hline $\mathrm{P}$ & 0.25 & 0.27 & 0.33 & 0.38 & 0.32 & 0.40 \\
\hline Gross energy (kal/g) & 4597 & 4298 & 4315 & 3570 & 4463 & 4597 \\
\hline
\end{tabular}

Protein is the most limiting nutrient for ruminant productivity. Protein content of forage is influenced by species, relative maturity and the proportion of leaves (Ball et al 2005). In our study, the weeds examined were mostly young grasses harvested at about 25-30 days of age. The percentage of crude protein was found to range between 12.6-17.9\% (Table 4), considerable amounts compared to that of native grasses (5-8\%; ACIAR 2009) or to forage 
from a natural grassland in Poso, Java (6.31-6.63\%; Damry 2009). This means that the crude protein content of the weeds in paddy field areas is sufficient for the maintenance of ruminants because our findings lie beyond a critical value of about $10 \%$ crude proteins required for feed digestibility (Leng 1990).

The protein content is also affected by environmental factors such as season, area, sampling site (Miraglia et al 2008), water and soil nutrients (Sigua et al 2012). In Java, the crude protein content varied among locations, with the highest crude protein values in Cianjur and Brebes. The lowest crude protein content in Karawang may be due to the fact that a few sites in Karawang were studied in the dry season. Water supply affected crude protein content because grasses have less actively growing shoots and smaller proportion of leaves with higher stem to leaf ratios (Hughes et al 2011). Fertilizer application on paddy field could increase weed nutrient content. Sigua et al (2012) reported that flooding duration and level of fertilization have varied effects on crude protein.

Other weeds representing potential feed resources could be utilized to avoid protein deficiency which reduces the overall performance of the animals (Mtui et al 2009). Especially leguminous weeds, such as Centrosema spp. and Sesbania spp., may be used as protein supplement to counteract nitrogen deficiency of ruminant animals fed on poor quality feed. In this study, only farmers from Karanganyar and Gresik harvested leguminous weeds from their paddy fields as fodder for the animals, albeit in small proportion.

Our study showed the level of different fiber fractions. Crude fiber content was found equal in each plot, but neutral detergent fiber (NDF) and acid detergent fibre (ADF) content differed. NDF and ADF content in upland areas were higher than in lowland areas (Table 4). This could be a result of more rapid plant maturity causing lignification (Van Soest et al 1991) due to higher temperatures and severe moisture stress.

\section{Acknowledgements}

This paper is an output from field research carried out thanks to Erasmus Mundus Experts Asia (mobility program) and funded by BIOTROP (PhD grant 2012). We are grateful to Dr. Soekisman Tjitrosoedirdjo for useful comments on the proposal and Dr. Sri S. Tjitrosoedirdjo for every support of our field work and laboratory research. 


\section{References}

ACIAR. 2009. Strategies to increase growth of weaned Bali calves. Australian Centre for International Agricultural Research. Canberra. Final Report No. FR2009-24. 33pp.

Ball, D., M. Collins, G. Lacefield, N. Martin, D. Mertens, K. Olson, D. Putnam, D. Undersander and M. Wolf. 2005. Understanding forage quality. Available at http://animalrangeextension.montana.edu/attachments/UnderstandingForageQuality.pdf (last accessed on 12 June 2013)

Baloch, M.S., G. Hassan and T. Morimoto. 2005. Weeding techniques in transplanted and direct wet-seeded rice in Pakistan. Weed Biology and Management. 5. 190-196.

Bappenas (National Development Planning Board) 2003 Luas panen, produktivitas dan produksi padi di Indonesia (GKG) [Harvested area, productivity and rice production in Indonesia]. Available at http://www.bappenas.go.id/unit-kerja/deputi-bidang-sumberdaya-alam-dan-lingkungan-hidup/direktorat-pangan-dan-pertanian/luas-panenproduktivitas-dan-produksi-padi-indonesia-gkg/?\&kid=1390384257 (last accessed on 10 April 2013)

Chin, D.V., T.T.N. Son, C.V. Hach, K. Itoh and H. Hiraoka. 2000. Collection and identification of lowland rice weeds. Research report, JIRCAS, Ibaraki, Japan. pp. 101106.

Damry, D. 2009. Production and nutrients composition of forages produced from a natural grassland in Lore Utara subdistrict, Poso District. Jurnal Agroland. 16. 296-300.

Daud, D. 2008. Uji efikasi herbisida glifosat, sulfosat dan paraquat pada sistem tanpa olah tanah (TOT) jagung [Efficacy test of glyphosate, sulphosate, and paraquat herbicide on no tillage system of corn]. In Proceedings of Seminar Ilmiah dan Pertemuan Tahunan PEI PFI XIX Komisariat Daerah Sulawesi Selatan, 5 November 2008, Sulawesi Selatan. pp. 316-327.

de Vries, M.E., J. Rodenburg, B.V. Bado, A. Sow, P.A. Leffelaar and K.E. Giler. 2010. Rice production with less irrigation water is possible in a Sahelian environment. Field Crops Research. 116. 154-164.

Goering, H.K. and P.J. Van Soest. 1970. Forage fiber analyses (apparatus, reagents, procedures, and some applications). Agriculture handbook, 379. Agriculture Research Service United States Department of Agriculture, Washington DC. pp. 8-12. 
Hughes, M.P., P.G.A. Jennings, V. Mlambo and C.H.O. Lallo. 2011. Exploring seasonal variations in sward characteristics and nutritive value of tropical pastures grazed by beef and dairy cattle on commercial farms in Jamaica. Journal of Animal Science Advances. 1. 47-60.

Juraimi, A.S., A.H.M. Saiful, M.K. Uddin, A.R. Anuar and M. Azmi. 2011. Diversity of weed communities under different water regimes in bertram irrigated direct sedded rice field. Australian Journal of Crop Science. 5. 595-604.

Leng, R.A. 1990. Factors affecting the utilization of 'poor quality' forages by ruminants particularly under tropical condition. Nutrition Research Reviews. 3. 277-303.

Linn, J.G. and N.P. Martin. 2012. Forage quality test and interpretations. Available at www.extension.umn.edu/distribution/livestocksystems/Dl2637.html (last accessed on 08 April 2013)

Machado, C.F., S.T. Morris, J. Hodgson and M. Fathalla. 2005. Seasonal changes of herbage quality within a New Zealand beef cattle finishing pasture. New Zealand Journal of Agriculture Research. 48. 265-270.

Matsunaka, S. 2001. Historical review of rice herbicides in Japan. Weed Biology and Management. 1. 10-14

Meteorology, Climatology and Geophysics Board. 2008. Temperature, Rainfall, and Humidity. Field observation data. Bogor. Indonesia.

Miraglia, N., M. Constantini, M. Polidori, G. Meineri and P.G. Peiretti. 2008. Exploitation of a natural pasture by wild horses: comparison between nutritive characteristics of the land and the nutrient requirements of the herds over a 2-year period. Animal. 2. 410418.

Mtui, D.J., P.F. Lekule, N.M. Shem, T. Ichinohe and T. Fujihara. 2009. Comparative potential nutritive value of grasses, creeping legumes and multipurpose trees commonly in sub humid region in the Eastern parts of Tanzania. Livestock Research for Rural Development. 21. 158

Nyarko, K.A. and S.K.D. Datta. 1993. Effects of light and nitrogen and their interaction on the dynamics of rice-weed competition. Weed Research. 33. 1-8.

Roder, W., B. Keoboulapha, S. Phengchanh, J.C. Prot and D. Matias. 1998. Effect of residue management and fallow length on weeds and rice yield. Weed Research. 38. 167-174. Shibayama, H. 2001. Review: Weed and weed management in rice production in Japan. Weed Biology and Management. 1. 53-60. 
Sigua, G.C., M. Williams, J. Grabowski, C. Chase and M. Kongchum. 2012. Effect of flooding duration and nitrogen fertilization on yield and protein content of three forage species. Agronomy Journal. 104. 791-798.

Soerjandono, N.B. 2005. Teknik pengendalian gulma dengan herbisida persistensi rendah pada tanaman padi. Buletin Teknik Pertanian. 10. 5-8.

Soerjani, M., A.J.G.H. Kostermans and G. Tjitrosoepomo. 1987. Weeds of rice in Indonesia. Jakarta. Balai Pustaka. 716 pp.

Ueji, M. and K. Inao. 2001. Review: Rice paddy field herbicides and their effects on the environment and ecosystems. Weed Biology and Management. 1. 71-79

Ulber, L. 2010. Weed species diversity in cropping systems: Management and conservation strategies. PhD Thesis. Georg-August-Universität Göttingen, Göttingen. Germany. 170 pp.

Van Soest, P.J., J.B. Robertson and B.A. Lewis. 1991. Methods for dietary fibre, neutral detergent fibre and non-starch polysaccharides in relation to animal nutrition. Journal Dairy Science. 74. 3583-3597.

Yakup. 2007. Study on spatio-temporal dynamics of weed communities in rice field landscape of Ciliwung-Cisadane watershed. PhD Thesis. Bogor Agricultural University (IPB). Bogor. Indonesia. 130pp.

Yolcu, H., M. Tan and Y. Serin. 2006. Effects of early cutting time and stubble height on yield and quality in lucerne. New Zealand Journal of Agricultural Research. 49. 201206. 


\section{Synthesis}

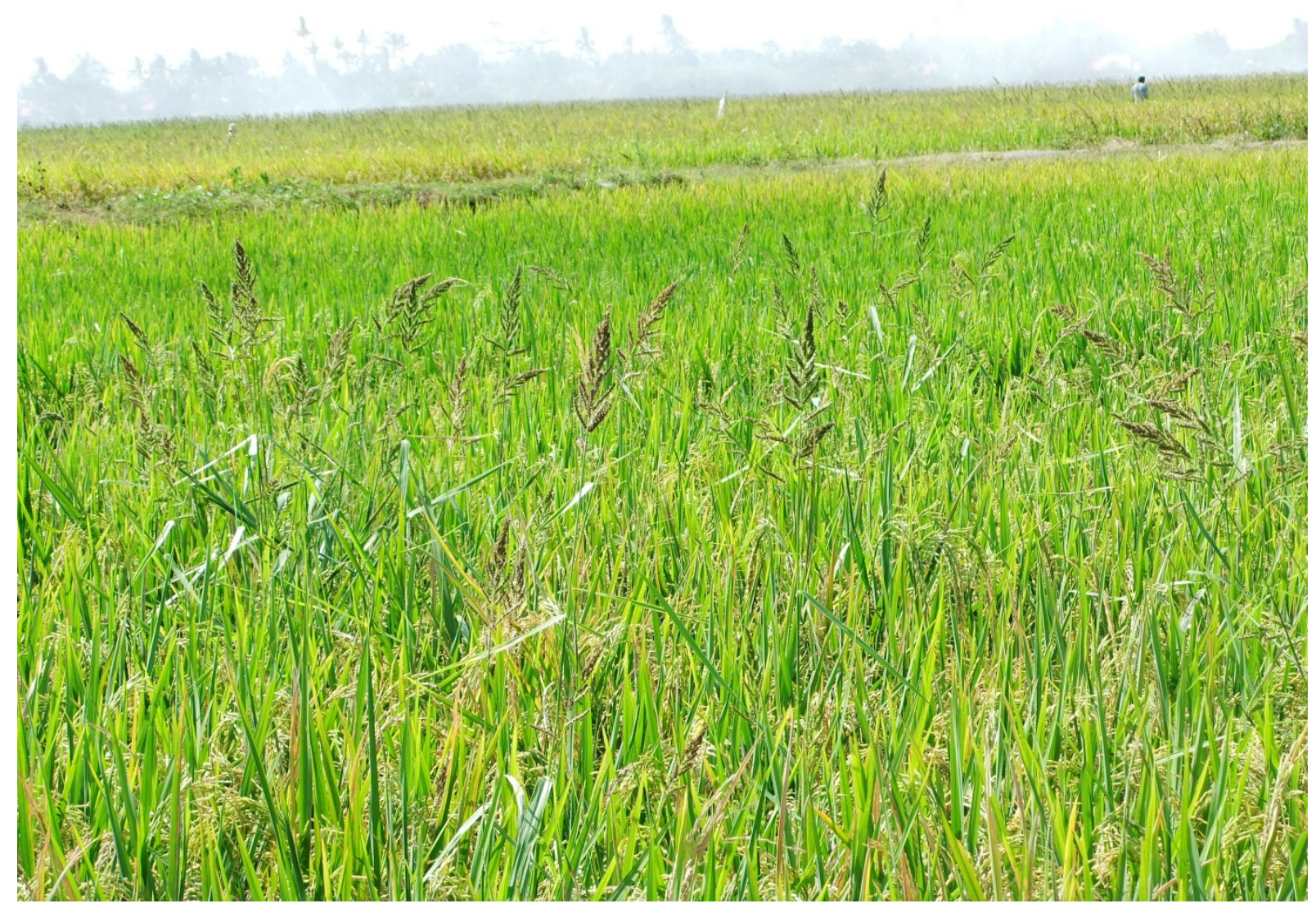




\section{Diversity ecosystem structure and agriculture management in Java paddy field}

In chapter 1 I reviewed a number of studies about ecosystem structure and agriculture management in paddy field in relation to environment, plant species richness and communities that were discussed in the research study. This chapter showed that ecosystem diversity in paddy fields is varied related to the environmental conditions in each area. Thus it is intriguing to find evidence for environmental complexity effects in the paddy field, in spite of the great variety of other environmental factors simultaneously acting on plant communities.

The review resulted that the supply and control of water is crucial to rice production systems and agriculture management. Based on water regime, there are four main rice agriculture systems, i.e.: irrigated paddy field, rainfed paddy field, dry paddy field and tidal swamp paddy fields (Soerjani et al. 1987). The studies focused on irrigated paddy fields that have dominated rice agriculture systems in Java. Irrigated paddy field cover more than 70 percent of rice production systems and yield the greatest level of productivity. In paddy fields, most plant species are considered undesirable and as serious biological competitors to the rice plants. Therefore, weed control is an essential component in rice agriculture management.

\section{Species diversity in paddy field under varied environment and agronomic practices}

Chapter II revealed that weed species cover and diversity are affected by agronomic practices and differ between environments. Floristically, the studied paddy field areas are largely composed of Poaceae (23.2\%), Asteraceae (14.0\%), Rubiaceae (4.8\%) and Fabaceae (4.3\%). In this study, six different classes were classified related to water availability, cultivation status, and water level. Further, weed diversity in mid elevation fields is higher than in many of the lowland paddy fields due to the farmers' preference in lowland area to control weed by herbicide application in the dry season.

The different weed species pool size is emphasized on the local and plot level by effects of agricultural management, especially cultivation time and weeding habits. Cultivation time related with water level in paddy fields depends on the amount and periodicity of rainfall. Water level affects the weed diversity, inhibits the germination of certain weed seeds (Tomita et al., 2003) and suppresses grass growth (Juarimi et al., 2011). High water level in paddy field brought the same effects as herbicide application and manual weeding (De Vries et al., 2010). 


\section{Species diversity in paddy field under differ surrounding crop and semi natural vegetation}

Chapter III about study on surrounding crop characteristics in the paddy fields showed that crop diversity is positively influencing the weed species diversity. Intercropping around paddy fields and on bunds was correlated with an increase of weed species number due to positive effects on organic carbon, soil nitrogen, some micronutrients (Prasad and Umar, 1990), total nutrients and nutrient uptake (Mohammaddoust-e-Chamanabad et al., 2007). The highest weed species number was found in fallow fields with complex landscape and bunds in Cugenang or Malang in the first season. In contrast, the semi-natural vegetation surrounding paddy fields was unrelated to weed species number.

\section{Species diversity an opportunity for the integrated farming system}

High diversity in paddy fields has several advantages for Javanese farmer such as pest trap and ruminant feed. In the chapter IV I showed that plant diversity in paddy field had a high potential to increase the utilization of weeds in paddy field as ruminant feed. However, weed biomass and nutrient varies between regions, especially along gradient sites. Weed nutrient content can be affected by climatic conditions during growth and harvest (Linn \& Martin 2012); environmental factors such as season, area, sampling site (Miraglia et al 2008), water and soil nutrients (Baloch et al 2005); and agricultural management, such as herbicide application (Ueji \& Inao 2001), fertilizer application and flooding (Sigua et al 2012).

In conclusion, varied environment in paddy field, surrounding crop are linked and both are related to community characteristics of weed species. Therefore, the maintenance of a diverse weed can help to support integrated farming system as ruminant feed.

Further, some effects differed between region which shows the importance of conducting observations or experiments in varied region to be able to draw more general conclusions or to map weed diversity in Java. 


\section{References}

Baloch, M.S., G. Hassan and T. Morimoto. 2005. Weeding techniques in transplanted and direct wet-seeded rice in Pakistan. Weed Biology and Management. 5. 190-196

de Vries, M.E., J. Rodenburg, B.V. Bado, A. Sow, P.A. Leffelaar and K.E. Giler. 2010. Rice production with less irrigation water is possible in a Sahelian environment. Field Crops Research. 116. 154-164

Juraimi, A.S., A.H.M. Saiful, M.K. Uddin, A.R. Anuar and M. Azmi. 2011. Diversity of weed communities under different water regimes in bertam irrigated direct seeded rice field. Australian Journal of Crop Science. 5 (5). 595-604

Linn, J.G. and N.P. Martin. 2012. Forage quality test and interpretations. Available at www.extension.umn.edu/distribution/livestocksystems/Dl2637.html (last accessed on 08 April 2013)

Miraglia, N., M. Constantini, M. Polidori, G. Meineri and P.G. Peiretti. 2008. Exploitation of a natural pasture by wild horses: comparison between nutritive characteristics of the land and the nutrient requirements of the herds over a 2-year period. Animal. 2. 410418

Mohammaddoust-e-Chamanabad, H.R., A. Asghari and A.M. Tulikov. 2007. The effects of weed-crop competition on nutrient uptake as affected by crop rotation and fertilizers. Pakistan Journal of Biological Sciences. 10 (22). 4128-4131

Prasad, B. and S.M. Umar. 1990. Effect of rice based six multiple cropping sequences under two cycles of crop rotations on yield and fertility status of soil. Plant and Soil. 127. 251-258

Sigua, G.C., M. Williams, J. Grabowski, C. Chase and M. Kongchum. 2012. Effect of flooding duration and nitrogen fertilization on yield and protein content of three forage species. Agronomy Journal. 104. 791-798

Soerjani, M., A.J.G.H. Kostermans and G. Tjitrosoepomo. 1987. Weeds of rice in Indonesia. Jakarta. Balai Pustaka. 716 pp

Tomita, S., S. Miyagawa, Y. Kono, C. Noichana, T. Inamura, Y. Nagata, A. Sributta and E. Nawata. 2003. Rice yield losses by competition with weeds in rainfed paddy fields in north-east Thailand. Weed Biology and Management. 3. 162-171

Ueji, M. and K. Inao. 2001. Review: Rice paddy field herbicides and their effects on the environment and ecosystems. Weed Biology and Management. 1. 71-79 


\section{Acknowledgements}

I would like to thank the numerous people who kindly supported and helped me in realizing my study and accomplishing this $\mathrm{PhD}$ thesis.

First of all, I want to thank Prof. Erwin Bergmeier and Prof. Hermann Behling, who gave me the opportunity to independently work on my study constructive suggestions, and provide many valuable ideas and insights during scientific discussions, and for always being such positive and supportive supervisors.

My special thanks also go to the members of examination committee: Prof. Markus Hauck, Prof. Christoph Leuchner, Prof. Johannes Isselstein and Prof. Susanne Bögeholz for their detailed review and positive comments to this dissertation.

I want to acknowledge with gratitude my promoter, Dr. Heike Culmsee, who has been a great support for my study, valuable comments on my proposal and especially for your trust.

I would like to express many thank to Prof. Luki Abdullah for suggestion, interesting discussions and helpful advice in various areas, also administration and network support.

Furthermore, I would like to express my gratitude to Dr. Sri Soedarmijati for her valuable comments, suggestions, support and supervise me during laboratory works.

A special gratitude address to the Erasmus Mundus Expertasia I for the financial support during the study period.

The financial fund of the Seameo Biotrop through the PhD grant 2012 for my field work, plant observation, analyzing soil and laboratory works are highly appreciated.

I was not able to conduct all this work by myself and therefore I want to thank: Imam Mawardi for help in the field, his valuable help with sorting and identifying plant samples.

I want to thank Charlotte Seifert, Oliver Fried, and Parastoo Mahdavi for patiently sharing an office with me. Particular thanks to Inga and Florian who was extremely helpful with all analyses matters and always had a friendly word. Thanks to all staff members and friends at the Department of Vegetationsanalyse \& Phytodiversität who helped me in one way or another. 
A very big "thank you” goes to the Indonesian Student Communities in PPI Göttingen, for all of you who helped to create a wonderful and friendly studying atmosphere and I will miss you all.

Special thanks go to to my parents, Rochmani Subagyono and Rochmah, to my sister and brother, Dwi Prihatni Amrih Rahayuningtyas and Putut Suryo Negoro, who all have been a great support during the years.

Finally, the heartfelt thanks go to my beloved husband, Sunardi, and my sons, Hafiz Kanz Ardi Raharjo and Nibras Kanz Abdillah, for giving me the opportunity to study, for their constant supports, for their faith, patience and for their love. 


\section{Declaration of originality and certificate of ownership}

I, Nur Rochmah Kumalasari, hereby declare that I am the sole author of this dissertation entitled "Diversity of rice weeds vegetation and its potential as local forage resource in Java, Indonesia". All the references and data sources that were used in this dissertation have been appropriately acknowledged. I furthermore declare that this work has not been submitted elsewhere in any form as part of another dissertation procedure.

Göttingen, June 2014

(Nur Rochmah Kumalasari) 


\section{Curriculum Vitae}

NUR ROCHMAH KUMALASARI

\section{Personal information}

Nationality

Date of Birth

Place of Birth

Occupation

\section{Education Background}

2011 - now

$2004-2006$

$1999-2003$

\section{Research Experiences}

2011-2012

2010

2010

2008

2006

2004
Indonesian

14 February 1981

Kebumen

Junior lecturer and researcher on Department of Nutrition and Feed Technology, Faculty of Animal Science, Bogor Agricultural University

$\mathrm{PhD}$ candidate of

Department of Vegetation and Phytodiversity Analysis, Albrecht-vonHaller Institute of Plant Sciences, Georg-August University of Göttingen

Magister Science on Study Program of Management of Nature Resources and

Environment

Major: Biodiversity and Ecotourism

Bogor Agricultural University

Bachelor from Department Animal Nutrition and Feed

Major: Pasture and Forage Science

Bogor Agricultural University, Bogor, Indonesia

Weed diversity and communities in paddy field in Java Island

Product development of hay, powder and pellet of Indigofera cordifolia leaves as protein source alternative for dairy goats feed

Production of corn plant waste biscuit as ruminant commercial feed

Production and nutrient analysis of corn forage 15 days age as concentrate substitution for feed efficien-cy on calves maintenance

Analysis of the effect alien species Acacia nilotica Willd. Ex. Dell 1813 on banteng movement pattern (Bos javanicus d'Alton 1823) at Bekol Savanna, Baluran National Park

The effect of Chromolaena odorata Mulch on Zea mays forage productivity planted at Latosol 


\section{Scientific writing}

Kumalasari, N.R., L. Abdullah and E. Bergmeier. 2014. Nutrient assessment of paddy weeds as ruminant feed in Java. Livestock Research for Rural Development. 26: 59. http://www.lrrd.org/lrrd26/4/kuma26059.html

Kumalasari, N.R., E. Bergmeier and L. Abdullah. 2012. Diversity and potency of weed on rice field for ruminant feed in Java. Proceeding of the $2^{\text {nd }}$ International Seminar on Animal Industry. Jakarta

Abdullah, L. and N.R. Kumalasari. 2011. Amino acid contents of Indigofera arrecta leaves after application of foliar fertilizer. Journal of Agricultural Science and Technology A. 1. 1224-1227

Retnani Y., I. Wijayanti, and N.R. Kumalasari. 2010. Produksi Biskuit Limbah Tanaman Jagung Sebagai Pakan Komersil Ternak Ruminansia. Jurnal Ilmu Pertanian Indonesia. 16 (1)

Kumalasari, N.R., L. Khotidjah, L. Pane and R. Maelany. 2009. Analysis of young corn herbage production and nutrient as concentrate alternative for feed efficiency at calves maintenance. Proceeding of the $1^{\text {st }}$ International Seminar on Animal Industry. Bogor

Kumalasari, N.R., A. Indrawan and A. Sunkar. 2007. Modeling of impact Acacia nilotica Wild ex.Dell invasion on banteng movement pattern in Bekol savanna. Proceeding of the $2^{\text {nd }}$ International Symposium of Food Security, Nature Conservation and Agricultural. Bogor

Kumalasari, N.R., L. Abdullah, and S. Jayadi. 2005. The effect of Chromolaena odorata L. Kings and Robinson mulch on growth and productivity of corn forage (Zea mays L.) planted at latosol. Journal of Media Peternakan

Abdullah L, A. Setiana and N.R. Kumalasari. 2004. Impact of global warming on farming productivity. National Seminar of Livestock Development 2004. Bogor 